UNIVERSIDADE DE SÃO PAULO

ESCOLA DE ENGENHARIA DE SÃO CARLOS

DEPARTAMENTO DE HIDRÁULICA E SANEAMENTO

REMOÇÃO DE ATIVIDADE ESTROGÊNICA DO HORMÔNIO

17ß-ESTRADIOL EM PROCESSOS DE OXIDAÇÃO DE ÁGUAS PARA ABASTECIMENTO

PAULO ROGÉRIO MARTINS DA SILVA

-VERSÃO CORRIGIDA-

SÃO CARLOS

2013 

UNIVERSIDADE DE SÃO PAULO

ESCOLA DE ENGENHARIA DE SÃO CARLOS

PAULO ROGÉRIO MARTINS DA SILVA

\section{REMOÇÃO DE ATIVIDADE ESTROGÊNICA DO HORMÔNIO 17ß-ESTRADIOL EM PROCESSOS DE OXIDAÇÃO DE ÁGUAS PARA ABASTECIMENTO}

Dissertação apresentada ao Departamento de Engenharia Hidráulica e Saneamento da Escola de Engenharia de São Carlos Universidade de São Paulo para obtenção do título de Mestre em Ciências (Engenharia Hidráulica e Saneamento).

Orientador: Prof. Dr. Luiz Antônio Daniel

São Carlos

2013 
AUTORIZO A REPRODUÇÃO TOTAL OU PARCIAL DESTE TRABALHO, POR QUALQUER MEIO CONVENCIONAL OU ELETRONNICO, PARA FINS DE ESTUDO E PESQUISA, DESDE QUE CITADA A FONTE.

Dissertação (Mestrado) - Programa de Pós-Graduação e Área de Concentração em Hidráulica e Saneamento -Escola de Engenharia de São Carlos da Universidade de São Paulo, 2013.

1. 17b-Estradiol. 2. Ozônio. 3. Cloro. 4. Atividade Estrogênica. 5. BLYES. I. Título. 
Candidato: Bacharel PAULO ROGÉRIO MARTINS DA SILVA.

Título da dissertação: "Remoção de atividade estrogênica do hormônio $17 \beta$ estradiol em processos de desinfecção de águas para abastecimento".

Data da defesa: 25/10/2013

Comissão Julgadora:

Prof. Dr. Luiz Antonio Daniel (Orientador)

(Escola de Engenharia de São Carlos/EESC)

Profa. Dra. Lyda Patrícia Sabogal Paz

(Escola de Engenharia de São Carlos/EESC)

Dr. Gilson Alves Quináglia

(Companhia Ambiental do Estado de São Paulo/CETESB) $\underline{\text { Resultado: }}$

APronso

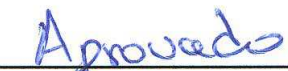

ARROUAOO

Coordenadora do Programa de Pós-Graduação em Engenharia Hidráulica e Saneamento:

Profa. Associada Maria Bernadete A. Varesche Silva

Presidente da Comissão de Pós-Graduação:

Prof. Titular Denis Vinicius Coury 

DEDICATÓRIA

À minha família, amigos e a todos que contribuíram direta ou indiretamente no desenvolvimento deste trabalho. 



\section{AGRADECIMENTOS}

A toda minha família, em especial meu pai Jarbas, minha mãe Valquíria, minha irmã Raquel e meu irmão Ricardo, que a tudo devo nesta vida.

Ao Departamento de Hidráulica e Saneamento da EESC - USP.

À Companhia Ambiental do Estado de São Paulo (CETESB), especialmente à Agência Ambiental de Paulínia (CJU), onde considero uma família e tive o prazer de conhecer pessoas especiais, como a Vera, Lúcio, Carol, Eduardo, Ricardo, Ana, Maria, Rita, Marcos, Villa, Hélio, Cabral, Degrecci, Cibele, Daniela, Sanderson, Francisco, Avany, Mara, Ana Clélia, Patrícia, Eliana e todos os demais terceirizados e estagiários que convivo diariamente ou já trabalhei com muita alegria, e ao Setor de Análises Toxicológicas da CETESB (ELTA), que conduziu por meio do Gilson, Daniela e Rúbia as análises por BLYES.

Ao Serviço Autônomo de Água e Esgoto (SAAE) de São Carlos, pela disponibilização de amostras de água da ETA Centro, e em especial à Eliana, Carlos, Flávio, Renata C., Renata, K. Sr. Luiz e Fernando, pela amizade, e a todos os demais funcionários e amigos com quem trabalhamos juntos por mais de um ano.

À Sociedade de Abastecimento de Água e Saneamento S/A (SANASA), pela disponibilização de amostras de água das ETAs 3 e 4, e especialmente aos amigos André, Rogério, João e Ana, por todos os ensinamentos e inicialização profissional e principalmente que, mesmo após anos de conclusão de estágio, a amizade continua.

Ao Prof. Dr. Luiz Antônio Daniel, pela orientação, paciência, compreensão e amizade de longa data.

À Profa. Eny Maria Vieira, pela disponibilidade de ensaios futuros e na qualificação deste trabalho.

Aos amigos e colegas do Programa de Pós Graduação do SHS, pela amizade, companhia e alegrias. Agradeço, em especial, à Andreza Bortoloti, pela amizade, tutela, orientação e imensurável ajuda na realização deste trabalho, e aos amigos Bruno Pessotto, Rudner Sapla, 
Narumi Abe, Samuel Aquino, Gabriela Palhuzi, Marcos Schaff, Lucas Marcon e todos os demais com quem compartilhei alegrias.

Aos amigos, de longa data de Campinas, especialmente Wesley Costola, Antônio Longhi, André Simionatto, aos amigos do Futebol de Terça e a todos os Cozidos, pela amizade incondicional e sem limites.

Aos colegas e amigos do LATAR, em especial à Maria Teresa Hoffman, por todo auxílio, colaboração e companhia desde o preparo dos reagentes até as análises.

Aos amigos da UNICAMP, especialmente à Gisele, Saulo, Natália, Dani, Fábio onde a amizade persiste através do tempo e distância.

Aos demais não relacionados aqui que contribuíram, de maneira direta ou indireta, em minha formação profissional e pessoal. 


\section{RESUMO}

SILVA, P. R. M. DA. Remoção de atividade estrogênica do hormônio 17ß-estradiol em processos de oxidação de águas para abastecimento. 2013. 98 p. Dissertação (Mestrado) Escola de Engenharia de São Carlos, Universidade de São Paulo, São Carlos, 2013.

Muitos oxidantes químicos reativos acarretam na ruptura de estruturas moleculares complexas de vários tipos de compostos orgânicos decompondo-as em estruturas mais simples e propiciando condições melhores para uma efetiva ação de micro-organismos na degradação biológica. A presença de hormônios, entre eles o 17ß-estradiol, em estações de tratamento de esgoto e em águas subterrâneas e superficiais mostra a necessidade de uma avaliação dos processos de tratamento convencionais. $\mathrm{O}$ objetivo deste trabalho foi a análise e remoção de hormônios através de técnicas de cloração e ozonização de amostras reais de águas de saída de filtro de estações de tratamento de água (ETAs), operadas pelo Serviço Autônomo de Água e Esgoto (SAAE) de São Carlos (ETA Centro), que capta águas dos ribeirão Feijão e córrego Espraiado e pela Sociedade de Abastecimento de Água e Saneamento S/A (SANASA) de Campinas (ETAs 3 e 4), que capta águas do rio Atibaia. Foram realizados ensaios contaminando-se as amostras com $17 \beta$-estradiol, que é o hormônio natural mais presente no meio ambiente, em concentração de $6.000 \mathrm{ng} \mathrm{L}^{-1}$, submetendo-se tratamento com dosagens em torno de 0,5 e $2,0 \mathrm{mg} \mathrm{L}^{-1}$ desses oxidantes, em tempos de contato de, respectivamente, 10 e 30 min. As amostras submetidas à contaminação e tratamento e as de controle (sem contaminação e tratamento) foram analisadas através da remoção do $17 \beta$-estradiol com a verificação da atividade estrogênica das amostras por ensaios de Sistema de Expressão de Estrogênio Induzida por Levedura Bioluminescente (BLYES), que apresentou-se como uma ferramenta simples. Os resultados apresentados neste trabalho demonstram que a oxidação por ozônio se mostrou mais eficiente do que aquela por cloro para a remoção da atividade estrogênica causada, única e exclusivamente, pelo 17 $\beta$-estradiol para uma dosagem inicial desse hormônio relativamente alta $\left(6.000 \mathrm{ng} \mathrm{L}^{-1}\right)$. Todavia, em todos os ensaios a concentração final da atividade estrogênica permaneceu acima do limite de quantificação desses hormônio, indicando que a remoção não foi completa, mesmo em condições favoráveis, isto é, matriz limpa, com padrões de potabilidade para os parâmetros físicoquímicos.

Palavras-chaves: 17ß-Estradiol, Ozônio, Cloro, Atividade Estrogênica, BLYES. 



\begin{abstract}
SILVA, P. R. M. DA. Removal of estrogenic activity of the hormone 17 $\beta$-estradiol in oxidation processes for drinking water. 2013. 98 p. Dissertação (Mestrado) - Escola de Engenharia de São Carlos, Universidade de São Paulo, São Carlos, 2013.
\end{abstract}

Many reactive chemical oxidants cause the disruption of the complex molecular structures of various types of organic compounds decomposing them into simpler structures and providing better conditions for effective action of micro-organisms in the biological degradation. The presence of hormones, including $17 \beta$-estradiol in sewage treatment plants and groundwater and surface water shows the need for an evaluation of conventional treatment processes. The aim of this study was the analysis and removal of hormones through techniques of chlorination and ozonation of real samples of output filter water in water treatment plants (WTP), operated by the Serviço Autônomo de Água e Esgoto (SAAE) of São Carlos (Center WTP), which captures waters from Espraiado stream and Feijão stream and the Sociedade de Abastecimento de Água e Saneamento S/A (SANASA) de Campinas (WTPs 3 and 4), which captures water from the Atibaia river. Assays were performed contaminating the samples with $17 \beta$-estradiol, which is the natural hormone more present in the environment, in a concentration of $6.000 \mathrm{ng} \mathrm{L}^{-1}$ submitting themselves to treatment with dosages of around 0.5 to $2.0 \mathrm{mg} \mathrm{L}^{-1}$ of these oxidants in times of contact, respectively, 10 and $30 \mathrm{~min}$. The samples subjected to contamination and treatment and control samples (without contamination and treatment) were analyzed by removing $17 \beta$-estradiol with estrogenic activity verification of the samples by Bioluminescent Assays or Estrogen-Inducible Yeast Expression System (BLYES), which was presented as a simple tool. The results presented here demonstrate that the oxidation by ozone was more effective than with chlorine to remove estrogenic activity caused solely by $17 \beta$-estradiol for an initial dosage of the hormone relatively high (6000 $n g L^{-1}$ ) However, in all experiments the final concentration of estrogenic activity remained above the limit of quantification of these hormones, indicating that removal was not complete, even under favorable conditions, clean matrix with quality for drinking water physicochemical parameters.

Keywords: 17ß-Estradiol, Ozone, Chlorine, Estrogenic Activity, BLYES. 



\section{LISTA DE FIGURAS}

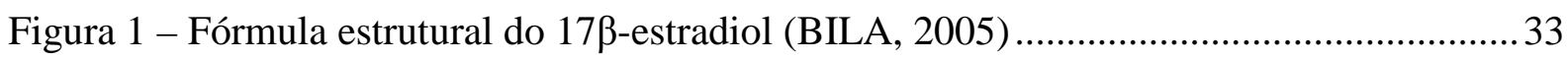

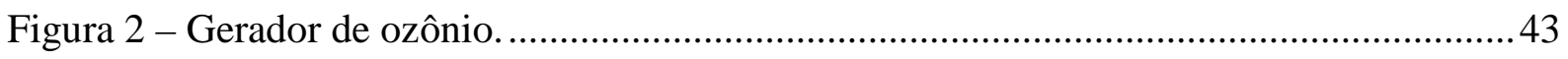

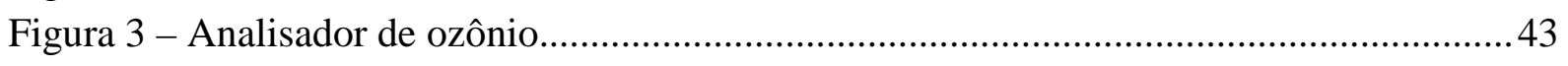

Figura 4 - Unidade de ozonização. ............................................................................. 44

Figura 5 - Cartucho e principais etapas empregadas em EFS (Adaptado de Araújo, 2006).... 48

Figura 6 - Sistema de extração/eluição. .............................................................................. 48

Figura 7 - Esquema da metodologia analítica utilizada na extração da amostra em EFS. ...... 49

Figura 8 - Mapa da microplaca indicando a distribuição dos controles, amostras e padrão de

E2 no ensaio BLYES (adaptado de ELDRIDGE et al., 2011)......................................53

Figura 9 - Processos de expressão e detecção de luminescência do teste BLYES

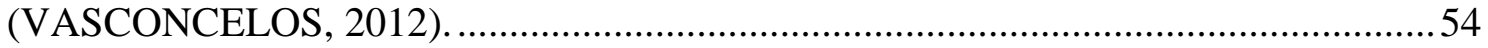

Figura 10 - Gráfico retirado de Fisher (2013), ilustrando os pontos utilizados para o cálculo

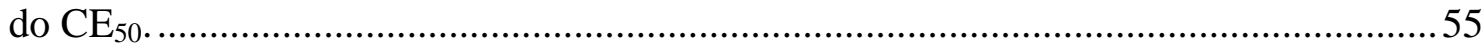

Figura 11 - Curva dose-resposta de 17 $\beta$-estradiol (intensidade de bioluminescência versus concentração molar) para a batelada de análise de amostras tratadas com cloro.............63

Figura 12 - Curva dose-resposta para o Branco da amostra $\mathrm{SC} \mathrm{Cl}_{2}$ (intensidade de bioluminescência versus fator de concentração) para análise de amostras de São Carlos

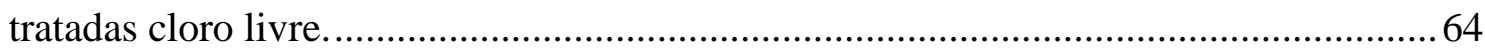

Figura 13 - Curva dose-resposta da amostra $\mathrm{SC} \mathrm{Cl}_{2} 1$ (intensidade de bioluminescência versus fator de concentração) - $1^{\text {a }}$ replicata da amostra de São Carlos com menores tempo de contato concentração de cloro livre.

Figura 14 - Curva dose-resposta da amostra $\mathrm{SC} \mathrm{Cl}_{2} 2$ (intensidade de bioluminescência versus fator de concentração) - $2^{a}$ replicata da amostra de São Carlos com menores tempo de contato concentração de cloro livre.

Figura 15 - Curva dose-resposta da amostra $\mathrm{SC} \mathrm{Cl}_{2} 3$ (intensidade de bioluminescência versus fator de concentração) - $3^{\text {a }}$ replicata da amostra de São Carlos com menores tempo de contato concentração de cloro livre.

Figura 16 - Curva dose-resposta da amostra $\mathrm{SC} \mathrm{Cl}_{2} 4$ (intensidade de bioluminescência versus fator de concentração) - $1^{\text {a }}$ replicata da amostra de São Carlos com maiores tempo de contato concentração de cloro livre.

Figura 17 - Curva dose-resposta da amostra $\mathrm{SC} \mathrm{Cl}_{2} 5$ (intensidade de bioluminescência versus fator de concentração) - $2^{a}$ replicata da amostra de São Carlos com maiores tempo de contato concentração de cloro livre.

Figura 18 - Curva dose-resposta da amostra $\mathrm{SC} \mathrm{Cl}_{2} 4$ (intensidade de bioluminescência versus fator de concentração) - $3^{\text {a }}$ replicata da amostra de São Carlos com maiores tempo de contato concentração de cloro livre.

Figura 19 - Curva dose-resposta para o Branco da amostra CPS $\mathrm{Cl}_{2}$ (intensidade de bioluminescência versus fator de concentração) para análise de amostras de Campinas tratadas cloro livre. 
Figura 20 - Curva dose-resposta da amostra CPS $\mathrm{Cl}_{2} 1$ (intensidade de bioluminescência versus fator de concentração) $-1^{a}$ replicata da amostra de Campinas com menores tempo de contato concentração de cloro livre.

Figura 21 - Curva dose-resposta da amostra CPS $\mathrm{Cl}_{2} 2$ (intensidade de bioluminescência versus fator de concentração) - $2^{\mathrm{a}}$ replicata da amostra de Campinas com menores tempo de contato concentração de cloro livre.

Figura 22 - Curva dose-resposta da amostra CPS $\mathrm{Cl}_{2} 3$ (intensidade de bioluminescência versus fator de concentração) - $3^{\mathrm{a}}$ replicata da amostra de Campinas com menores tempo de contato concentração de cloro livre.

Figura 23 - Curva dose-resposta da amostra CPS $\mathrm{Cl}_{2} 4$ (intensidade de bioluminescência versus fator de concentração) - $1^{a}$ replicata da amostra de Campinas com maiores tempo de contato concentração de cloro livre.

Figura 24 - Curva dose-resposta da amostra CPS $\mathrm{Cl}_{2} 5$ (intensidade de bioluminescência versus fator de concentração) - $2^{\mathrm{a}}$ replicata da amostra de Campinas com maiores tempo de contato concentração de cloro livre.

Figura 25 - Curva dose-resposta da amostra CPS $\mathrm{Cl}_{2} 6$ (intensidade de bioluminescência versus fator de concentração) $-3^{a}$ replicata da amostra de Campinas com maiores tempo de contato concentração de cloro livre.

Figura 26 - Curva dose-resposta de 17 $\beta$-estradiol (intensidade de bioluminescência versus concentração molar) para a batelada de análise de amostras tratadas com ozônio. ....... 77

Figura 27 - Curva dose-resposta para o Branco da amostra $\mathrm{SC} \mathrm{O}_{3}$ (intensidade de bioluminescência versus fator de concentração) para análise de amostras de São Carlos tratadas com ozônio.

Figura 28 - Curva dose-resposta da amostra $\mathrm{SC} \mathrm{O}_{3} 1$ (intensidade de bioluminescência versus fator de concentração) - $1^{a}$ replicata da amostra de São Carlos com menores tempo de contato concentração de ozônio.

Figura 29 - Curva dose-resposta da amostra $\mathrm{SC} \mathrm{O}_{3} 2$ (intensidade de bioluminescência versus fator de concentração) - $2^{\mathrm{a}}$ replicata da amostra de São Carlos com menores tempo de contato concentração de ozônio.

Figura 30 - Curva dose-resposta da amostra $\mathrm{SC} \mathrm{O}_{3} 3$ (intensidade de bioluminescência versus fator de concentração) - $1^{\text {a }}$ replicata da amostra de São Carlos com maiores tempo de contato concentração de ozônio.

Figura 31 - Curva dose-resposta da amostra $\mathrm{SC} \mathrm{O}_{3} 4$ (intensidade de bioluminescência versus fator de concentração) - $2^{\text {a }}$ replicata da amostra de São Carlos com maiores tempo de contato concentração de ozônio.

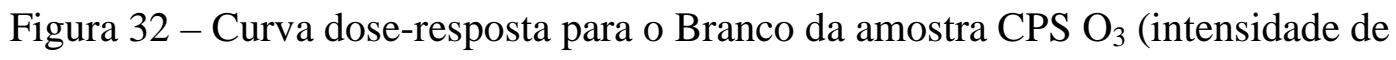
bioluminescência versus fator de concentração) para análise de amostras de Campinas tratadas com ozônio.

Figura 33 - Curva dose-resposta da amostra CPS O $\mathrm{O}_{3} 1$ (intensidade de bioluminescência versus fator de concentração) - $1^{\text {a }}$ replicata da amostra de Campinas com menores tempo de contato concentração de ozônio.

Figura 34 - Curva dose-resposta da amostra CPS O 32 (intensidade de bioluminescência versus fator de concentração) - $2^{\mathrm{a}}$ replicata da amostra de Campinas com menores tempo de contato concentração de ozônio. 
Figura 35 - Curva dose-resposta da amostra CPS $\mathrm{O}_{3} 3$ (intensidade de bioluminescência versus fator de concentração) - $1^{\text {a }}$ replicata da amostra de Campinas com maiores tempo de contato concentração de ozônio.

Figura 36 - Curva dose-resposta da amostra CPS O 34 (intensidade de bioluminescência versus fator de concentração) - $2^{\mathrm{a}}$ replicata da amostra de Campinas com maiores tempo de contato concentração de ozônio. 



\section{LISTA DE TABELAS}

Tabela 1 - Condições experimentais nos ensaios de cloração de água da ETA de São Carlos57

Tabela 2 - Condições experimentais nos ensaios de cloração de água da ETAs 3 e 4 de

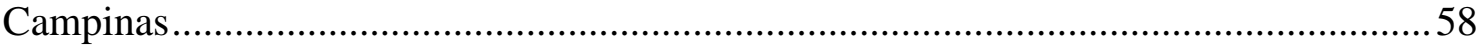

Tabela 3 - Condições experimentais nos ensaios de ozonização de água da ETA de São Carlos 60

Tabela 4 - Condições experimentais nos ensaios de ozonização de água da ETAs 3 e 4 de Campinas

Tabela 5 - Atividade estrogênica residual das amostras de água filtrada da ETA de São Carlos, contaminadas com 6.000 ngE2equiv $\mathrm{L}^{-1}$ e submetidas à cloração 68

Tabela 6 - Remoção da Atividade estrogênica das amostras de água filtrada da ETA de São Carlos, contaminadas com 6.000 ngE2equiv $\mathrm{L}^{-1}$ e submetidas à cloração

Tabela 7 - Atividade estrogênica residual das amostras de água filtrada das ETAs 3 e 4 de Campinas, contaminadas com 6.000 ngE2equiv $\mathrm{L}^{-1}$ e submetidas à cloração................ 74

Tabela 8 - Remoção da Atividade estrogênica das amostras de água filtrada da ETAs 3 e 4 de

Campinas, contaminadas com 6.000 ngE2equiv $\mathrm{L}^{-1} \mathrm{e}$ submetidas à cloração. 75

Tabela 9 - Atividade estrogênica residual das amostras de água filtrada das ETA de São Carlos, contaminadas com 6.000 ngE2equiv $\mathrm{L}^{-1}$ e submetidas à ozonização.

Tabela 10 - Remoção da Atividade estrogênica das amostras de água filtrada das ETA de São Carlos, contaminadas com 6.000 ngE2equiv $\mathrm{L}^{-1}$ e submetidas à ozonização.

Tabela 11 - Atividade estrogênica residual das amostras de água filtrada das ETAs 3 e 4 de Campinas, contaminadas com 6.000 ngE2equiv $\mathrm{L}^{-1}$ e submetidas à ozonização

Tabela 12 - Remoção da Atividade estrogênica das amostras de água filtrada das ETAs 3 e 4 de Campinas, contaminadas com 6.000 ngE2equiv $\mathrm{L}^{-1}$ e submetidas à ozonização. 



\section{SUMÁRIO}

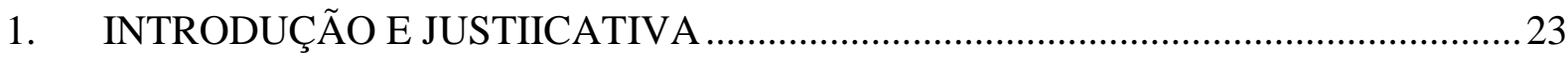

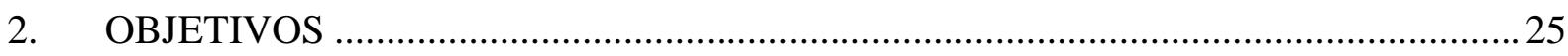

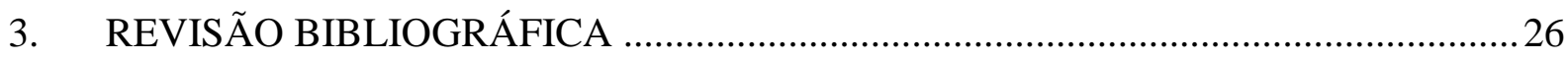

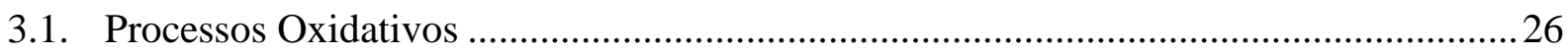

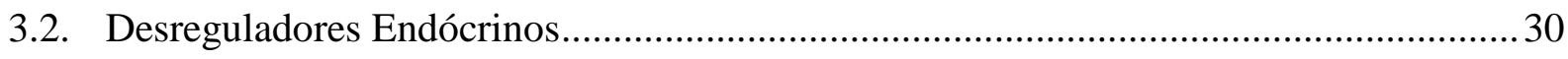

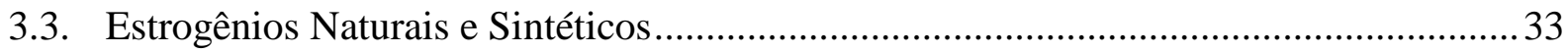

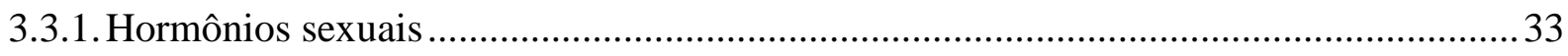

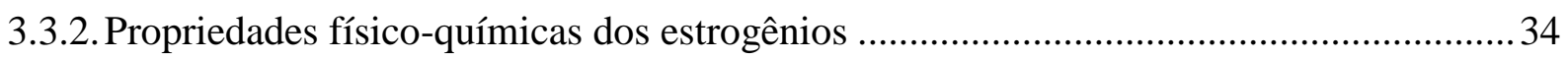

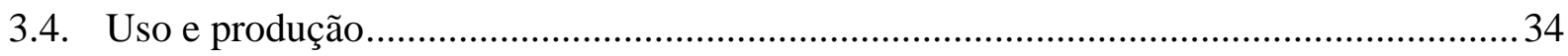

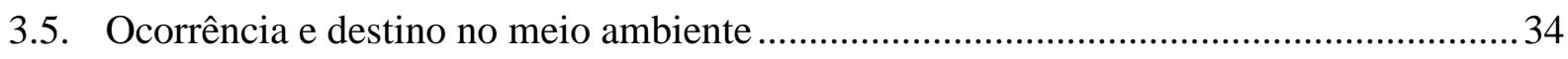

3.6. Bioensaios para determinação de atividade estrogênica ....................................................36

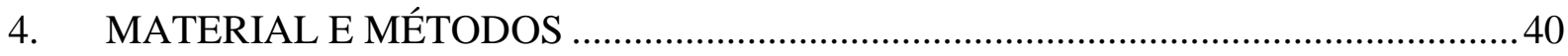

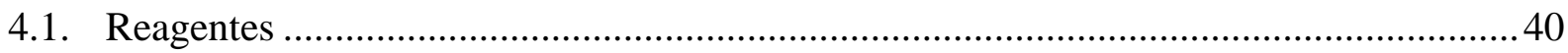

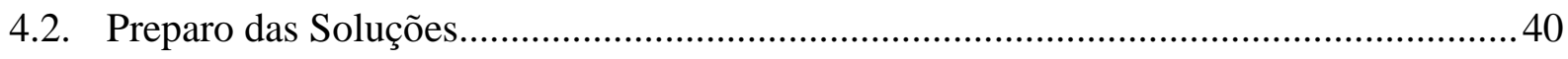

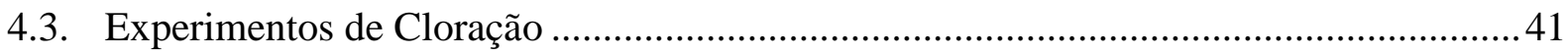

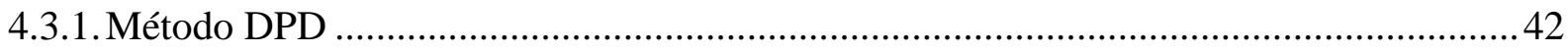

4.4. Experimentos de Ozonização ...................................................................................... 42

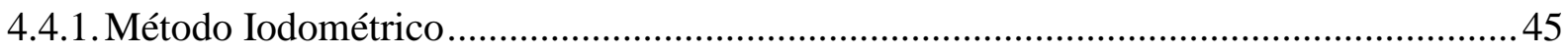

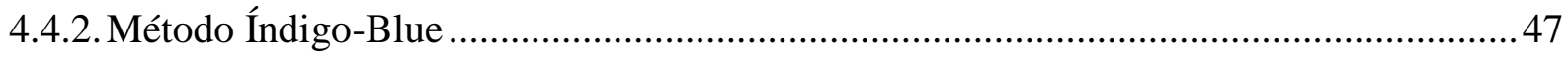

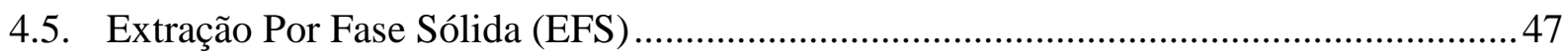

4.6. Teste BLYES (Bioluminescent Yeast Estrogen Screen) …………………………….... 49

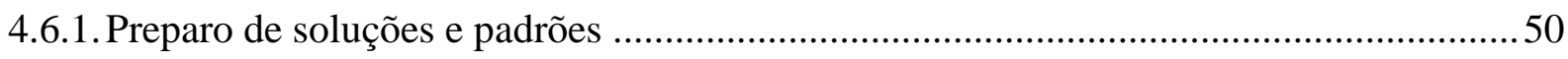

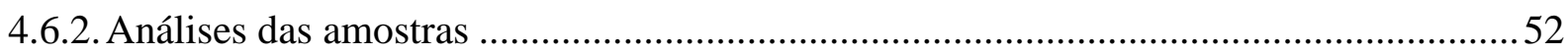

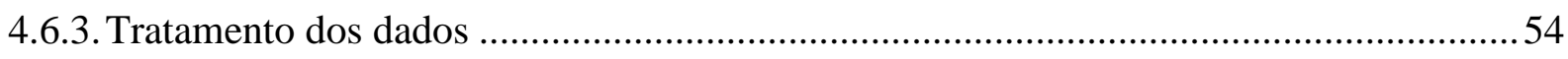

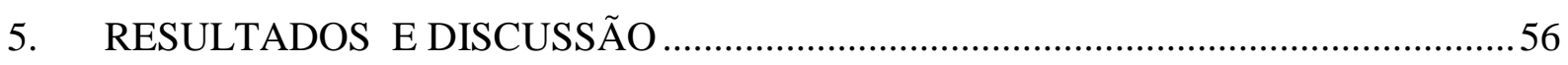

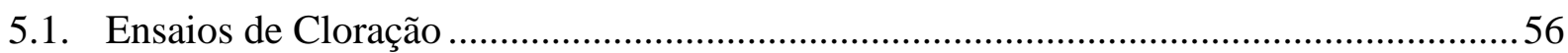

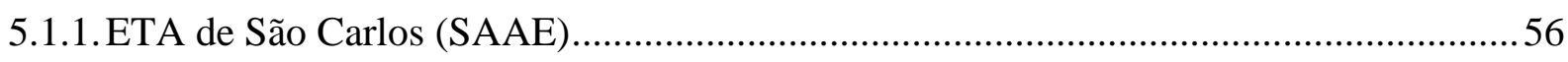

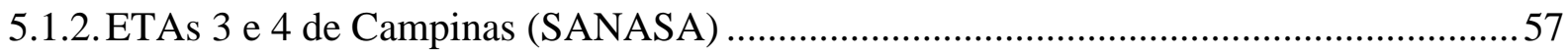

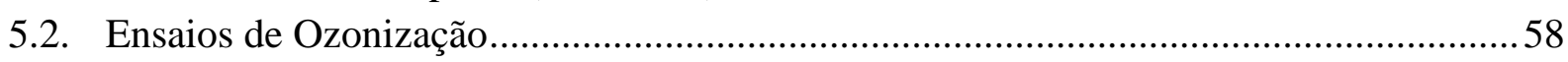

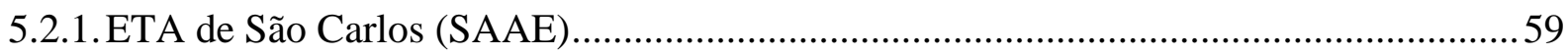

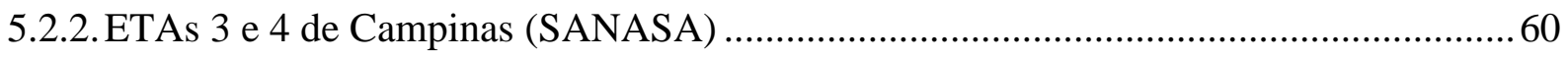

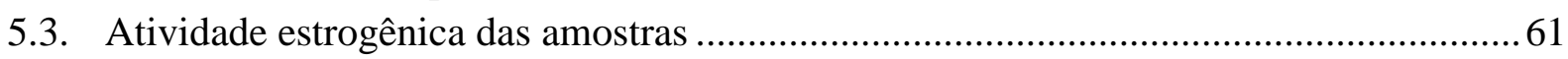

5.4. Amostras contaminadas com $17 \beta$-estradiol e tratadas com cloro …………………….......62

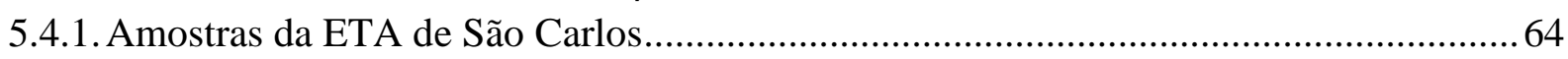

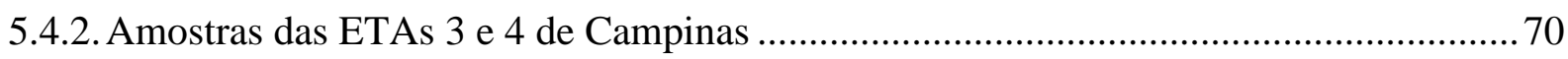

5.5. Amostras contaminadas com 17ß-estradiol e tratadas com ozônio ……………………...76

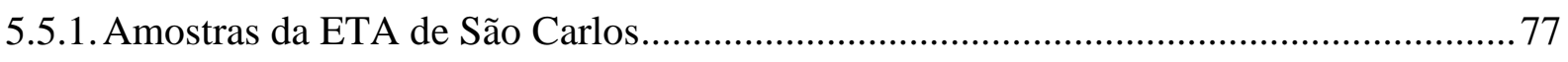

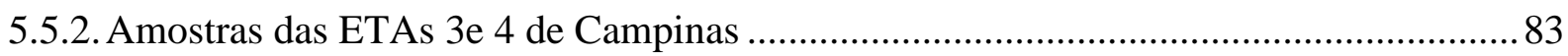


5.6. Comparação dos resultados de remoção da atividade estrogênica com a utilização de cloro e ozônio 88

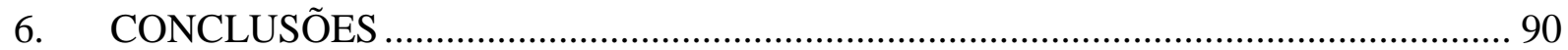

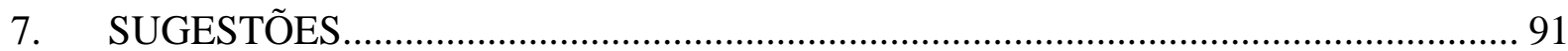

8. REFERÊNCIAS BIBLIOGRÁFICAS …………………...................................... 92 


\section{INTRODUÇÃO E JUSTIICATIVA}

Os processos oxidativos têm sido cada vez mais utilizados no tratamento de determinados tipos de despejos industriais contendo substâncias orgânicas recalcitrantes à ação de micro-organismos que atuam na degradação biológica.

Muitos oxidantes químicos reativos acarretam na ruptura de estruturas moleculares complexas de vários tipos de compostos orgânicos decompondo-as em estruturas mais simples e propiciando condições melhores para uma efetiva ação de micro-organismos na degradação biológica.

Embora a posição relativa de um oxidante na escala de potencial de redução seja indicativa de sua capacidade de oxidar outras matérias, ela não é indicativa da velocidade de reação, nem quão completa será esta reação no que tange à formação de $\mathrm{CO}_{2}$ e $\mathrm{H}_{2} \mathrm{O}$ (CAVALCANTI, 2009).

Estudos mostram que os desreguladores endócrinos são suspeitos de provocar desenvolvimento de algumas doenças como câncer de mama, de útero e de próstata, desenvolvimento sexual anormal, redução de fertilidade masculina, aumento de incidência de ovários policísticos, alteração de glândulas tireóides, distúrbios nas funções do ovário (crescimento folicular e a ovulação), na fertilização e gravidez. Em animais podem desregular a reprodução e o desenvolvimento dos organismos, assim como, induzirem, irreversivelmente, características sexuais femininas em peixes machos, podendo levar à esterilização ou redução da reprodução (COLEMAN et al., 2005; HARISSON et al., 1997, REIS FILHO, 2008).

O 17ß-estradiol é o principal estrogênio natural, responsável pela formação das características femininas e o $17 \alpha$-etinilestradiol é o principal estrogênio sintético, encontrado nas pílulas anticoncepcionais e aplicado nas terapias de reposição hormonal.

A presença desses hormônios em estações de tratamento de esgoto e em águas subterrâneas e superficiais mostra a necessidade de uma avaliação dos processos de tratamento em uso referente à eficiência de remoção dessas substâncias (FERREIRA 2008). 
Processos como a cloração, ozonização e os processos oxidativos avançados (POA), como a fotocatálise, fotólise, $\mathrm{O}_{3} / \mathrm{H}_{2} \mathrm{O}_{2}$ e $\mathrm{O}_{3} / \mathrm{UV}$, são tecnologias que têm se mostrado bastante promissoras na remoção desses micropoluentes presentes em amostras ambientais (BILA et al 2007).

A preocupação com a remoção de desreguladores endócrinos é recente, e ainda não há regulamentação específica para estes micropoluentes (encontrados em mananciais na ordem de pg ou ng $\mathrm{L}^{-1}$ ), bem como ainda não há completo entendimento dos mecanismos envolvidos na oxidação destas substâncias utilizando-se diferentes agentes oxidativos. Técnicas mais sensíveis, rápidas e que não requerem significativa infraestrutura laboratorial, como bioensaios in vitro, vêm impulsionando pesquisas na área de monitoramento de mananciais, efluentes e águas para abastecimento humano.

É importante verificar a existência desses micropoluentes em mananciais e avaliar a sua remoção após a interação entre esses poluentes com diferentes agentes oxidantes comercialmente viáveis, como o cloro e o ozônio, empregando técnicas modernas para a identificação e quantificação da atividade estrogênica. 


\section{OBJETIVOS}

O objetivo deste trabalho foi avaliar a remoção de estrogenicidade do hormônio $17 \beta$ estradiol quando adicionado à água efluente aos filtros de duas estações de tratamento de água em escala real.

Para tanto, foram objetivos específicos:

a) Avaliar e comparar os processos de oxidação do hormônio $17 \beta$-estradiol com cloro e com ozônio em duas matrizes.

b) Avaliar a aplicabilidade do teste BLYES para quantificar a estrogenicidade do residual de hormônio e dos subprodutos formados pela oxidação. 


\section{REVISÃO BIBLIOGRÁFICA}

\subsection{Processos Oxidativos}

Os processos oxidativos, como a cloração ou ozonização, empregados normalmente no tratamento de efluentes e de águas para abastecimento humano, vem demonstrando eficiência na remoção dos desreguladores endócrinos (SNYDER et al., 2003; MONTAGNER et al., 2011). O cloro, tradicionalmente utilizado na desinfecção de águas para abastecimento de esgotos, como é o caso do Brasil e Estados Unidos, etc., vem se mostrado uma técnica promissora e adequada para a oxidação de desreguladores endócrinos. Entretanto, a formação de subprodutos da oxidação desperta preocupação, visto que tem sido observado que mesmo amostras que tenham tido a remoção dos desreguladores endócrinos, permaneceram apresentando atividade estrogênica por conta da persistência de subprodutos da oxidação (SNYDER et al., 2003; WESTERHOFF et al., 2005; PEREIRA et al., 2011).

O cloro oxida a membrana celular e pode causar modificações nas moléculas levando a mutações genéticas. Em ETAs o cloro gás é o desinfetante mais utilizado no Brasil, sendo que este quando aplicado na água tende a diminuir seu $\mathrm{pH}$, enquanto que os hipocloritos tendem a aumentar (PEREIRA et al., 2011).

Quando o cloro gasoso ou hipoclorito de sódio são adicionado à água, ocorre à sua hidrólise e a solução passará a conter basicamente duas formas de cloro livre: o ácido hipocloroso $(\mathrm{HOCl})$ e o íon hipoclorito $\left(\mathrm{OCl}^{-}\right)$. O equilíbrio e as reações químicas são intimamente dependentes do $\mathrm{pH}$ e da temperatura sendo rápida e reversível. Em $\mathrm{pH}$ alto (maior que 8,5) predomina em solução o íon hipoclorito, que possui taxa de inativação de micro-organismos menor do que o ácido hipocloroso, o qual predomina em $\mathrm{pH}$ mais baixo (menor que 6,5). Se houver amônia na água a solução possivelmente conterá cloro combinado na forma de monocloramina, dicloramina e/ou tricloramina, sendo a proporções dessas também relacionadas ao pH da solução (USEPA, 1984). O cloro residual livre somado ao cloro residual combinado é denominado cloro residual total. 
A cloração de moléculas e matéria orgânica resulta na formação de subprodutos de oxidação, entre eles os trihalometanos, ácidos haloacéticos, halocetonas, entre outros.

É importante ressaltar que a preocupação com estas substâncias é recente, e ainda não há regulamentação específica para os desreguladores endócrinos, bem como ainda não há completo entendimento dos mecanismos envolvidos na oxidação destas substâncias Assim, mostra-se necessária a realização de pesquisas nesta área, que envolvam técnicas para identificar e quantificar a estrogenicidade de amostras antes e após processos oxidativos como a cloração (MONTAGNER et al., 2011).

Conforme relatado por Montagner (2011), a ozonização tem sido uma das técnicas mais empregadas em diversas ETA devido ao seu alto potencial de oxidação que tem se mostrado eficiente na desinfecção, remoção da cor, controle de sabor e odor, decréscimo na formação de sub-produtos de processos de oxidação, aumento da biodegradabilidade e também para a degradação de contaminantes orgânicos.

O ozônio reage com moléculas orgânicas tanto pela reação direta com o ozônio molecular $\left(\mathrm{O}_{3}\right)$ como pela reação indireta com os radicais livres (radical hidroxila $\mathrm{OH}$, por exemplo) formados pela decomposição do ozônio em meio aquoso. No entanto a taxa de formação e consumo do $\mathrm{OH} \bullet$ depende da matriz, especialmente do $\mathrm{pH}$ (alcalino), do tipo e da quantidade de matéria orgânica. $O$ ozônio molecular reage seletivamente com ligações insaturadas, anéis aromáticos e grupos amino, enquanto que as reações com os radicais hidroxilas são mais rápidas e não seletivas. A eficiência de remoção depende, portanto das constantes de reação do contaminante com o ozônio e com os radicais hidroxilas (MONTAGNER et al., 2011).

No entanto, determinadas aplicações requerem a combinação de várias tecnologias de oxidação, entre elas podem ser citadas a combinação da desinfecção por ozônio com a UV, como sendo:

- Efetiva: todos os micro-organismos são suscetíveis à desinfecção por ozônio;

- Conveniente: além de a desinfecção eliminar contaminantes orgânicos e metais oxidáveis, o ozônio reduz a dureza da água; 
- Ozônio não adiciona outros elementos químicos à água, exceto Oxigênio;

- Econômica: apresenta baixos custos inicial de capital ou operacionais;

- Simples: instalação e operação descomplicadas;

- Comparativo com sistema convencional de desinfecção em sistemas com exigência de cloro residual: para determinados sistemas (por exemplo, piscinas públicas) há a exigência legal de presença de cloro residual, requerendo a combinação do sistema de oxidação por UV ou Ozônio com a cloração.

Nestes casos o uso de ozônio é extremamente favorável, pois diminui o consumo de cloro em até $90 \%$, além de reduzir a formação de trihalometanos.

A combinação de ozônio com radiação UV e peróxido de hidrogênio $\left(\mathrm{H}_{2} \mathrm{O}_{2}\right)$, resulta em processos de tratamento que podem ser mais poderosos que apenas ozônio. Com isso, o ozônio pode se decompor por mecanismos que envolvem a geração de radicais $\mathrm{HO} \bullet$, os quais são espécies mais reativas. Os processos caracterizados pela geração de radicais $\mathrm{HO}$ • são conhecidos como Processos Oxidativos Avançados (POA), pois o radical HO• é um forte agente oxidante capaz de destruir compostos que não podem ser oxidados por oxidação convencional, ou seja, por cloro. (ANDREOZZI et al., 1999, GLAZE, 1987, GLAZE e KANG, 1989)

Os POAs são caracterizados também pela sua versatilidade, uma vez que a obtenção dos radicais $\mathrm{HO}$ • pode ser por vários meios e combinações entre os oxidantes, de modo a se obter uma associação apropriada para um problema específico.

Os POAs geralmente usam uma combinação de agentes oxidantes $\left(\mathrm{H}_{2} \mathrm{O}_{2}\right.$ ou $\left.\mathrm{O}_{3}\right)$, irradiação (UV ou ultra-som) e catalisadores (íons metálicos ou foto catalisadores) com o objetivo de gerar radicais $\mathrm{HO} \bullet$.

Esses radicais são espécies muito reativas e com baixa seletividade, que reagem com a maior parte das moléculas orgânicas com constantes de reação na ordem de $10^{6}$ a $10^{9} \mathrm{M}^{-1} \mathrm{~s}^{-1}$ (GLAZE,1987, ANDREOZZI et al., 1999).

Silveira (2004) usou em sua pesquisa a combinação dos oxidantes hipoclorito de sódio e ozônio para remoção de matéria orgânica de efluente hospitalar e a posterior inativação de 
coliformes totais. A toxicidade gerada nos processos de desinfecção foi avaliada em Daphnia similis. Os efluentes hospitalares apresentam semelhanças aos efluentes domésticos no que diz respeito à concentração de matéria orgânica, coliformes e pH e ambos são, geralmente, coletados pela rede de esgotos e enviados para mesma estação de tratamento. Contudo, substâncias como fármacos, desinfetantes e compostos químicos, bem como organismos patogênicos multirresistentes a antimicrobianos podem ocorrer em elevadas concentrações nas águas residuárias hospitalares.

O sistema de tratamento biológico piloto utilizado (em SILVEIRA, 2004), constituído por uma série de quatro contatores biológicos rotatórios em PVC, com volume útil de $40 \mathrm{~L}$ cada, operando de modo contínuo (configurando um tempo de detenção hidráulico de $2 \mathrm{~h}$ em cada uma das quatro unidades) mostrou-se adequado, obtendo-se remoção de matéria orgânica na ordem de $80 \%$ em termos de DQO, e no término do experimento atingiu-se 88,5\% da remoção de DQO para o tempo de detenção hidráulico de 2,28 horas. A toxicidade aguda do efluente, verificada em Daphnia similis, aumentou após adição de cloro, mas foi reduzida quando houve descloração com tiossulfato de sódio. Com adição de ozônio, verificou-se variabilidade nos resultados, mas geralmente houve aumento da toxicidade após aplicação de elevadas dosagens as quais foram necessárias para desinfecção.

Ferreira (2008) utilizou em sua pesquisa os processos de ozonização e $\mathrm{O}_{3} / \mathrm{H}_{2} \mathrm{O}_{2}$ para remoção de estrogênios $17 \beta$-estradiol e $17 \alpha$-etinilestradiol detectados em efluentes de estações de tratamento de esgoto e em águas superficiais e subterrâneas, onde foram investigadas as influências do $\mathrm{pH}$ e da dosagem de ozônio na remoção dos estrogênios, da atividade estrogênica e na formação dos intermediários. Os resultados mostraram que os processos de ozonização e $\mathrm{O}_{3} / \mathrm{H}_{2} \mathrm{O}_{2}$ foram efetivos na remoção desses estrogênios. Em pH 3, a atividade estrogênica foi totalmente removida, mesmo com baixas dosagens de ozônio (1 $\mathrm{mg} \mathrm{L}^{-1}$ ), tanto para o processo de ozonização quanto para $\mathrm{O}_{3} / \mathrm{H}_{2} \mathrm{O}_{2}$. Entretanto, em $\mathrm{pH} 7$ e 11 a estrogenicidade não foi completamente removida, provavelmente devido aos subprodutos formados pela oxidação via radical $\mathrm{HO} \bullet$.

Pereira (2011) avaliou a oxidação de diferentes concentrações de $17 \beta$-estradiol em contato com cloro. No estudo, a influência da concentração inicial de 17ß-estradiol foi observada, sendo que quanto maior a concentração inicial, maior foi a remoção. Para a mesma combinação de concentração de cloro $\left(0,5 \mathrm{mg} \mathrm{L}^{-1}\right)$ e tempo de contato (30 min), obtiveram-se 
as eficiências de remoção de 73, 47 e 39\% para as concentrações inicias de, respectivamente, 17ß-estradiol de $100 \mu \mathrm{g} \mathrm{L}^{-1}, 1 \mu \mathrm{g} \mathrm{L} \mathrm{L}^{-1}$ e $100 \mathrm{ng} \mathrm{L} \mathrm{L}^{-1}$. Foi verificado que o coeficiente CT (produto da concentração de cloro e tempo de contato), usualmente utilizado para avaliação do cloro em processos de oxidação, não se mostrou adequado para avaliar o comportamento da cloração de $17 \beta$-estradiol, pois nem sempre foi verificada uma correlação entre o aumento do CT com aumento da remoção de $17 \beta$-estradiol.

Utilizando o ozônio como desinfetante, Pereira (2011) verificou que para a remoção de $17 \beta$-estradiol e estrona, foram necessárias dosagens elevadas desse agente oxidante para que estes compostos não fossem mais detectados em UPLC-QqQ-MS/MS. A completa eliminação (<LD) do estrona ocorreu com uma dose de ozônio de $10 \mathrm{mg} \mathrm{L}^{-1}$, sendo que com a dosagem anteriormente aplicada de ozônio, $3,8 \mathrm{mg} \mathrm{L}^{-1}$, a concentração de E1 quantificada foi de 1,4 ng $\mathrm{L}^{-1}$. Para a completa eliminação $(<\mathrm{LD})$ do $17 \beta$-estradiol a dose necessária de ozônio foi de 4,2 $\mathrm{mg} \mathrm{L}^{-1}$, sendo que com a dosagem anteriormente aplicada de ozônio de $0,95 \mathrm{mg} \mathrm{L}^{-1}$ a concentração de E2 quantificada foi de 7,0 $\mathrm{ng} \mathrm{L}^{-1}$. Os limites de detecção encontrados para ambos hormônios é de $0,01 \mathrm{ng} \mathrm{L}^{-1}$.

Ao se comparar a eficiência de remoção entre o $17 \beta$-estradiol e o estrona, verificou-se que nas condições estudadas o $17 \beta$-estradiol apresentou uma maior remoção do que o estrona quando o cloro foi utilizado como oxidante. No entanto, quando o ozônio foi considerado como oxidante, obteve-se uma maior remoção do estrona do que do 17 $\beta$-estradiol (PEREIRA, 2011).

\subsection{Desreguladores Endócrinos}

As substâncias denominadas desreguladores endócrinos (DEs) são uma recente categoria de contaminantes ambientais que interferem nas funções do sistema endócrino. Essas substâncias são encontradas no meio ambiente em concentrações da ordem de $\mu \mathrm{g} \mathrm{L}^{-1} \mathrm{e}$ ng $\mathrm{L}^{-1}$, e são suspeitas de causarem efeitos negativos à saúde humana e animal.

Os interferentes endócrinos, por apresentarem atividade de desregulação das glândulas endócrinas, produtoras de hormônios, têm preocupado cientistas e autoridades sanitárias em 
função de sua rápida disseminação pelas reservas de água do planeta. Estudos revelam que, dependendo do nível de concentração em que se encontram na água, eles podem provocar a feminilização de peixes e anfíbios, gerar anomalias sexuais em moluscos e reduzir a taxa de fertilidade de ursos polares, no caso do hemisfério Norte (VASCONCELOS,2012).

Suspeita-se, também, de que a presença desses poluentes na água para consumo humano esteja antecipando a primeira menstruação de meninas e reduzindo o número de espermatozoides em homens. Esses compostos são um vasto grupo de hormônios, entre eles os hormônios sexuais naturais femininos estrona (E1), 17ß-estradiol (E2) e estriol (E3), o

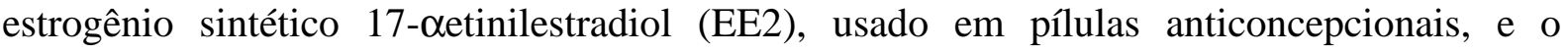
bisfenol A, composto industrial que participa da produção de vários produtos, como plásticos policarbonatos, resinas epóxi, fungicidas e alguns tipos especiais de papel. (VASCONCELOS, 2012)

Os DEs podem interferir com o funcionamento do sistema endócrino pelo menos de três formas: (1) mimetizam a ação de um hormônio endógeno, como o estrogênio ou a testosterona, afetando as funções que esses hormônios controlam; (2) bloqueiam os receptores hormonais nas células, impedindo assim a ação dos hormônios naturais; (3) afetam a síntese, o transporte, o metabolismo e a excreção dos hormônios, alterando dessa forma as concentrações dos hormônios naturais no corpo (COMISSÃO EUROPÉIA, 1996). Alterações nas funções do sistema endócrino podem prejudicar a saúde do organismo, da sua descendência ou de uma (sub) população (BILA, 2005; GUIMARÃES e DUARTE, 2007; STAVRAKAKIS et al., 2008).

Efeitos tais como diminuição na eclosão de ovos de pássaros, peixes e tartarugas; feminização de peixes machos; deformidade em peixes; problemas no sistema reprodutivo em répteis, pássaros e mamíferos; e alteração no sistema imunológico de mamíferos marinhos têm sido associados à exposição de espécies de animais aos desreguladores endócrinos. Em alguns casos esses efeitos podem conduzir ao declínio da população. Em seres humanos esses efeitos incluem a redução da quantidade de esperma, o aumento da incidência de câncer de mama, de testículo e próstata, e a endometriose (BILA, 2005; REIS FILHO, 2008).

Em particular, efluentes oriundos de ETEs aparentam ser a maior fonte de liberação de compostos estrogênicos em rios, córregos e águas superficiais, mostrando que a eficiência do 
tratamento, tanto em países desenvolvidos como em desenvolvimento, é apenas parcial (ZORITA et al. 2009).

As substâncias classificadas como DEs, incluindo substâncias naturais e sintéticas, usadas ou produzidas para uma infinidade de finalidades, podem ser agrupadas em quatro classes:

a) Substâncias sintéticas utilizadas na agricultura e seus subprodutos, como pesticidas, herbicidas, fungicidas e moluscicidas;

b) Substâncias sintéticas utilizadas nas indústrias e seus subprodutos, dioxinas, PCBs, alquilfenóis e seus subprodutos, HAP, ftalatos, bisfenol A, entre outros;

c) Substâncias naturais, como fitoestrogênios, tais como, genisteína e metaresinol e os estrogênios naturais $17 \beta$-estradiol, estrona e estriol;

d) Compostos farmacêuticos, como o DES e o 17 $\alpha$-etinilestradiol.

O 17ß-estradiol é um hormônio esteróide natural liberado por seres humanos e animais e um potencial desregulador endócrino, variando a níveis de $n g \mathrm{~L}^{-1}$ (GENTILI et al., 2002; STAVRAKAKIS et al., 2008; BLANQUEZ e GUIEYSSE, 2008). Estrógenos são excretados principalmente como conjugados inativos de ácido sulfônicos e glucurônicos, os quais são clivados em esteróides estrogênicos ativos durante os processos tratamento de esgoto, sendo lançados no ambiente (PURDON et al., 1994).

Pesquisas demonstram a presença da estrona, 17 $\beta$-estradiol, como fonte de atividade estrogênica em muitos efluentes (SOLÉ et al., 2003). Estrogênios naturais são encontrados em efluentes de ETE e águas superficiais em várias partes do mundo (TERNES et al., 1999a, BELFROID et al., 1999, LOPÉZ e BARCELO, 2001).

Alguns agentes terapêuticos e farmacêuticos também estão na lista das substâncias classificadas como desreguladores endócrinos. São hormônios sintéticos usados como contraceptivos orais, na reposição terapêutica na menopausa ou na prevenção do aborto, tais como, o DES e o $17 \alpha$-etinilestradiol. A maior aplicação médica do $17 \alpha$-etinilestradiol tem sido no desenvolvimento de pílulas contraceptivas, as quais contém de 30 a $50 \mu \mathrm{g}$ de 17a-etinilestradiol (BEAUSSE, 2004). O DES foi muito usado nos anos 1970 na prevenção do aborto (BIRKETT e LESTER, 2003). 


\subsection{Estrogênios Naturais e Sintéticos}

\subsubsection{Hormônios sexuais}

Os hormônios esteróides são produzidos nas glândulas endócrinas e são excretados diretamente na corrente sanguínea, estimulando ou inibindo a atividade metabólica em outros tecidos ou órgãos. Os hormônios sexuais, que controlam a maturação e a reprodução, podem ser classificados em três grupos principais: (1) os hormônios sexuais femininos, tais como, estrogênios e progesteronas, (2) os hormônios sexuais masculinos, tais como, androgênios e (3) corticosteróides, que são divididos em glicocorticóides e mineralocorticóides (BILA, 2005).

Todos os hormônios esteróides exercem sua ação pela passagem através da membrana plasmática e acoplam-se a receptores intracelulares (YING et al., 2002). Os hormônios esteroides, como o 17ß-estradiol são um grupo de substâncias ativas biologicamente que são sintetizadas a partir do colesterol, e têm em comum uma estrutura de anel básica, constituída de três anéis hexagonais (A, B, C) e um anel pentagonal (D), como apresentado na Figura 1. Os estrogênios são caracterizados por seu anel A fenólico, o qual tem o grupamento hidroxila no carbono 3 e é o que lhe confere à atividade biológica, neste caso a atividade estrogênica, e uma cetona ou um grupamento hidroxila no carbono 17. São também referidos como esteróides C18, por apresentar 18 carbonos em sua estrutura.

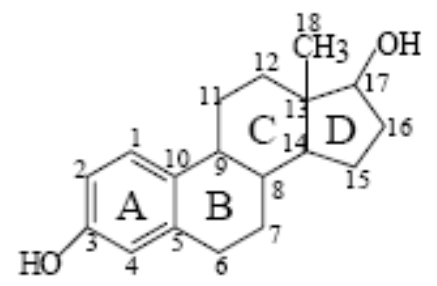

Figura 1 - Fórmula estrutural do 17ß-estradiol (BILA, 2005) 


\subsubsection{Propriedades físico-químicas dos estrogênios}

Os estrogênios naturais estrona, 17ß-estradiol e estriol têm solubilidade em água de aproximadamente $13 \mathrm{mg} \mathrm{L}^{-1}$, o estrogênio sintético $17 \alpha$-etinilestradiol tem solubilidade mais baixa, 4,8 $\mathrm{mg} \mathrm{L}^{-1}$ (YING et al., 2002). Todos esses estrogênios têm pressão de vapor na faixa de $2,3 \times 10^{-10}$ a $6,7 \times 10^{-15} \mathrm{~mm} \mathrm{Hg}$ indicando baixa volatilidade. São compostos orgânicos hidrofóbicos, em baixa volatilidade, moderadamente solúveis em água e adsorvem em sedimentos/partículas sólidas. É de se esperar que a adsorção no solo, ou sedimento ou lodo biológico seja um significativo fator na redução de concentrações na fase aquosa (LAI et al., 2000). Durante o tratamento biológico, provavelmente, parte desses estrogênios fica retida no lodo biológico (na camada lipolítica das células), devido à sua hidrofobicidade, e consequentemente pode ocorrer bioacumulação (BILA, 2005).

\subsection{Uso e produção}

Os estrogênios naturais são usados na medicina humana (na terapia de substituição hormonal), no tratamento de distúrbios ginecológicos e nos tratamentos de câncer de próstata e de mama. Na medicina veterinária são usados como promotor de crescimento animal (BILA, 2005).

\subsection{Ocorrência e destino no meio ambiente}

Os estrogênios naturais (estrona, 17ß-estradiol e estriol) são excretados na urina por mulheres, fêmeas de animais e, em menor quantidade, por homens na forma de conjugados polares inativos, predominantemente na forma de glucuronídeos e sulfatos. No entanto, estudos demonstram que esses estrogênios são encontrados nas ETE também na forma livre, 
sugerindo que ocorrem reações de transformação dessas substâncias durante o processo na ETE (JOHNSON e SUMPTER, 2001, TERNES et al., 1999a).

Devido ao efeito potencial dos estrogênios em espécies de animais e humanos, fica claro que a ocorrência dessas substâncias no esgoto doméstico e águas naturais são muito importantes. Estudos demonstram que esses micropoluentes e seus metabólitos estão presentes em ambientes aquáticos, em faixas de concentrações de $\mu \mathrm{g} \mathrm{L}^{-1}$ e ng L $\mathrm{L}^{-1}$, em várias partes do mundo, tais como, Alemanha, Áustria, Brasil, Canadá, Espanha, Holanda, Inglaterra, Itália, Japão, Suíça, Estados Unidos, Reino Unido e França (BILA, 2005).

Uma vez no meio aquático, os estrogênios estão sujeitos a vários processos, tais como diluição, fotólise, biodegradação e sorção em sedimentos, em partículas orgânicas e no lodo biológico, os quais podem contribuir para sua remoção da fase aquosa. O processo de adsorção no lodo biológico é de grande importância, pois é o primeiro estágio de biodegradação que contribui para sua remoção do meio ambiente (CLARA et al., 2004).

Os processos de tratamentos convencionais em uma ETE consistem em: tratamento preliminar (gradeamento e caixa de areia), tratamento primário (sedimentação primária) e tratamento secundário (tratamento biológico). No tratamento preliminar os sólidos grosseiros são retirados e muito pouca remoção de micropoluentes é observada. No tratamento primário, há a adsorção dessas substâncias sobre os sólidos do lodo primário. Substâncias hidrofóbicas, como muitos desreguladores endócrinos, são removidas da fase líquida junto com o lodo primário. O grau de remoção de compostos orgânicos é bastante e dependente da remoção de sólidos suspensos pelo processo de sedimentação. A remoção de poluentes orgânicos durante o tratamento biológico inclui a adsorção nos flocos microbianos e posterior remoção no lodo biológico, degradação química e biológica, e transformação e volatilização durante a aeração (BILA, 2005). 


\subsection{Bioensaios para determinação de atividade estrogênica}

Segundo Raimundo (2011), dentre os bioensaios, um ensaio baseado nas interações antígeno-anticorpo, denominado YES (Yeast Estrogen Screen) desenvolvido por Routledge e Sumpter (1996) vem sendo largamente utilizado para a avaliação da atividade estrogênica de amostras ambientais tais como efluentes de ETE, águas superficiais, águas estuarinas, água tratada bem como para avaliar a eficiência de diferentes tipos de tratamento de efluentes.

No YES a atividade estrogênica de compostos químicos é medida utilizando uma linhagem de levedura (Saccharomyces cerevisae) que contém um gene de estrógeno humano (hER), capaz de responder a agentes estrogênicos, medida através da atividade da $\beta$ galactosidade. O gene repórter do sistema quando entra em contato com compostos estrogênicos desencadeiam uma serie de reações resultando na variação da intensidade da resposta colorimétrica. Diferentes linhagens de leveduras foram desenvolvidas por diversos pesquisadores (JARDIM et al., 2012).

A análise dos resultados de bioensaios in vitro como os testes YES e BLYES (Bioluminescent Yeast Estrogen Screen) são baseadas na comparação entre as amostras e a curva padrão elaborada rotineiramente. A expressão da levedura tem correlação com as diluições, ou concentrações, realizadas e tem-se por objetivo comparar resposta real obtida através dos ensaios de diluição com o padrão de referência, ou seja, o 17ß-estradiol (E2). Esta comparação resulta na potência relativa das amostras, expressas em E2 equivalente. Para os testes YES e BLYES, bem como na maioria dos bioensaios in vitro, a determinação da potência relativa é feita com base nos valores de $\mathrm{EC}_{50}$, que é o valor que elucida $50 \%$ da resposta da curva padrão de 17ß-estradiol (JARDIM et al., 2012; BILA, 2005).

É importante ressaltar que os testes são muito sensíveis, chegando a limites de quantificação de até $2 \mathrm{ngL}^{-1}$ de equivalente E2 para o YES (ROUTLEDGE e SUMPTER, 1996) e em 0,1 $\mathrm{ngL}^{-1}$ de equivalente E2 para o BLYES. Considerando a alta sensibilidade dos ensaios, a pureza dos reagentes e a limpeza dos equipamentos, vidrarias e materiais utilizados nas diversas etapas envolvidas na calibração, preparo de amostras e ensaios devem ser sempre alta, já que uma quantidade mínima de qualquer substância que interfira no teste poderá resultar na expressão errada dos bioensaios. 
Mesmo os recipientes de vidro utilizados para armazenar os meios devem ser cuidadosamente limpos, já que qualquer contaminação por compostos que expressam positivamente ou com inibição em relação levedura nos vidros podem afetar a resposta dos bioensaios, causando resultados falso positivos ou inibição do crescimento da cepa (FISHER 2013; JARDIM et al., 2012).

Os testes YES e BLYES tem sido utilizado com sucesso na identificação de atividade estrogênica de compostos específicos de amostras ambientais e no controle de processos de tratamento de água para abastecimento humano e de efluentes industriais e sanitários. Em geral, a matriz analisada é submetida a um processo anterior de concentração, geralmente utilizando a extração em fase sólida (SPE), que tem sido empregada com sucesso na detecção de hormônios e fármacos desreguladores endócrinos (JARDIM et al., 2012; BILA, 2005; SNYDER et al., 2003).

Leskinen et al. (2003) desenvolveram uma nova linhagem de Saccharomyces que responde ao agente estrogênico emitindo luz (bioluminescência). As células dessa levedura naturalmente não possuem receptores para estrogênios ou androgênios. As linhagens utilizadas no ensaio foram então desenvolvidas a partir da inserção do gene para expressão do receptor de estrogênio humano. Neste sistema, o hER produzido liga-se aos elementos de resposta do estrogênio, que foram inseridos em forte promotor em um plasmídio. Este promotor controla a expressão do gene de vagalume ffluc, que codifica a produção da enzima luciferase. A levedura é capaz de emitir luz quando entra em contato com alguma substância que se liga ao hER, ativando o promotor e estimulando a síntese de luciferase (que metaboliza o substrato luciferina, produzindo luz).

Sanseverino et al. (2005) desenvolveram outra linhagem luminescente de Saccharomyces cerevisae chamada Bioluminescent Yeast Estrogen Screen (BLYES). Essa linhagem foi construída a partir da mesma linhagem de Routledge e Sumpter (1996), apenas com outro sistema repórter. O sistema repórter foi construído em um plasmídio contendo todo o aparato do gene lux, obtido de bactéria luminescente. Esta diferença é importante, pois dispensa a adição do substrato luciferina, um reagente de alto custo. Este ensaio se mostrou muito sensível, uma vez que a emissão de luz poderia ser detectada com facilidade e quantificada em poucas horas fornecendo limites de quantificação em níveis de pg $\mathrm{L}^{-1}$. 
Bergamasco (2010) comparou os bioensaios usando as linhagens desenvolvidas por Leskinen (2003) e Sanseverino (2005) e verificou que o protocolo descrito por Sanseverino et al. (2009), com a utilização de levedura bioluminescente, se mostrou mais sensível e mais simples, uma vez que não haveria necessidade de adicionar reagentes para promover a expressão de cor. Esse protocolo foi aplicado em diversos estudos, inclusive no presente trabalho de mestrado, interessados na determinação da atividade estrogênica de substâncias químicas e amostras complexas. (JARDIM et al., 2011; SANSEVERINO et al., 2009; SANSEVERINO et al., 2005).

Pereira (2011) avaliou os efeitos de biotoxicidade das amostras cloradas em um teste in vivo com peixes Danio rerio. Observou-se que, mesmo após a cloração das amostras contaminadas com esse hormônio, ainda foi observada atividade estrogênica nas mesmas, o que pode demonstrar que os subprodutos da cloração apresentam atividade estrogênica.

Hu et al (2003) estudaram a formação de subprodutos da cloração de $17 \beta$-estradiol e sua atividade estrogênica. Os ensaios foram realizados com concentração inicial de $50 \mu \mathrm{g} \mathrm{\textrm {L } ^ { - 1 }}$ de $17 \beta$-estradiol, pH 7,5 e temperatura $25^{\circ} \mathrm{C}$. Foi estudada a concentração de $1,46 \mathrm{mg} \mathrm{L}^{-1}$ de hipoclorito de sódio, nos tempos de contato de 10, 30, 60, 120 e $180 \mathrm{~min}$. Os subprodutos identificados apresentaram atividade estrogênica, em diferentes intensidades, e a eles foi atribuída a atividade estrogênica observada na água clorada. A máxima atividade estrogênica foi observada nas soluções cloradas a 10, 30 e 60 min, que foi pouco menor à observada antes da cloração. Para os tempos de contato de 120 e 180 min, a atividade estrogênica foi $40 \%$ menor do que a inicial. No caso dos tempos de contato inferiores a $60 \mathrm{~min}$, a presença de monocloro-E1 foi a origem principal da atividade estrogênica. Nos tempos de 120 e 180 min, a atividade foi atribuída à presença de 2,4-dicloro-E2 e 2,4-dicloro-E1.

Fisher (2013) estudou a oxidação do 17ß-estradiol com cloro em água de abastecimento, com foco na avaliação da remoção da estrogenicidade utilizando o teste YES. A escolha pela cloração foi feita visto que este é o tratamento mais difundido no Brasil, assim as concentrações e tempos de contato estudados também foram definidos de forma a corresponder àqueles utilizados regularmente em Estações de Tratamento de Água, porém nos ensaios apresentados, foram observados alguns problemas nas curvas dose-resposta do teste YES. O principal problema encontrado, e que ocorreu em todos os ensaios, foi a resposta fora do esperado para as amostras com 17ß-estradiol mais concentradas. Como um bioensaio in vitro, o teste YES deve atender a alguns requisitos para que as curvas dose-resposta das 
amostras possam ser comparadas com confiabilidade com a curva padrão. Entretanto, algumas destas condições não foram completamente atendidas no desenvolvimento de seu trabalho, como é o caso do paralelismo que deve existir entre as curvas dose-resposta e a curva padrão. Ainda, algumas de suas amostras causaram um efeito negativo, associado à toxicidade, no desenvolvimento da levedura durante o teste, o que prejudicou as curvas dose-resposta.

Raimundo (2011) avaliou em sua tese, através de um perfil anual, a qualidade dos mananciais e da água tratada de Campinas (SP) em relação à presença de cafeína, estrona, 17 $\beta$-estradiol, estriol, progesterona, testosterona, 17 $\alpha$-etinilestradiol, mestranol, levonorgestrel, dietilestilbestrol, triclosan, 4-n-octilfenol, 4-n-nonilfenol, bisfenol A, fenolftaleína e atrazina empregando extração em fase sólida (SPE) e cromatografia líquida acoplada ao espectrômetro de massas (LC-MS/MS), e verificado o potencial estrogênico das amostras usando o bioensaio Bioluminesce Yeast Estrogen Screening (BLYES).

Os resultados de atividade estrogênica endossaram a baixa eficiência das ETA na remoção de compostos interferentes endócrinos, principalmente no período de estiagem, uma vez que $40 \%$ das amostras de água tratada apresentaram estrogenicidade positiva para o bioensaio empregado. Todas as amostras de água bruta apresentaram estrogenicidade que variou entre 0,06 e 6,54 ngE2equiv $\mathrm{L}^{-1}$. O BLYES apresentou-se como uma ferramenta simples, que pode ser empregada na avaliação rotineira da qualidade da água distribuída à população no diagnóstico de potencial interferência endócrina.

Não houve correlação entre a resposta obtida por BLYES e a resposta esperada calculada com base nos contaminantes detectados e suas respectivas estrogenicidades, o que permite pressupor que outros compostos não abordados nesse trabalho estariam potencializando esses efeitos, mesmo que efeitos antagônicos tenham sido observados nas amostras de água bruta. 


\section{MATERIAL E MÉTODOS}

Os ensaios de cloração e ozonização das amostras de água filtrada, obtidas das ETAs de Campinas (SANASA) - com captação de água no rio Atibaia - e São Carlos (SAAE) com captação de água no Ribeirão Feijão e do Ribeirão Espraiado - contaminadas com 17ßestradiol, foram feitos no Laboratório de Tratamento Avançado e Reuso de Águas (LATAR) da Escola de Engenharia de São Carlos (EESC). As amostras contaminadas foram tratadas em condições extremas, ou seja, menores dosagem de oxidante e tempo de contato e maiores dosagem de oxidante e tempo de contato para ambos oxidantes, comumente utilizados nos tratamentos de água convencionais. As variáveis usadas para monitoramento foram: $\mathrm{pH}$, cor aparente, turbidez, cloro total, residual de ozônio em fase líquida e ozônio em fase gasosa, cujas metodologias estão descritas no Standard Methods for the Examination of Water and Wastewater (APHA, 2012). A estrogenicidade foi avaliada pelo teste BLYES.

\subsection{Reagentes}

Foram utilizados os seguintes reagentes: 17ß-Estradiol (pureza 99\%) de marca SigmaAldrich; Ácido Clorídrico, Ácido Sulfúrico, Metabissulfito de Sódio, Tiossulfato de Sódio e Iodeto de Potássio padrões analítico de marca Vetec; Hipoclorito de Sódio de marca Merck, Hexano grau HPLC de marca Panreac; Acetona grau HPLC de marca Mallinckrodt Chemicals; e Metanol e Acetonitrila graus HPLC de marca J.T. Baker.

\subsection{Preparo das Soluções}

A solução estoque de $17 \beta$-estradiol utilizada nos experimentos de cloração e de ozonização foi preparada a uma concentração de $100 \mathrm{mg} \cdot \mathrm{L}^{-1} \mathrm{em}$ metanol e estocada a $4{ }^{\circ} \mathrm{C}$. Nas ocasiões das contaminações das amostras de água filtrada obtidas das ETA de São Carlos e de Campinas, foram preparadas soluções intermediárias de $1.000 \mathrm{mg} . \mathrm{L}^{-1}$ a fim de 
incrementar as amostras com esse hormônio em $6.000 \mathrm{ng} \mathrm{L}^{-1}$. Tal concentração hormonal foi escolhida a fim de não se obter remoção total do hormônio nas amostras, podendo-se comparar a eficiência e eficácia dos diferentes métodos, tempo de contato e concentração dos ensaios de oxidação.

Foram preparadas soluções de metabissulfito de sódio $3 \%(\mathrm{~m} / \mathrm{v})$ para remover os agentes oxidantes após o tempo de contato desejado e de iodeto de potássio $2 \%(\mathrm{~m} / \mathrm{v})$ e tiossulfato de sódio 0,025 mol. $\mathrm{L}^{-1}$ para verificação da produção de ozônio pelo método iodométrico (adaptado de APHA, 2012).

\subsection{Experimentos de Cloração}

Os experimentos de oxidação com hipoclorito de sódio foram realizadas no LATAR e conduzidas em béqueres de bórax com capacidade de 2 litros, e submetidos a agitação mecânica (jar test).

Amostras de águas filtradas das ETAs de São Carlos e de Campinas foram analisadas para os parâmetros cloro total, cor aparente, turbidez e $\mathrm{pH}$, seguido de dopagem de 17ßestradiol em $6.000 \mathrm{ng} \mathrm{L}^{-1}$ e submetidas a diferentes condições de tempo de contato e dosagem de hipoclorito de sódio. Após alcançados os tempos de contato previamente estipulados, adicionou-se $1 \mathrm{~mL}$ de metabissulfito de sódio 3\% por litro de amostra para consumir o cloro residual presente.

Após essa etapa, todas as amostras foram tratadas de acordo com a metodologia analítica desenvolvida para avaliar a atividade estrogênica das amostras tratadas. 


\subsubsection{Método DPD}

As concentrações de cloro total das amostras foram determinadas pelo método clorototal, com a utilização de reagente para análise de cloro total de marca Hach. A metodologia do fabricante é uma adaptação de um método do Standard Methods for the Examination of Water and Wastewater (APHA, 2012). A leitura colorimétrica da solução foi realizada no espectrofotômetro Hach, modelo DR2800 no método de cloro total, reportando os resultados das análises em mg. $\mathrm{L}^{-1}$ de $\mathrm{Cl}_{2}$.

\subsection{Experimentos de Ozonização}

Os experimentos de oxidação com ozônio foram realizadas no LATAR. A unidade de ozonização, onde foram realizados os ensaios de oxidação com $\mathrm{O}_{3}$, consiste de três partes principais: o gerador de ozônio, o analisador de ozônio e a coluna de contato.

O gerador de ozônio, Figura 2, consiste em um sistema de bombeamento de ar, seguido da concentração do teor de oxigênio através de uma peneira molecular seguido da geração de ozônio em uma corona, resultando em uma corrente gasosa com concentração fixa de ozônio. Para medir concentração desse oxidante na fase gás na corrente de entrada coluna de contato, utilizou-se um analisador de ozônio de fabricante In USA Inc. modelo H1, Figura 3, sendo a medida feita por absorção na região do ultravioleta. 


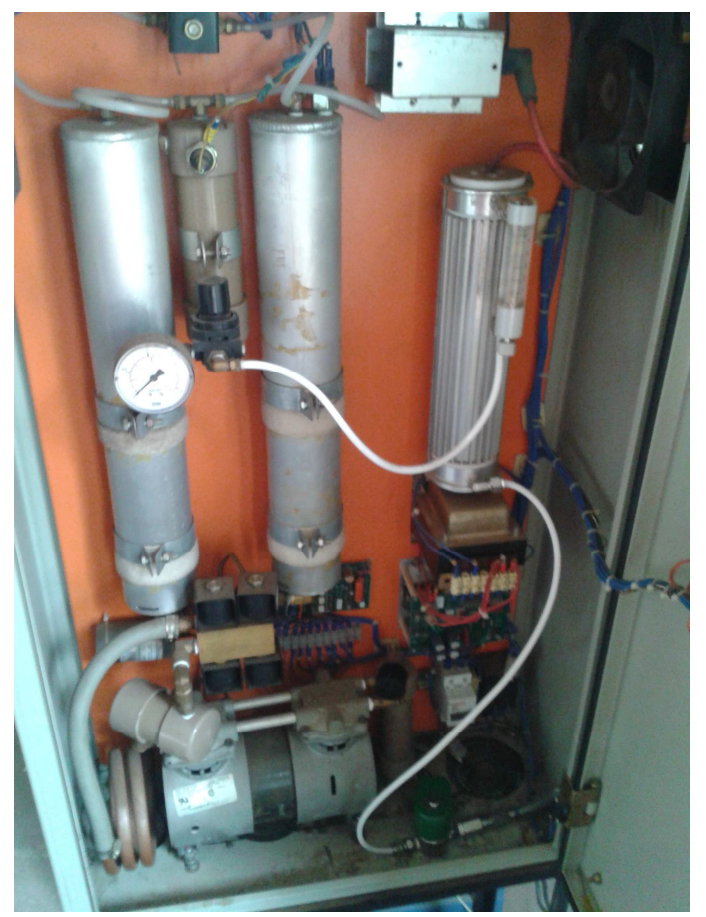

Figura 2 - Gerador de ozônio.

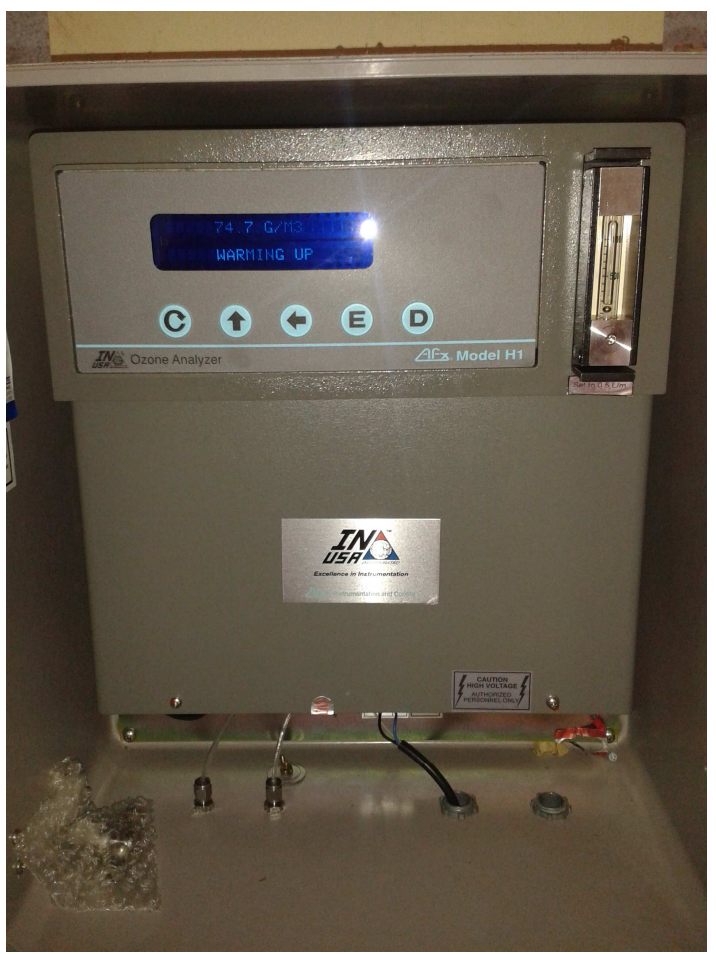

Figura 3 - Analisador de ozônio. 
Foi utilizada uma coluna de contato fabricada em acrílico com cerca de $230 \mathrm{~cm}$ de altura, $5 \mathrm{~cm}$ de diâmetro e volume de trabalho de 2,0 L. A corrente de ozônio foi continuamente introduzida na coluna de contato através de um difusor de pedra porosa, que gera bolhas, localizado na parte inferior das colunas. Na parte superior da coluna foi acoplado um sistema de coleta de off-gas, o qual consiste em um frasco contendo $500 \mathrm{~mL}$ de solução de iodeto de potássio $2 \%$, o qual lava a corrente de ar. A Figura 4 apresenta uma foto da unidade de ozonização.

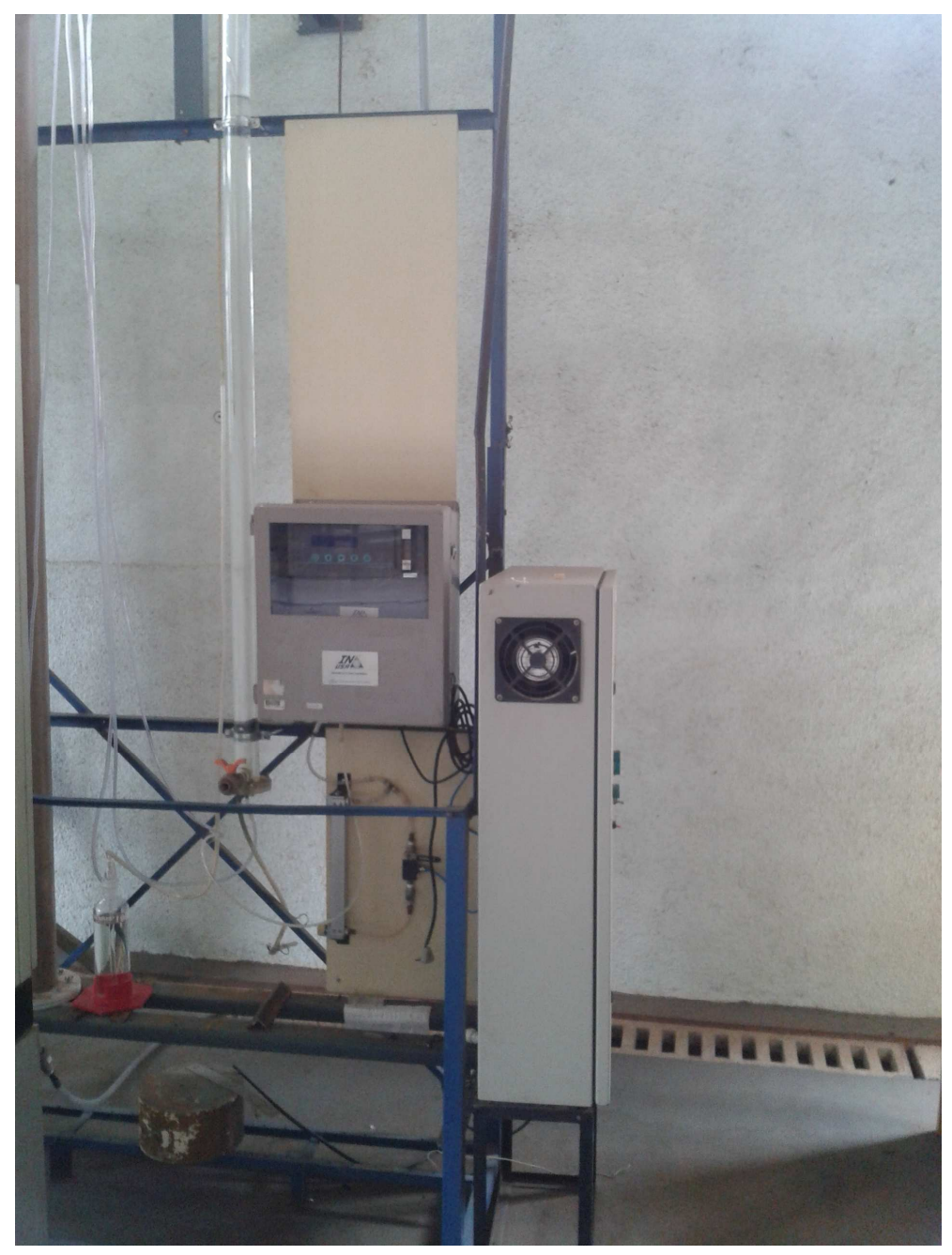

Figura 4 - Unidade de ozonização.

Amostras de águas filtradas das ETAs de São Carlos/SP e de Campinas/SP foram analisadas para os parâmetros cor aparente, turbidez e $\mathrm{pH}$, seguido de dopagem de $17 \beta$ - 
estradiol em $6.000 \mathrm{ng} \mathrm{L}^{-1}$. Essas amostras foram então submetidas à ozonização, que consiste em uma corrente contendo ozônio em uma concentração média de 50 g.m ${ }^{-3}$, introduzida continuamente na coluna de contato, com a vazão ajustada em $15 \mathrm{NL} . \mathrm{h}^{-1}$. Pela variação do tempo, dosagens diferentes de ozônio foram introduzidas nas amostras, variando de 0,5 a 2,0 mg. $\mathrm{L}^{-1}$ de $\mathrm{O}_{3}$. Depois de alcançada a dosagem desejada, o sistema de geração de ozônio era desligado, a solução devidamente homogeneizada e, depois de atingido os diferentes tempos de contato entre o agente oxidante e a amostra, o oxidante foi consumido com a adição de 1 $\mathrm{mL}$ de metabissulfito de sódio 3\% por litro de amostra para consumir o ozônio presente. Uma amostra de cada um dos ensaios foi retirada para a quantificação do ozônio residual pelo método de Índigo-Blue, bem como a titulação da solução de iodeto de potássio adicionada no off-gas (APHA, 2012).

Após essa etapa, todas as amostras foram tratadas de acordo com a metodologia analítica desenvolvida para avaliar a atividade estrogênica das amostras tratadas.

\subsubsection{Método Iodométrico}

Para realizar a aferição do equipamento de medição de ozônio na fase gasosa (ozônio contido na mistura de oxigênio e ozônio aplicado na coluna de contato), adicionou-se à coluna de contato 2,0 L de solução de Iodeto de Potássio 2\%. Após a submissão do sistema à ozonização nas condições dos experimentos, uma amostra foi analisada pelo método iodométrico, que consiste na acidificação da amostra com ácido sulfúrico e titulação com tiossulfato de sódio $0,025 \mathrm{~N}$, utilizando solução de amido como indicador. Para o cálculo da produção média de ozônio no sistema, utilizou-se a equação (1) 


$$
P_{\text {Coluna }}=\frac{N_{t} \times \Delta_{w t} \times V_{K I} \times 24000 \times 60}{V_{\text {am orra }} x t \times 1000}
$$

$P_{\text {coluna: }}$ produção de ozônio na coluna de contato $\left(\mathrm{g} \mathrm{O}_{3} \cdot \mathrm{h}^{-1}\right)$;

$N_{t}$ : normalidade do Tiossulfato de Sódio $\left(\mathrm{mol} . \mathrm{L}^{-1}\right)$;

$\Delta_{v t}$ : diferença entre o volume de solução de Tiossulfato de Sódio consumidos na titulação da amostra e do branco $(\mathrm{mL})$;

$V_{K I}$ : volume da solução de Iodeto de Potássio adicionado na coluna de contato (L);

$V_{\text {amostra: }}$ volume coletado de amostra para titulação $(\mathrm{mL})$;

$t$ : tempo de aplicação de ozônio na coluna de contato (min);

24000, 60, 1000: fatores de conversão de unidades;

Após a determinação de ozônio dentro da coluna de ozonização, pode-se calcular a dosagem de ozônio, em mg. $\mathrm{L}^{-1}$ pela equação (2)

$$
D_{\text {Coluna }}=\frac{p x t \times 1000}{V_{K I} \times 60}
$$

$D_{\text {coluna }}=$ dosagem de ozônio na coluna de contato $\left(\mathrm{mg} . \mathrm{L}^{-1}\right)$

$P=$ produção de ozônio na coluna de contato $\left(\mathrm{g} \mathrm{O}_{3} \cdot \mathrm{h}^{-1}\right)$;

$t$ : tempo de aplicação de ozônio na coluna de contato (min);

$V_{K I}$ : volume da solução de Iodeto de Potássio adicionado na coluna de contato (L);

1000, 60: fatores de conversão de unidades;

O procedimento descrito foi também aplicado na determinação das concentrações de off-gas nesse sistema e nos experimentos. 


\subsubsection{Método Índigo-Blue}

A concentração de ozônio residual na fase aquosa das amostras foram determinadas pelo método índigo-blue, com a utilização do kit Accu-Vac de marca Hach. A metodologia e kit do fabricante é uma adaptação de um método do Standard Methods for the Examination of Water and Wastewater (APHA, 2012). A leitura colorimétrica da solução foi realizada no espectrofotômetro Hach, modelo DR2800 no método de low range, reportando os resultados das análises em mg. $\mathrm{L}^{-1}$ de $\mathrm{O}_{3}$.

\subsection{Extração Por Fase Sólida (EFS)}

A EFS é uma ferramenta útil para extração e concentração de micropoluentes em amostras aquosas. Na EFS foram utilizados cartuchos de extração em fase de resina C18 de 500 mg e 3 mL de marca e BondElut (para BLYES), de fabricação da Agilent Technologies. Antes de passar a amostra pelos cartuchos, os mesmos foram sistematicamente condicionados pela lavagem com 3 X $2 \mathrm{~mL}$ de Hexano, seguido por 1 X $2 \mathrm{~mL}$ de Acetona e 3 X $2 \mathrm{~mL}$ de Metanol, por último $5 \times 2 \mathrm{~mL}$ de água ultrapura (Barnstead) em pH 3, com adição de ácido clorídrico. Em seguida, passou-se através dos cartuchos, numa taxa de $20 \mathrm{~mL} \cdot \mathrm{min}^{-1}, 1 \mathrm{~L}$ de amostra para análise por BLYES, sem correção de $\mathrm{pH}$, seguido por uma lavagem do cartucho com 5 X 2 mL de solução 1:9 de metanol com água ultrapura, para a retirada de possíveis contaminantes retidos nos cartuchos (adaptado de TERNES, 2003).

Os cartuchos para análise por BLYES foram encaminhados ao Laboratório do Setor de Análises Toxicológicas (ELTA) da CETESB para análise, o qual disponha da infraestrutura e tecnologia necessários para a realização deste ensaio. As etapas envolvidas na concentração da amostra por extração em fase sólida se resumem conforme a esquematizado na Figura 5. e o sistema de extração/eluição está apresentado na Figura 6, o qual utiliza um sistema a vácuo composto por um manifold, uma bomba a vácuo e diversas mangueiras para transportar a amostra para os cartuchos contendo resina C18. 
- Composto de interesse

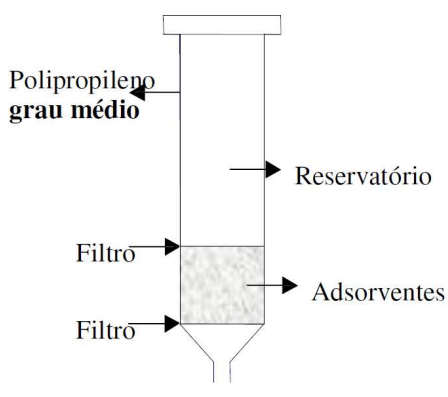

Condicionamento

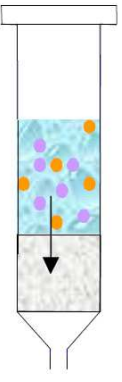

Adição da amostra
- Contaminante

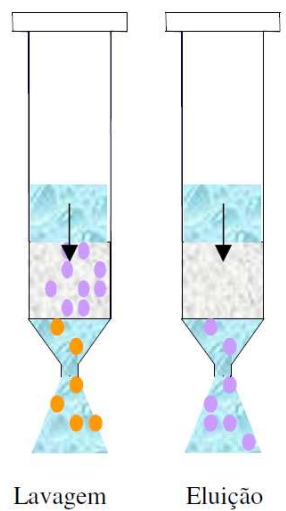

Figura 5 - Cartucho e principais etapas empregadas em EFS (Adaptado de Araújo, 2006).

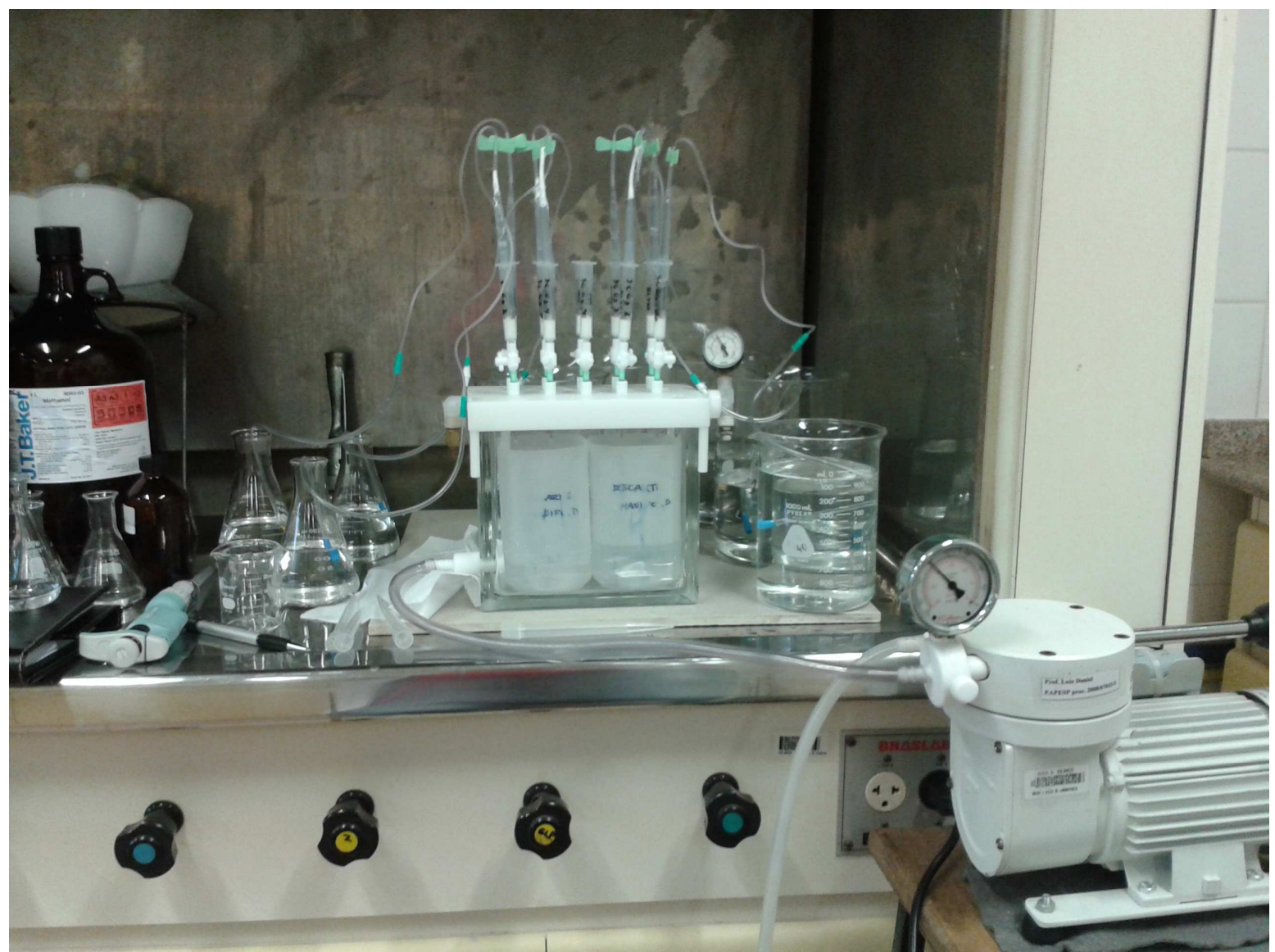

Figura 6 - Sistema de extração/eluição. 
O fluxograma das etapas da metodologia analítica utilizada para a determinação do $17 \beta$-estradiol e da atividade estrogênica estão apresentados na Figura 7.

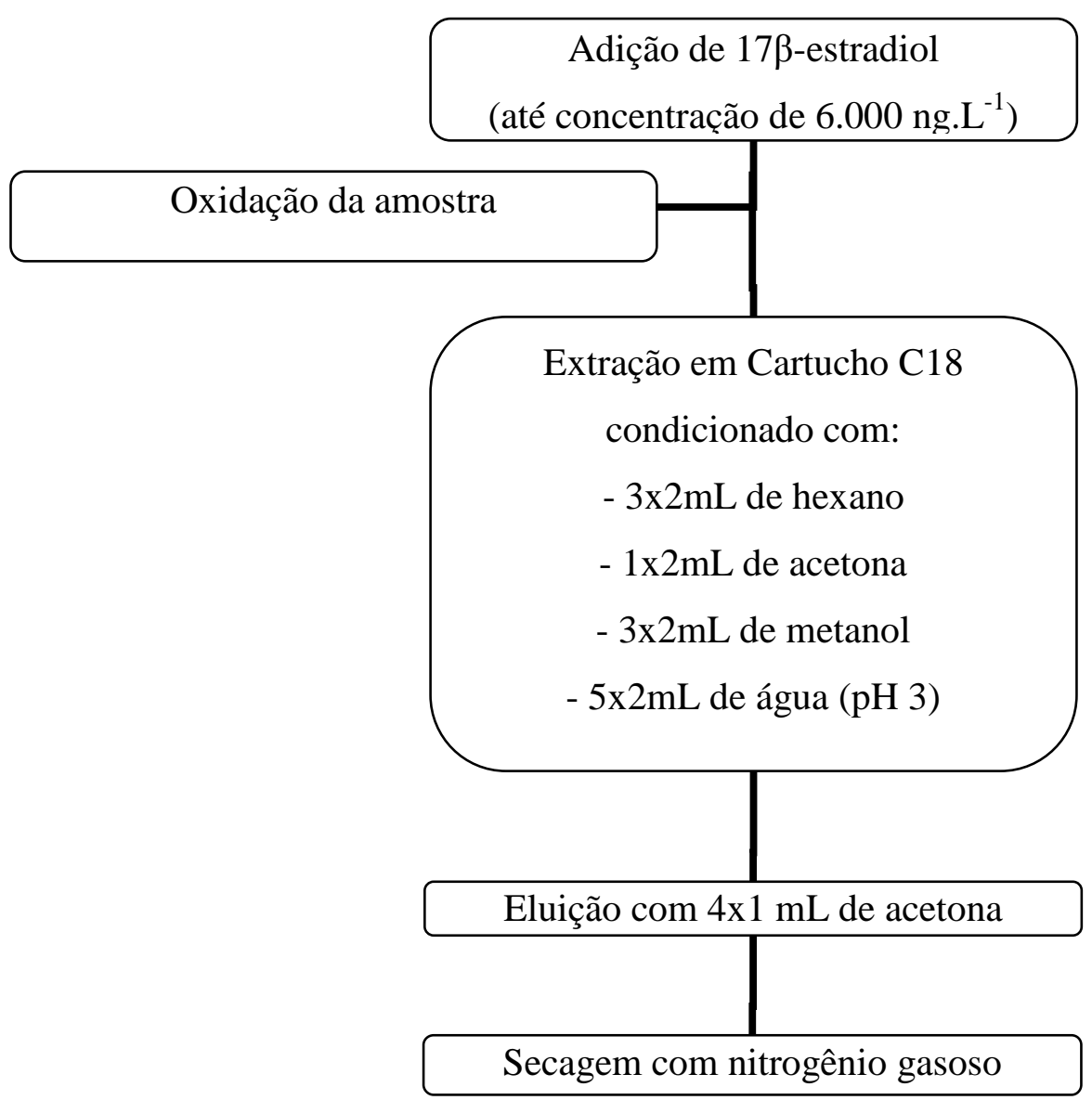

Figura 7 - Esquema da metodologia analítica utilizada na extração da amostra em EFS.

\subsection{Teste BLYES (Bioluminescent Yeast Estrogen Screen)}

A metodologia analítica utilizada nesta pesquisa foi desenvolvida por Sanseverino et al. (2005) a qual se baseia no emprego de Saccharomyces cerevisiae recombinante, que 
contêm o receptor de estrógeno humano (hER) e emite luz quando em contato com compostos estrogênicos.

Os ensaios in vitro foram realizados na CETESB utilizando um luminômetro Victor X3 contendo um dispensador de reagentes Flex Drop Plus, ambos da marca Perkin Elmer. Para a quantificação dos ensaios, utilizou-se o programa SigmaPlot ${ }^{\circledR}$.

Para o ensaio de atividade estrogênica, os mesmos extratos das amostras usados para a determinação química foram secos sob fluxo de $\mathrm{N}_{2}$ e, posteriormente, os analitos foram redissolvidos em solução de dimetilsulfóxido (DMSO) $1 \%$.

Os reagentes descritos também foram preparados na CETESB, seguindo o protocolo de Sanseverino et al. (2005). A vidraria utilizada em todas as etapas, desde a coleta até os ensaios, foi dedicada exclusivamente ao teste BLYES, conforme metodologia de coleta para pesticidas no Guia nacional de coleta e preservação de amostras: água, sedimento, comunidades aquáticas e efluentes líquidos (CETESB e ANA, 2011).

\subsubsection{Preparo de soluções e padrões}

O meio de cultura mínimo para o ensaio utilizado para a análise por BLYES, o qual é idêntico ao do YES (YMM), foi preparado com a adição de $1 \mathrm{~L}$ de água ultrapura, contendo os seguintes reagentes:

$13,61 \mathrm{~g}$ de $\mathrm{KH}_{2} \mathrm{PO}_{4}$;

$1,98 \mathrm{~g}$ de $\left(\mathrm{NH}_{4}\right)_{2} \mathrm{SO}_{4}$;

4,2 g de $\mathrm{KOH}, 0,2$ g de $\mathrm{MgSO}_{4}$; e

$1 \mathrm{~mL}$ de solução de $\mathrm{FeSO}_{4}$ a $0,8 \mathrm{~g} \mathrm{~L}^{-1}$.

Em seguida, a solução foi esterilizada por $10 \mathrm{~min}$ em autoclave a $121^{\circ} \mathrm{C}$. Finalmente foram adicionadas as seguintes soluções de aminoácidos, previamente esterilizadas nas mesmas condições descritas anteriormente: 
$50 \mathrm{~mL}$ de L- Histidina $10 \mathrm{~g} \mathrm{~L}^{-1}$;

$10 \mathrm{~mL}$ de adenina $5 \mathrm{~g} \mathrm{~L}^{-1}$;

$2 \mathrm{~mL}$ de L-arginina $10 \mathrm{~g} \mathrm{~L}^{-1}$;

$2 \mathrm{~mL}$ de L-metionina $10 \mathrm{~g} \mathrm{~L}^{-1}$;

$3 \mathrm{~mL}$ de L-tirosina $10 \mathrm{~g} \mathrm{~L}^{-1}$;

$3 \mathrm{~mL}$ de L-isoleucina $10 \mathrm{~g} \mathrm{~L}^{-1}$;

$2 \mathrm{~mL}$ de L-fenilalanina $10 \mathrm{~g} \mathrm{~L}^{-1}$;

2 mL de L-ácido glutâmico $50 \mathrm{~g} \mathrm{~L}^{-1}$;

$5 \mathrm{~mL}$ de L-valina $30 \mathrm{~g} \mathrm{~L}^{-1}$; e

$10 \mathrm{~mL}$ de L-serina $37,5 \mathrm{~g} \mathrm{~L}^{-1}$.

A solução de vitamina foi preparada em $500 \mathrm{~mL}$ de água ultrapura pela adição dos seguintes reagentes, seguido de filtração da solução em membrana de $0,22 \mu \mathrm{m}$ e conservação em refrigerador:

20 mg de tiamina Sigma;

20 mg de piridoxina;

20 mg de ácido Pantotenico;

100 mg de inositol; e

$50 \mathrm{~mL}$ de biotina $0,02 \mathrm{~g} \mathrm{~L}^{-1}$.

Para o preparo de $1 \mathrm{~L}$ de meio de crescimento (YMMG) foi feita a mistura das seguintes soluções:

854,5 mL de meio mínimo;

$10 \mathrm{~mL}$ de solução de vitamina; 
$100 \mathrm{~mL}$ de solução de glicose $20 \%$;

$25 \mathrm{~mL}$ de solução de ácido aspártico $4 \mathrm{~g} \mathrm{~L}^{-1}$;

$8 \mathrm{~mL}$ de solução de treonina $24 \mathrm{~g} \mathrm{~L}^{-1}$; e

2,5 mL de solução de sulfato de cobre (II) $10 \mathrm{~g} \mathrm{~L}^{-1}$.

Em seguida a solução foi filtrada em membrana de $0,22 \mu \mathrm{m}$. Para o meio utilizado em placa, adicionou-se 1,3 g de Agar Nobre por litro de solução do meio YMMG. Para os ensaios, 18 soluções foram preparadas em placas, com concentrações que variaram na ordem de $10^{-13}$ a $10^{-7} \mathrm{~mol} \mathrm{~L}^{-1}$ de E2 e $50 \mu \mathrm{L}$ de cultura.

Culturas estoque de E2 foram preparadas adicionando-se $50 \%$ de solução de glicerol $40 \%$ em ampolas de $2 \mathrm{~mL}$, sendo, em seguida, armazenadas em freezer a $-70{ }^{\circ} \mathrm{C}$.

Para o cultivo das cepas, linhagens de Saccharomyces cerevisiae BLYES (responsiva e quantitativa a estrógeno) e BLYR (controle de toxicidade, apresentando resposta positiva quanto o meio é favorável ao crescimento da levedura), obtidas a partir de culturas congeladas, foram colocadas para crescer em um frasco de vidro contendo $30 \mathrm{~mL}$ de meio mínimo. A solução foi mantida sob agitação em shaker a $250 \mathrm{rpm}$, até atingir densidade óptica de 1 em $600 \mathrm{~nm}\left(\mathrm{DO}_{600}\right)$, que ocorreu em cerca de $22 \mathrm{~h}$, a $30{ }^{\circ} \mathrm{C}$.

\subsubsection{Análises das amostras}

Um dia antes dos ensaios, as linhagens foram descongeladas e rapidamente transferidas para um frasco contendo $30 \mathrm{~mL}$ de YMMG. As culturas foram agitadas até atingir $\mathrm{DO}_{600}$ (densidade óptica a $600 \mathrm{~nm}$ ) próximo a 1. Em seguida, as culturas foram diluídas em volumes apropriados de meio de crescimento para se obter uma solução final com $\mathrm{DO}_{600}$ igual a 4. Finalmente, $50 \mu \mathrm{L}$ das culturas foram transferidos para os orifícios das micro-placas.

Todos os ensaios foram realizados com uma placa contendo a linhagem BLYES e outra placa com a linhagem BLYR. As placas foram então agitadas em vórtex por $20 \mathrm{~s}$ e então incubadas a $30{ }^{\circ} \mathrm{C}$. Foi realizada medida de luminescência das microplacas em luminômetro 
após $3 \mathrm{~h}$ de incubação. Para os extratos, foram feitas 9 diluições seriadas partindo de uma solução 100 vezes concentrada das amostras. Foram dosados $100 \mu \mathrm{L}$ de amostra por poço em microplaca de 96 poços, assim como $100 \mu \mathrm{L}$ dos controles negativos (DMSO $1 \%$ ) e positivo (E2), conforme Figura 8.

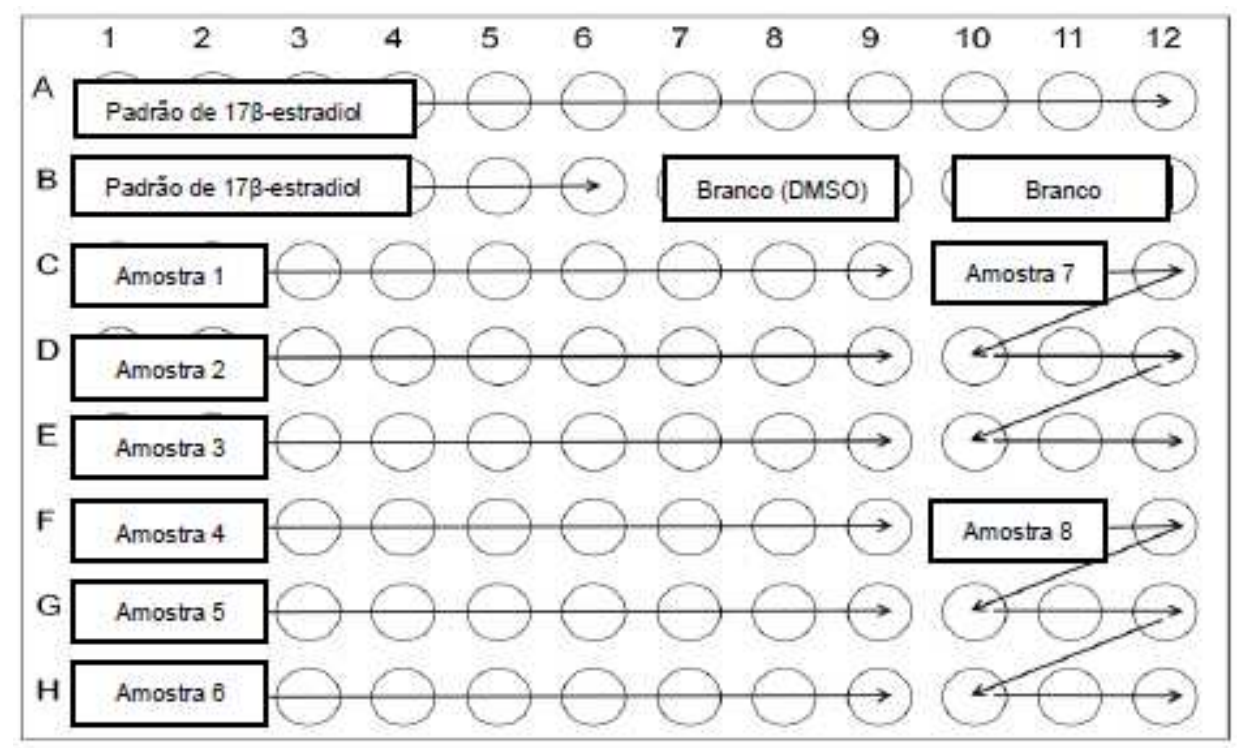

Figura 8 - Mapa da microplaca indicando a distribuição dos controles, amostras e padrão de E2 no ensaio BLYES (adaptado de ELDRIDGE et al., 2011).

O critério de positividade para as amostras em termos de atividade estrogênica significativa foi a média da resposta do controle negativo, contendo cultura de leveduras com solução de solvente DMSO $1 \%$, mais três vezes o desvio padrão $(\mathrm{n}=6)$. A concentração efetiva $50 \%\left(\mathrm{CE}_{50}\right)$ dos compostos foi calculada avaliando-se o ponto médio da porção linear da curva dose resposta, considerando a resposta mínima dos controles negativos (SANSEVERINO et al., 2009). O limite de detecção (LD) adotado para o método foi a concentração de E2 capaz de provocar efeito igual ao critério de positividade.

As leituras de luminescência obtidas com a linhagem BLYES foram corrigidas no caso de existir toxicidade com a linhagem BLYR, desde que a toxicidade desta não fosse maior que 1,5 (razão entre a luminescência de background e a luminescência da amostra). Para estes casos, as medidas foram repetidas em concentrações menores ou desconsideradas. As curvas 
dose e resposta foram construídas com dados de medida de luminescência obtidas para diferentes diluições das amostras, sendo normalizadas em termos de porcentagem de resposta máxima de E2. Os resultados observados no luminômetro Victor X3 foram tratados no programa SigmaPlot ${ }^{\circledR}$. A Figura 9 ilustra os procedimentos de expressão e detecção da atividade estrogênica.

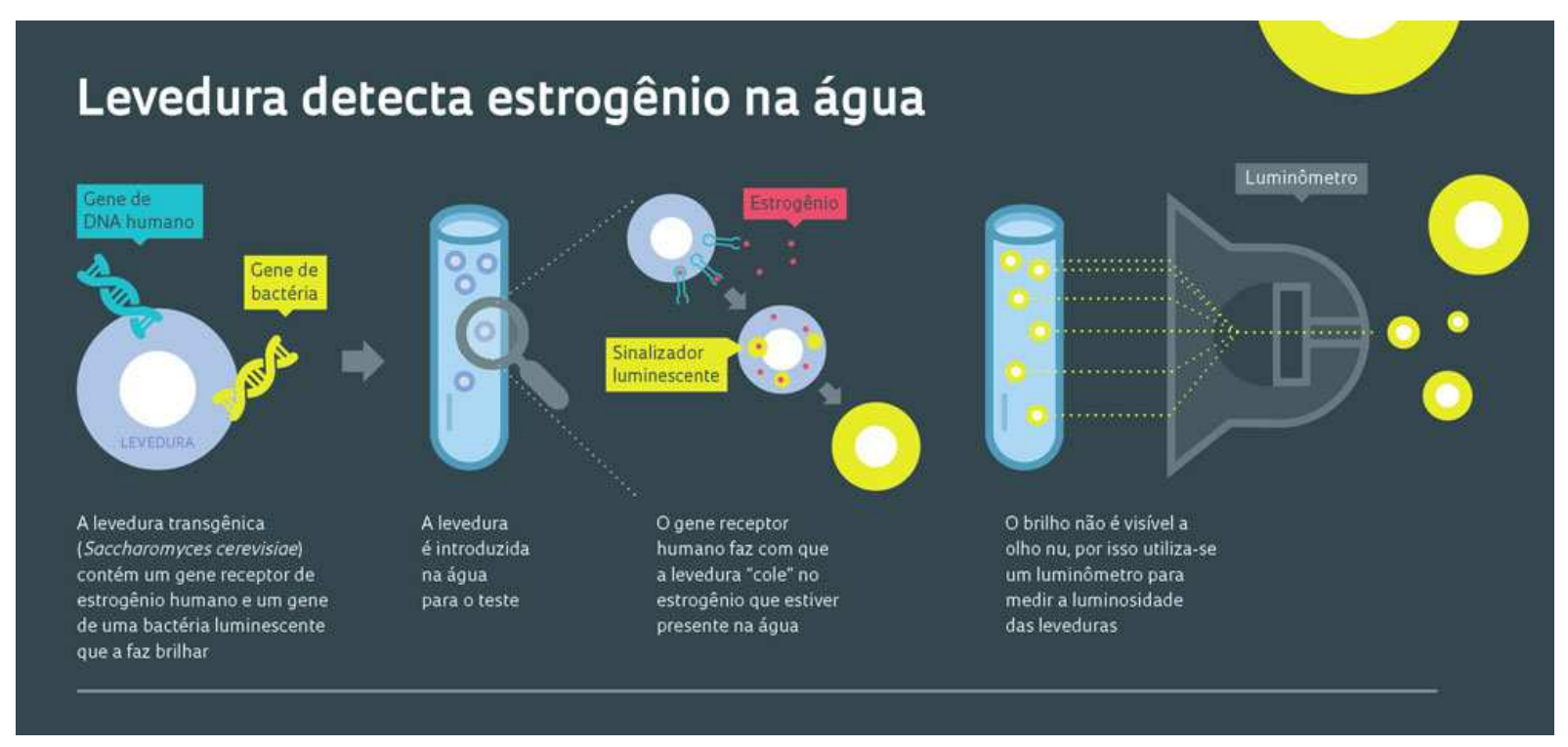

Figura 9 - Processos de expressão e detecção de luminescência do teste BLYES

(VASCONCELOS, 2012).

\subsubsection{Tratamento dos dados}

Com os valores das leituras de absorbância, os resultados foram tratados no programa SigmaPlot ${ }^{\circledR}$, o qual gerou os gráficos sigmoidais, encontrou os pontos máximos, mínimos e médios do padrão de E2, calculou o logaritmo do ponto médio, a equação da reta (bem como seus coeficientes angular e linear), seu coeficiente de correlação e os valores de $\mathrm{CE}_{50}$ e concentração molar $\left(m o l . L^{-1}\right)$ e em ngE2equiv. $L^{-1}$. Os itens citados encontram-se demonstrados na Figura 10 apresentada por Bila (2005) e reproduzida por Fischer (2013): 


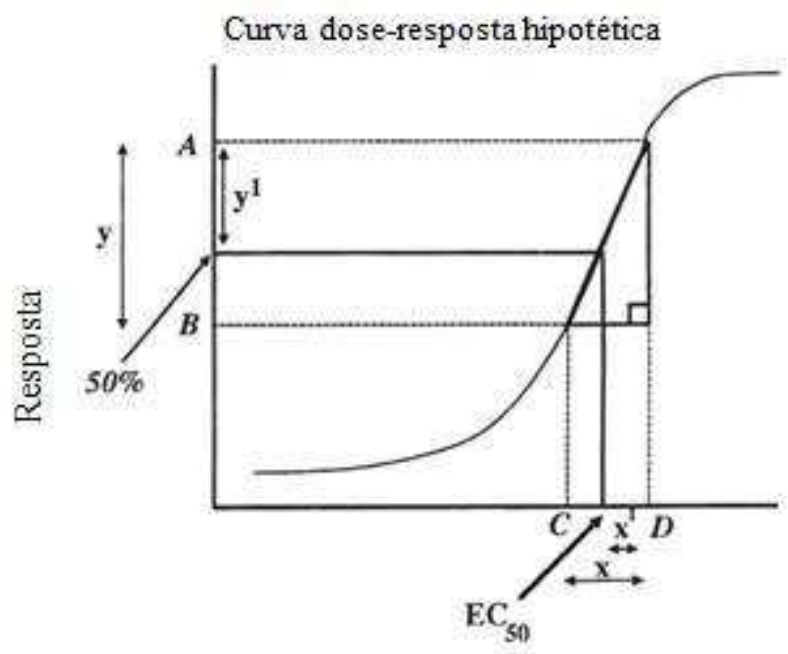

Concentração da droga

Figura 10 - Gráfico retirado de Fisher (2013), ilustrando os pontos utilizados para o cálculo do $\mathrm{CE}_{50}$. 


\section{RESULTADOS E DISCUSSÃO}

\subsection{Ensaios de Cloração}

Os ensaios de cloração foram conduzidos em diferentes concentrações e de tempos, usualmente utilizados em estações de tratamento de água convencionais, em triplicata nas amostras de água filtradas estudadas.

\subsubsection{ETA de São Carlos (SAAE)}

A ETA de São Carlos realiza tratamento das águas captadas do Córrego Espraiado e do Ribeirão Feijão, realizando operações unitárias de tratamento o tratamento por ciclo completo que inclui: coagulação, floculação, decantação, filtração, cloração e fluoretação, com as devidas correções de $\mathrm{pH}$ em cada uma das etapas.

Foi coletada, em 19/01/2013 (período de chuvas), uma amostra de cerca de $10 \mathrm{~L}$ de água filtrada dessa estação com as seguintes características: cor aparente $1 \mathrm{mg} . \mathrm{L}^{-1} \mathrm{Pt}-\mathrm{Co}$; turbidez 0,70 UNT; pH 6,9; e cloro total <0,05 mg. $\mathrm{L}^{-1}$.

Após a realização dessas análises, a amostra foi dividida em frações de 1,4 L, fortificadas com 17ß-estradiol e submetidas a duas diferentes condições de cloração: cloro total inicial de $0,39 \mathrm{mg} . \mathrm{L}^{-1}$, por $10 \mathrm{~min}$; e cloro total inicial de $1,38 \mathrm{mg} . \mathrm{L}^{-1}$, por $30 \mathrm{~min}$.

Observou-se que nos ensaios com quantidades menores de hipoclorito de sódio adicionadas, após transcorridos os 10 min de reação, o cloro residual caiu de $0,39 \mathrm{mg} . \mathrm{L}^{-1}$ para 0,28 mg. $\mathrm{L}^{-1}$, enquanto que para os maiores caiu de $1,38 \mathrm{mg} \cdot \mathrm{L}^{-1}$ para $0,60 \mathrm{mg} . \mathrm{L}^{-1}$, após os 30 min. Observou-se, também, que o pH final das soluções caiu para 6,3.

Dessa forma, verificou-se uma demanda significativa por cloro, sobretudo nas replicatas de maiores dosagens do agente oxidante. A Tabela 1 reporta as condições variáveis do experimento. 
Tabela 1 - Condições experimentais nos ensaios de cloração de água da ETA de São Carlos

\begin{tabular}{ccccc}
\hline Ensaio & $\begin{array}{c}\text { Concentração de } \\
\mathbf{1 7 \beta} \text {-estradiol }\end{array}$ & $\begin{array}{c}\text { Tempo de } \\
\text { contato (min) }\end{array}$ & $\begin{array}{c}\text { Concentração de } \\
\text { cloro total } \\
\text { aplicado }\left(\mathbf{m g L}^{-\mathbf{1}}\right)\end{array}$ & $\begin{array}{c}\text { Concentração de } \\
\text { cloro total } \\
\text { residual }\left(\mathbf{m g L}^{-\mathbf{1}}\right)\end{array}$ \\
$\mathrm{SC} \mathrm{Cl}_{2} 1$ & & 10 & 0,39 & 0,28 \\
$\mathrm{SC} \mathrm{Cl}_{2}$ & & 10 & 0,39 & 0,28 \\
$\mathrm{SC} \mathrm{Cl}_{2} 3$ & $6.000 \mathrm{ngL}^{-1}$ & 10 & 0,39 & 0,28 \\
$\mathrm{SC} \mathrm{Cl}_{2} 4$ & & 30 & 1,38 & 0,60 \\
$\mathrm{SC} \mathrm{Cl}_{2} 5$ & & 30 & 1,38 & 0,60 \\
$\mathrm{SC} \mathrm{Cl}_{2} 6$ & & 30 & 1,38 & 0,60 \\
\hline
\end{tabular}

\subsubsection{ETAs 3 e 4 de Campinas (SANASA)}

As ETAs 3 e 4 de Campinas tratam a água captada do rio Atibaia, tratam a água pelo tratamento de ciclo completo que inclui: pré cloração, coagulação, floculação, decantação, filtração, cloroamoniação e fluoretação, com as devidas correções de pH em cada uma das etapas.

Foi coletada, em 01/02/2013 (período de chuvas), uma amostra de cerca de $10 \mathrm{~L}$ de água filtrada dessa estação com as seguintes características: cor aparente $<1 \mathrm{mg} . \mathrm{L}^{-1} \mathrm{Pt}-\mathrm{Co}$; turbidez 0,14 UNT; pH 7,1; e cloro total 0,76 mg.L ${ }^{-1}$.

Após a realização dessas análises, a amostra foi dividida em frações de 1,4 L, fortificadas com 17ß-estradiol e submetidas a duas diferentes condições de ensaio de cloração: cloro total inicial de $0,76 \mathrm{mg} . \mathrm{L}^{-1}$, por $10 \mathrm{~min}$; e cloro total inicial de $1,18 \mathrm{mg} . \mathrm{L}^{-1}$, por 30 min. Nas triplicatas de menores concentrações de cloro não foram adicionado hipoclorito de sódio, devido a presença de cloro livre na amostra. 
Observou-se que nos ensaios com quantidades menores de cloro, após transcorridos os 10 min de reação, o cloro residual caiu de $0,76 \mathrm{mg} . \mathrm{L}^{-1}$ para $0,68 \mathrm{mg} . \mathrm{L}^{-1}$, enquanto que para os maiores caiu de 1,18 mg. $\mathrm{L}^{-1}$ para 1,12 mg. $\mathrm{L}^{-1}$, após os $30 \mathrm{~min}$. Observou-se, também, que o pH final das soluções não foi alterado após os ensaios.

Dessa forma, verificou-se uma demanda pouco significativa por cloro. A Tabela 2 reporta as condições variáveis do experimento.

Tabela 2 - Condições experimentais nos ensaios de cloração de água da ETAs 3 e 4 de Campinas

\begin{tabular}{ccccc}
\hline Ensaio & $\begin{array}{c}\text { Concentração de } \\
\mathbf{1 7 \beta} \text {-estradiol }\end{array}$ & $\begin{array}{c}\text { Tempo de } \\
\text { contato }(\mathbf{m i n})\end{array}$ & $\begin{array}{c}\text { Concentração de } \\
\text { cloro total } \\
\text { aplicado }\left(\mathbf{m g L}^{-\mathbf{1}}\right)\end{array}$ & $\begin{array}{c}\text { Concentração de } \\
\text { cloro total } \\
\text { residual }\left(\mathbf{m g L}^{-\mathbf{1}}\right)\end{array}$ \\
$\mathrm{CPS} \mathrm{Cl}_{2} 1$ & & 10 & 0,76 & 0,69 \\
$\mathrm{CPS} \mathrm{Cl}_{2} 2$ & & 10 & 0,76 & 0,69 \\
$\mathrm{CPS} \mathrm{Cl}_{2} 3$ & $6.000 \mathrm{ngL}^{-1}$ & 10 & 0,76 & 0,69 \\
$\mathrm{CPS} \mathrm{Cl}_{2} 4$ & & 30 & 1,18 & 1,12 \\
$\mathrm{CPS} \mathrm{Cl}_{2} 5$ & & 30 & 1,18 & 1,12 \\
$\mathrm{CPS} \mathrm{Cl}$ & & 30 & 1,18 & 1,12 \\
\hline
\end{tabular}

\subsection{Ensaios de Ozonização}

Os ensaios de ozonização das amostras de água filtradas das ETAs foram conduzidos em diferentes concentrações do agente oxidante e de tempo, em duplicata.

Como se pode ver a seguir, assim como Pereira (2011) verificou, o residual de ozônio na fase líquida estava próximo ao limite de detecção do método Índigo (APHA, 2012) e foi praticamente desprezível nos cálculos do ozônio consumido. Outra importante observação é que a taxa de aplicação do ozônio varia com o tempo de contato. Pode-se observar variação na taxa de aplicação de ozônio para as mesmas condições, porque os experimentos foram 
realizados em batelada, portanto expostos a variações como temperatura, variação de tensão da rede elétrica que alimenta o gerador e outros.

\subsubsection{ETA de São Carlos (SAAE)}

Foi coletada, em 12/04/2013 (início da estiagem), uma amostra de cerca de $10 \mathrm{~L}$ de água filtrada dessa estação com as seguintes características: cor aparente $1 \mathrm{mg} . \mathrm{L}^{-1} \mathrm{Pt}-\mathrm{Co}$; turbidez 0,65 UNT; pH 6,2; e cloro total < 0,05 mg. $\mathrm{L}^{-1}$.

Após a realização dessas análises, a amostra foi dividida em frações de 2,0 L, enriquecidas com 17ß-estradiol e submetidas a duas diferentes condições de ozonização: aplicação de 5 segundos de ozônio, acarretando em adição $0,5 \mathrm{mg} . \mathrm{L}^{-1}$ de $\mathrm{O}_{3}$ (considerando uma vazão de 15 NL.h ${ }^{-1}$ e uma produção de ozônio de $50 \mathrm{~g} \mathrm{O}_{3} \cdot \mathrm{h}^{-1}$ ), seguido de um tempo de contato de $10 \mathrm{~min}$; e aplicação de 20 segundos de ozônio, acarretando em adição 2,0 mg.L $\mathrm{L}^{-1}$ de $\mathrm{O}_{3}$ (considerando as mesmas vazão e produção de ozônio mencionadas acima), seguido de um tempo de contato de 30 min.

Ao final dos ensaios de ozonização, verificou-se que o ozônio residual na amostra encontrava-se próximo a "zero" em todos os ensaios. Foi observado, também, que a quantidade de ozônio retida no off gas é inferior à dosagem teórica aplicada. Com os valores teórico de ozônio aplicado e com o valor de ozônio retido no off gas, por subtração do primeiro pelo segundo, obtém-se o ozônio consumido. Parte do ozônio aplicado pode ter sido consumido pela amostra e/ou ter permanecido em sua forma gasosa no interior da coluna de ozonização. Esses valores podem ser verificados na Tabela 3. 
Tabela 3 - Condições experimentais nos ensaios de ozonização de água da ETA de São Carlos

\begin{tabular}{|c|c|c|c|c|c|c|}
\hline Ensaio & $\begin{array}{c}\text { Concentração } \\
\text { de 17ß- } \\
\text { estradiol }\end{array}$ & $\begin{array}{c}\text { Tempo } \\
\text { de } \\
\text { contato } \\
\text { (min) }\end{array}$ & $\begin{array}{l}\text { Concentração } \\
\text { de ozônio } \\
\text { aplicado } \\
\left(\mathrm{mgL}^{-1}\right)\end{array}$ & $\begin{array}{c}\text { Concentração } \\
\text { de ozônio } \\
\text { residual } \\
\left(\mathrm{mgL}^{-1}\right)\end{array}$ & $\begin{array}{c}\text { Ozônio } \\
\text { Presente } \\
\text { no off } \\
\text { gas }(\mathbf{m g})\end{array}$ & $\begin{array}{c}\text { Ozônio } \\
\text { Consumido } \\
\text { (mg) }\end{array}$ \\
\hline $\mathrm{SC} \mathrm{O}_{3} 1$ & \multirow{4}{*}{$6.000 \mathrm{ngL}^{-1}$} & 30 & 2,0 & 0,04 & 0,61 & 3,39 \\
\hline $\mathrm{SC} \mathrm{O}_{3} 2$ & & 30 & 2,0 & 0,04 & 0,46 & 3,54 \\
\hline $\mathrm{SC} \mathrm{O}_{3} 3$ & & 10 & 0,5 & 0,01 & 0,31 & 0,69 \\
\hline $\mathrm{SC} \mathrm{O}_{3} 4$ & & 10 & 0,5 & 0,03 & 0,46 & 0,54 \\
\hline
\end{tabular}

\subsubsection{ETAs 3 e 4 de Campinas (SANASA)}

Foi coletada, em 17/04/2013 (início da estiagem), uma amostra de cerca de 10 L de água filtrada dessa estação com as seguintes características: cor aparente $<1 \mathrm{mg} . \mathrm{L}^{-1} \mathrm{Pt}-\mathrm{Co}$; turbidez 0,16 UNT; pH 6,8; e cloro total 1,32 mg. $\mathrm{L}^{-1}$. Após a coleta da amostra, adicionou-se Metabissulfito de Sódio $3 \%(\mathrm{~m} / \mathrm{v})$ até a concentração de cloro total chegasse em $<0,05 \mathrm{mg} . \mathrm{L}^{-1}$, para que a amostra não apresentasse excesso daquele agente redutor.

Após a realização dessas análises, a amostra foi dividida em frações de 2,0 L, fortificadas com 17ß-estradiol e submetidas a duas diferentes condições de ozonização: aplicação de 5 segundos de ozônio, acarretando em adição $0,5 \mathrm{mg} . \mathrm{L}^{-1}$ de $\mathrm{O}_{3}$ (considerando uma vazão de $15 \mathrm{NL} \cdot \mathrm{h}^{-1}$ e uma produção de ozônio de $50 \mathrm{~g} \mathrm{O}_{3} \cdot \mathrm{h}^{-1}$ ), seguido de um tempo de contato de 10 min; e aplicação de 20 segundos de ozônio, acarretando em adição 2,0 mg.L $\mathrm{L}^{-1}$ de $\mathrm{O}_{3}$ (considerando as mesmas vazão e produção de ozônio mencionadas acima), seguido de um tempo de contato de $30 \mathrm{~min}$.

Ao final dos ensaios de ozonização, verificou-se que o ozônio residual na amostra encontrava-se próximo a "zero" em todos os ensaios. Foi observado, também, que a quantidade de ozônio retida no off gas é inferior à dosagem teórica aplicada. Com os valores teórico de ozônio aplicado e com o valor de ozônio retido no off gas, por subtração do primeiro pelo segundo, obtém-se o ozônio consumido. Parte do ozônio aplicado pode ter sido 
consumido pela amostra e/ou ter permanecido em sua forma gasosa no interior da coluna de ozonização. Esses valores podem ser verificados na Tabela 4.

Tabela 4 - Condições experimentais nos ensaios de ozonização de água da ETAs 3 e 4 de Campinas

\begin{tabular}{|c|c|c|c|c|c|c|}
\hline Ensaio & $\begin{array}{c}\text { Concentração } \\
\text { de 17ß- } \\
\text { estradiol }\end{array}$ & $\begin{array}{c}\text { Tempo } \\
\text { de } \\
\text { contato } \\
\text { (min) }\end{array}$ & $\begin{array}{l}\text { Concentração } \\
\text { de ozônio } \\
\text { aplicado } \\
\left(\mathrm{mgL}^{-1}\right)\end{array}$ & $\begin{array}{c}\text { Concentração } \\
\text { de ozônio } \\
\text { residual } \\
\left(\mathrm{mgL}^{-1}\right)\end{array}$ & $\begin{array}{c}\text { Ozônio } \\
\text { Presente } \\
\text { no off } \\
\text { gas }(\mathrm{mg})\end{array}$ & $\begin{array}{c}\text { Ozônio } \\
\text { Consumido } \\
\text { (mg) }\end{array}$ \\
\hline $\mathrm{CPS} \mathrm{O}_{3} 1$ & \multirow{4}{*}{$6.000 \mathrm{ngL}^{-1}$} & 30 & 2,0 & 0,04 & 1,53 & 2,47 \\
\hline $\mathrm{CPS} \mathrm{O}_{3} 2$ & & 30 & 2,0 & 0,04 & 2,29 & 1,71 \\
\hline $\mathrm{CPS} \mathrm{O}_{3} 3$ & & 10 & 0,5 & 0,01 & 0,77 & 0,23 \\
\hline $\mathrm{CPS} \mathrm{O}_{3} 4$ & & 10 & 0,5 & 0,03 & 0,77 & 0,23 \\
\hline
\end{tabular}

\subsection{Atividade estrogênica das amostras}

Bioensaios estrogênicos e androgênicos in vitro baseados em leveduras tem se estabelecido com uma ferramenta rápida e prática para quantificação da atividade estrogênica de substâncias ou amostras. Um interferente endócrino, como é o caso do $17 \beta$-estradiol, pode agir de diversas maneiras e comprometer a saúde, sobretudo o desenvolvimento e o sistema reprodutor. A linhagem de levedura usada neste trabalho, que utiliza uma proteína de receptor humano e elementos de resposta para ativar a transcrição do gene repórter, não é capaz de identificar um interferente endócrino específico, uma vez que as leveduras não possuem sistema endócrino. Dessa forma, estudos in vivo se fazem necessários para elucidar, em detalhes, os efeitos provocados por compostos interferentes endócrinos no organismo. Ainda assim, os ensaios de BLYES têm sido usados como uma ferramenta de screening inicial para a determinação da atividade estrogênica de um composto ou amostra em diversos trabalhos científicos, principalmente para verificar a remoção da estrogenicidade de uma amostra após algum tratamento específico (SANSEVERINO et al., 2009). 
Com o uso do software SigmaPlot ${ }^{\circledR}$, foi calculada a atividade estrogênica a partir dos gráficos plotados da intensidade de bioluminescência (contagem por segundo - CPS) versus o logaritmo da concentração (fator de concentração ou concentração molar - $\log \mathrm{M}$ ) para as cepas de BLYES. Foi calculada a $\mathrm{CE}_{50}$, a partir do ponto médio da parte linear da curva doseresposta destes ensaios. As amostras foram consideradas positivas quando apresentaram aumento da luminescência em pelo menos 3 concentrações, de forma a tornar possível a realização de regressão linear. O resultado foi expresso em nanogramas equivalentes de E2 por litro de amostra (ngE2equiv $\left.\mathrm{L}^{-1}\right)$, sendo este o quociente entre o $\mathrm{CE}_{50}$ do $\mathrm{E} 2$ e o $\mathrm{CE}_{50}$ da amostra, calculado com base na regressão linear. Para o controle positivo do ensaio, a fim de verificar que não há inibição da expressão da levedura, as amostras foram também expostas às cepas de BLYR.

Foi estabelecida a concentração teórica de 6.000 ngE2equiv $\mathrm{L}^{-1}$, pela contaminação

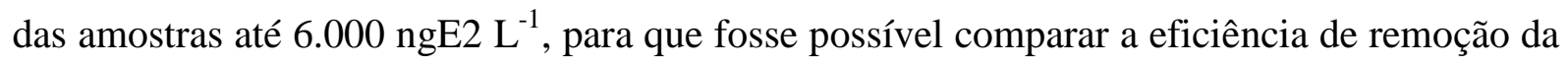
atividade estrogênica entre a oxidação por cloro e ozônio, submetendo-se as amostras a diferentes concentrações dos agentes oxidantes e de tempo, como elucidado nos itens 5.1. e 5.2. .

\subsection{Amostras contaminadas com 17 $\beta$-estradiol e tratadas com cloro}

Após a etapa de concentração das amostras nos cartuchos C-18, estes foram armazenados sob refrigeração até sua análise no laboratório do Setor de Análises Toxicológicas da CETESB. O transporte dos cartuchos entre as cidades de São Carlos - SP e São Paulo - SP também foi conduzido sob refrigeração.

As variáveis que influenciam o resultado da atividade estrogênica nos ensaios de oxidação com cloro consistem em, basicamente: concentração de $17 \beta$-estradiol, concentração aplicada de cloro e tempo de contato. Outros fatores, como demanda da matriz pelo agente oxidante pode ser relevante.

As Figuras de curva dose-resposta de 17ß-estradiol e das amostras (intensidade de bioluminescência versus concentração molar) foram disponibilizada pela CETESB, obtida para o ensaio BLYES (atividade estrogênica) e BLYR (toxicidade). 
A curva padrão de $17 \beta$-estradiol resultante do ensaio no laboratório do Setor de Análises Toxicológicas da CETESB (Figura 11) na batelada para determinação da atividade estrogênica das amostras tratadas com cloro apresenta o formato sigmoidal, o que atende ao esperado, pois é na inflexão da curva que se obtém a concentração equivalente de E2, conforme esquema da Figura 10. Obteve-se também uma ampla faixa de luminescência, expressa em CPS (contagens por segundo), o que era esperado e está de acordo com os resultados obtidos por Jardim (2012), Eldridge et al., (2011), Raimundo (2011) e Sanseverino et al., (2009).

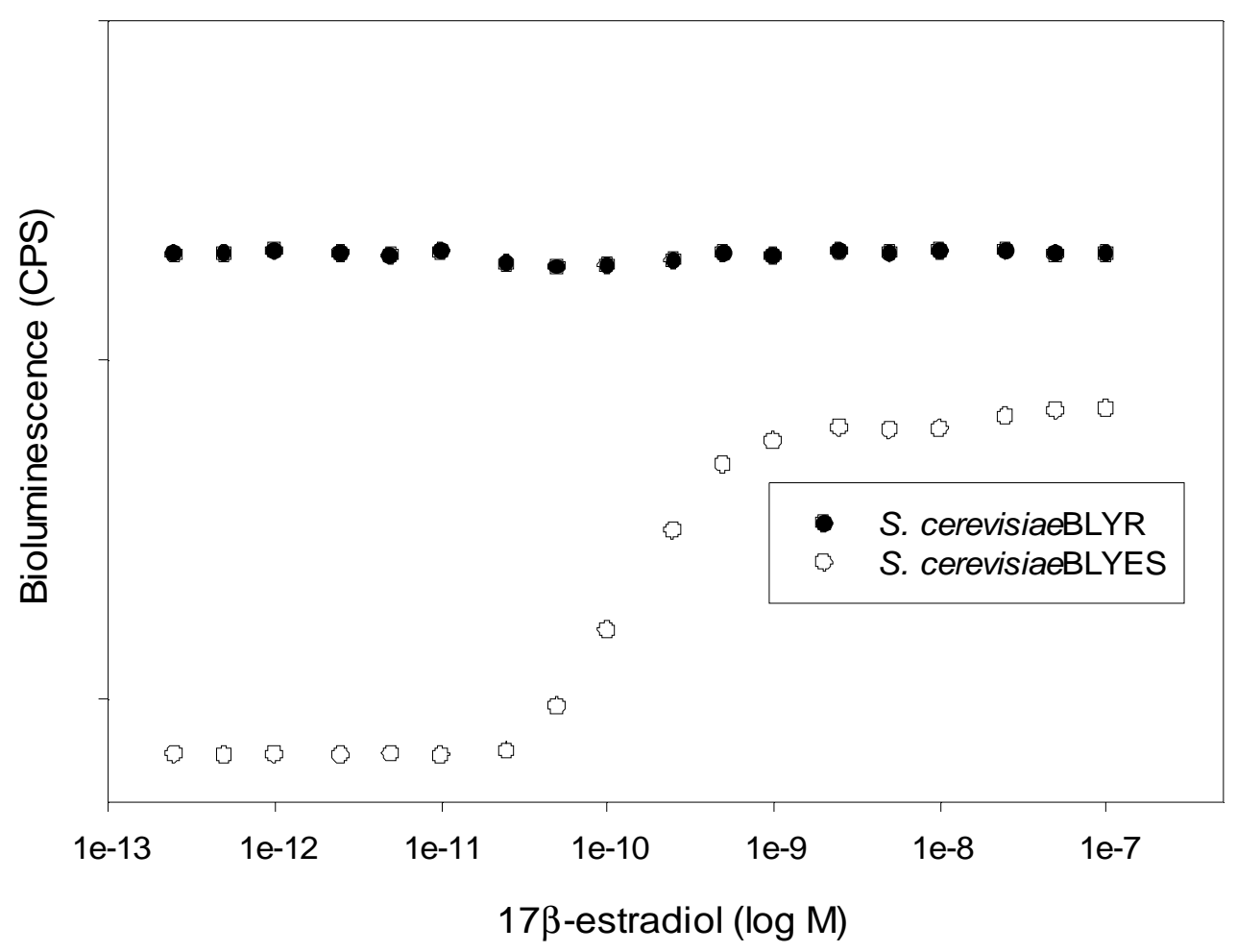

Figura 11 - Curva dose-resposta de 17ß-estradiol (intensidade de bioluminescência versus concentração molar) para a batelada de análise de amostras tratadas com cloro. 


\subsubsection{Amostras da ETA de São Carlos}

As Figuras 12 a 18 representam as curvas dose-resposta de atividade estrogênica do branco (água coletada na saída do filtro) e das amostras tratadas com cloro após contaminação por $17 \beta$-estradiol.

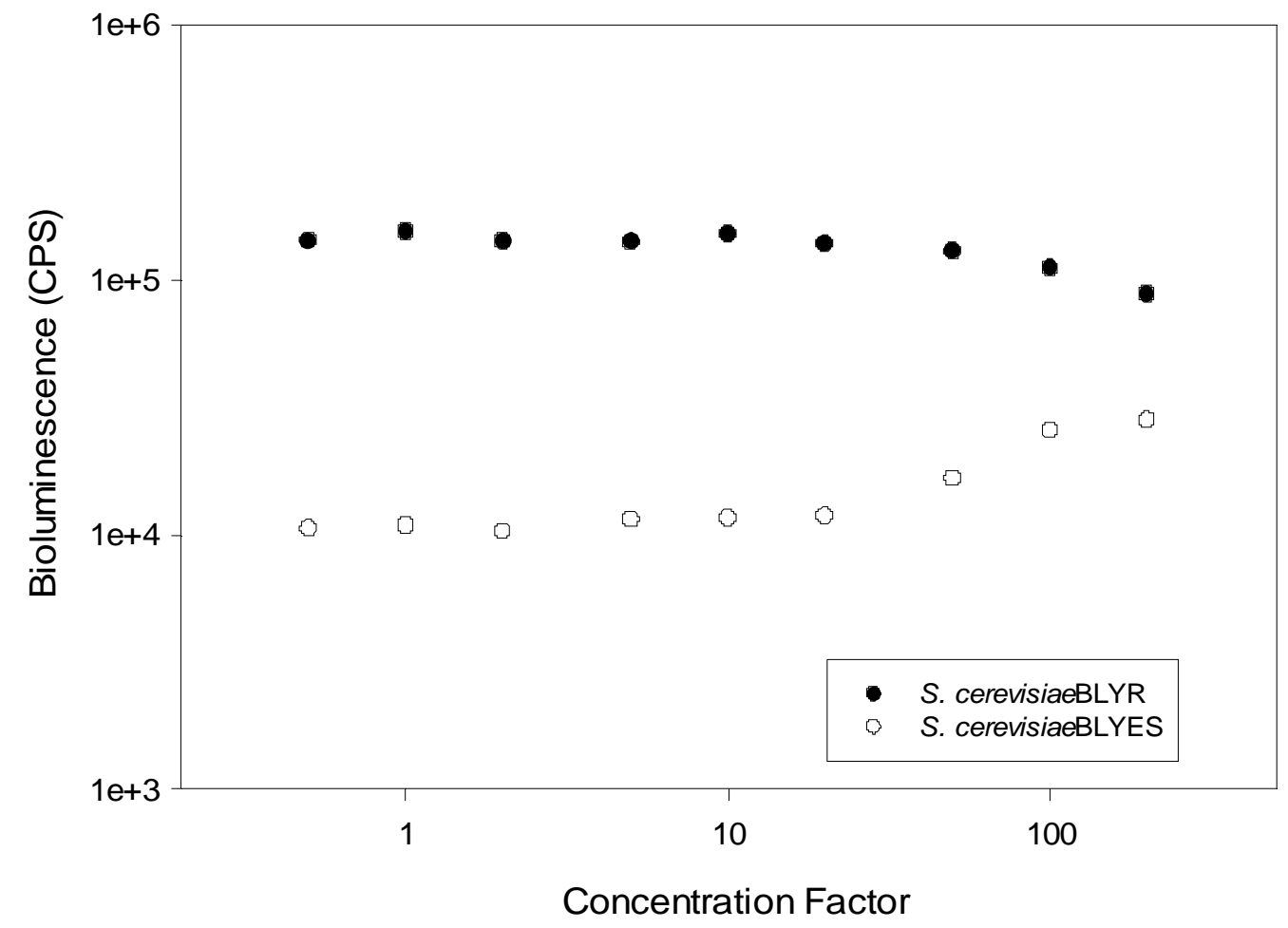

Figura 12 - Curva dose-resposta para o Branco da amostra $\mathrm{SC} \mathrm{Cl}_{2}$ (intensidade de bioluminescência versus fator de concentração) para análise de amostras de São Carlos tratadas cloro livre. 


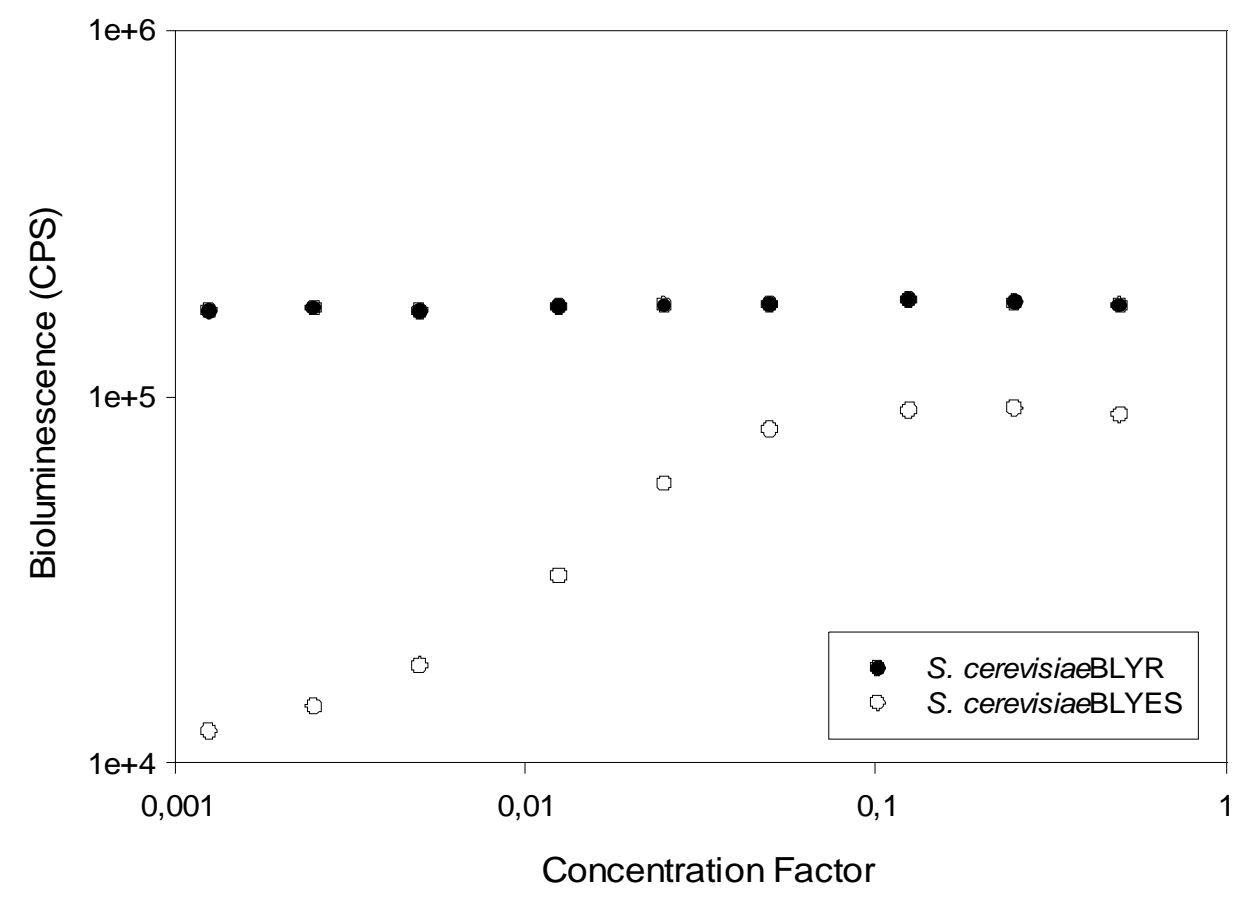

Figura 13 - Curva dose-resposta da amostra $\mathrm{SC} \mathrm{Cl}_{2} 1$ (intensidade de bioluminescência versus fator de concentração) - $1^{\text {a }}$ replicata da amostra de São Carlos com menores tempo de contato concentração de cloro livre.

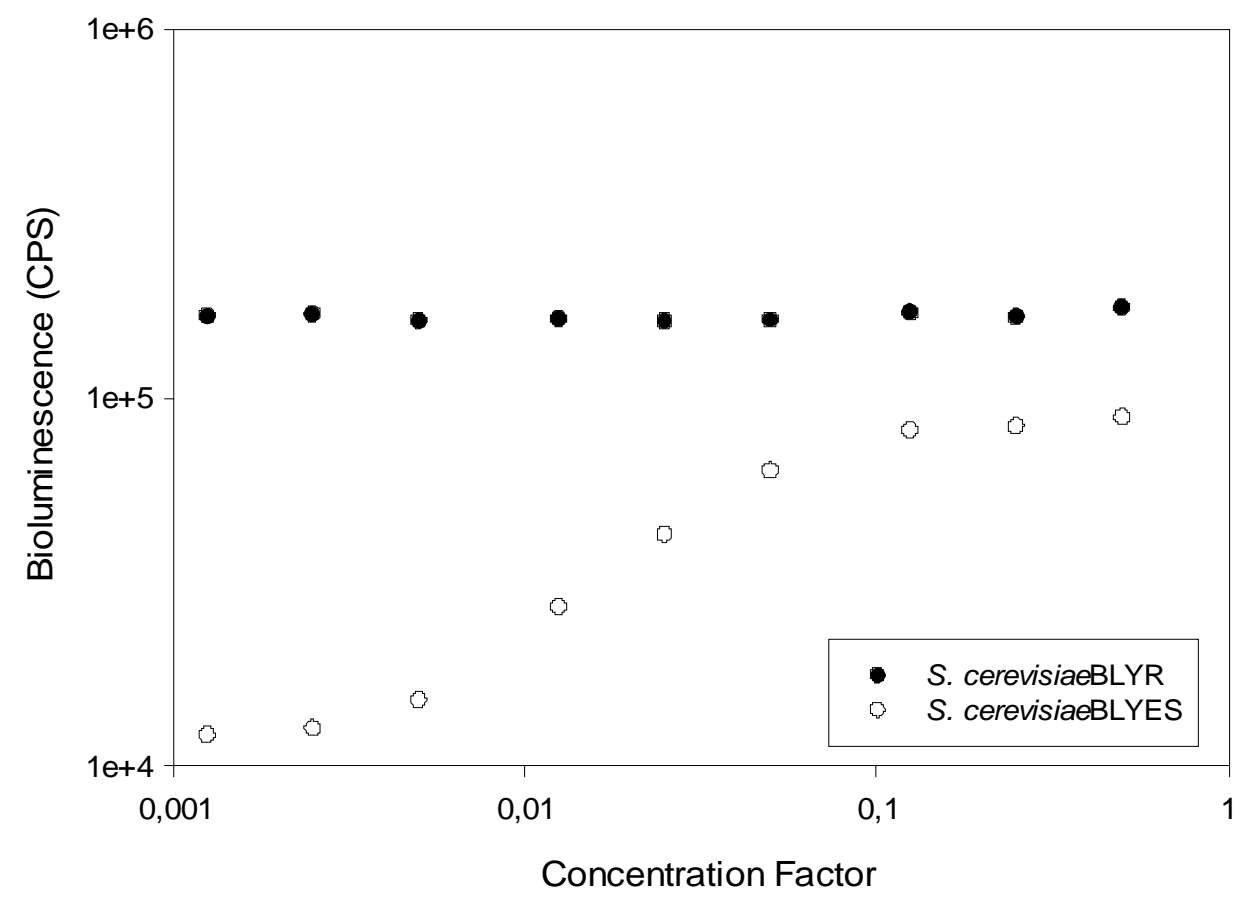

Figura 14 - Curva dose-resposta da amostra $\mathrm{SC} \mathrm{Cl}_{2} 2$ (intensidade de bioluminescência versus fator de concentração) $-2^{\mathrm{a}}$ replicata da amostra de São Carlos com menores tempo de contato concentração de cloro livre. 


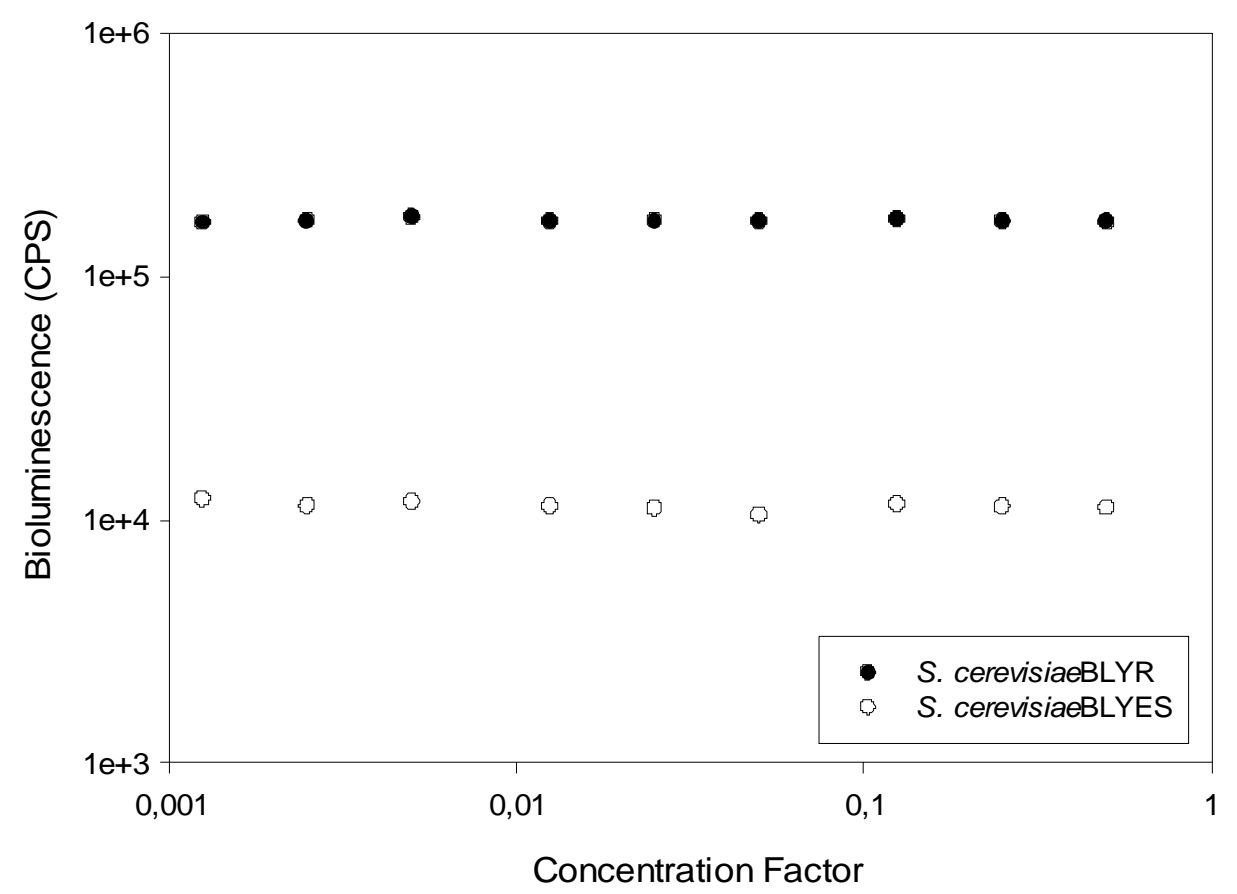

Figura 15 - Curva dose-resposta da amostra $\mathrm{SC} \mathrm{Cl}_{2} 3$ (intensidade de bioluminescência versus fator de concentração) $-3^{\text {a }}$ replicata da amostra de São Carlos com menores tempo de contato concentração de cloro livre.

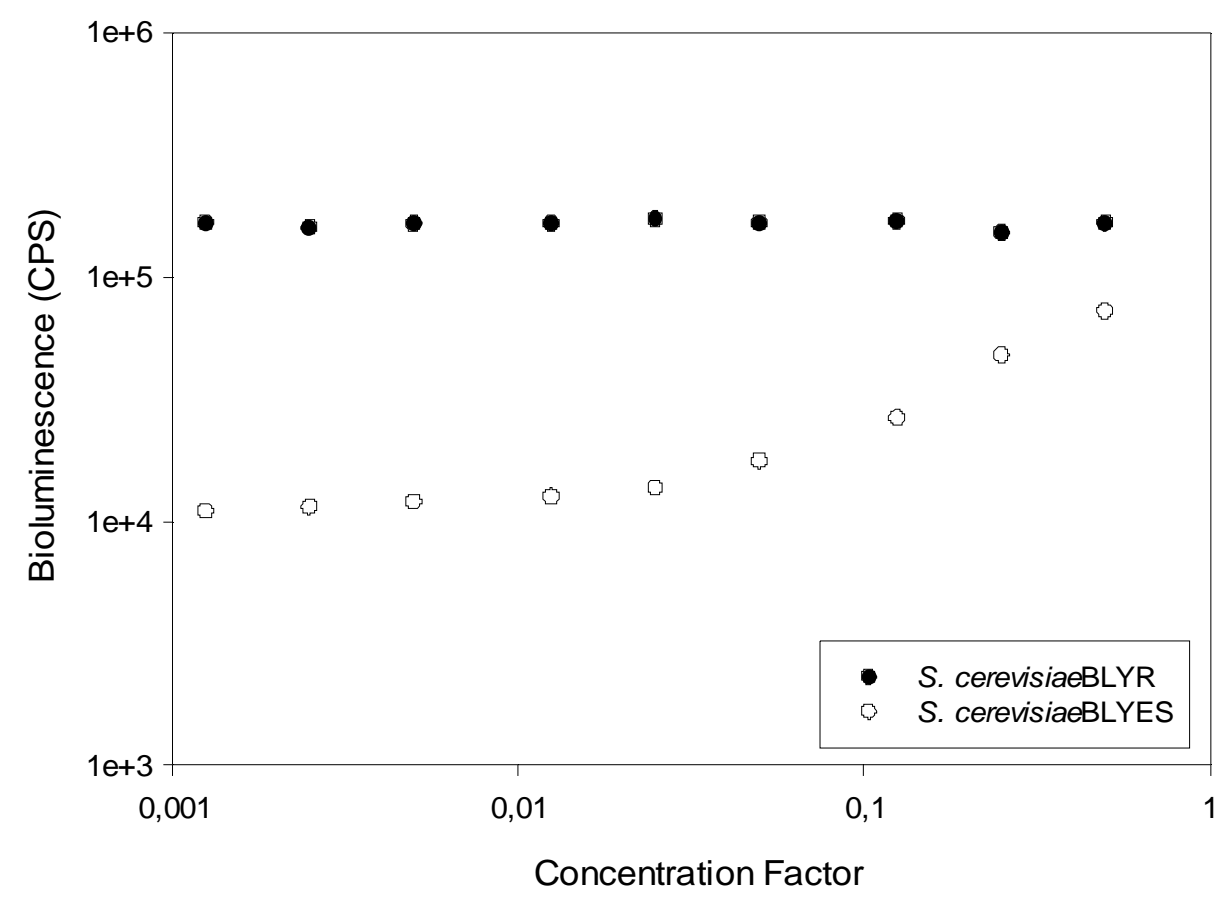

Figura 16 - Curva dose-resposta da amostra $\mathrm{SC} \mathrm{Cl}_{2} 4$ (intensidade de bioluminescência versus fator de concentração) $-1^{\text {a }}$ replicata da amostra de São Carlos com maiores tempo de contato concentração de cloro livre. 


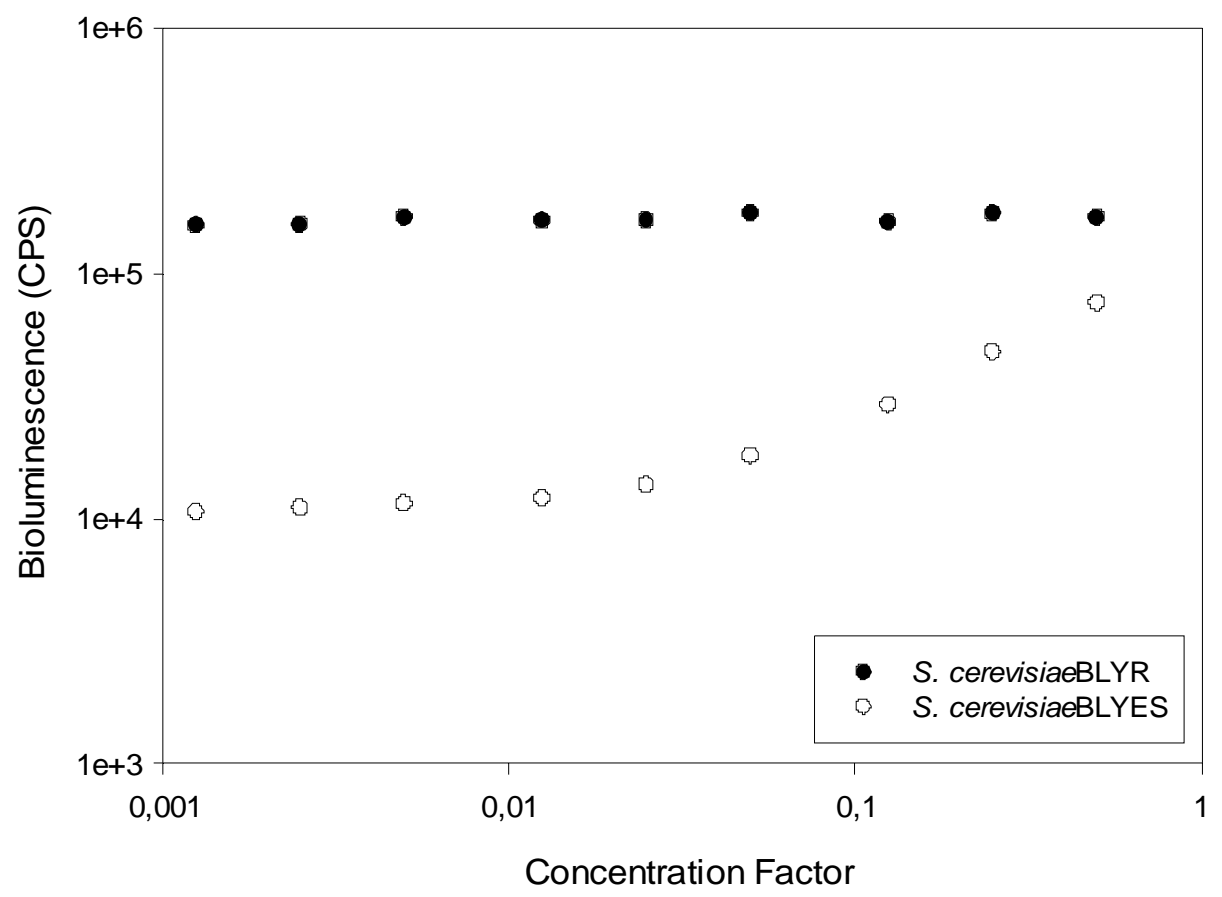

Figura 17 - Curva dose-resposta da amostra $\mathrm{SC} \mathrm{Cl}_{2} 5$ (intensidade de bioluminescência versus fator de concentração) $-2^{\mathrm{a}}$ replicata da amostra de São Carlos com maiores tempo de contato concentração de cloro livre.

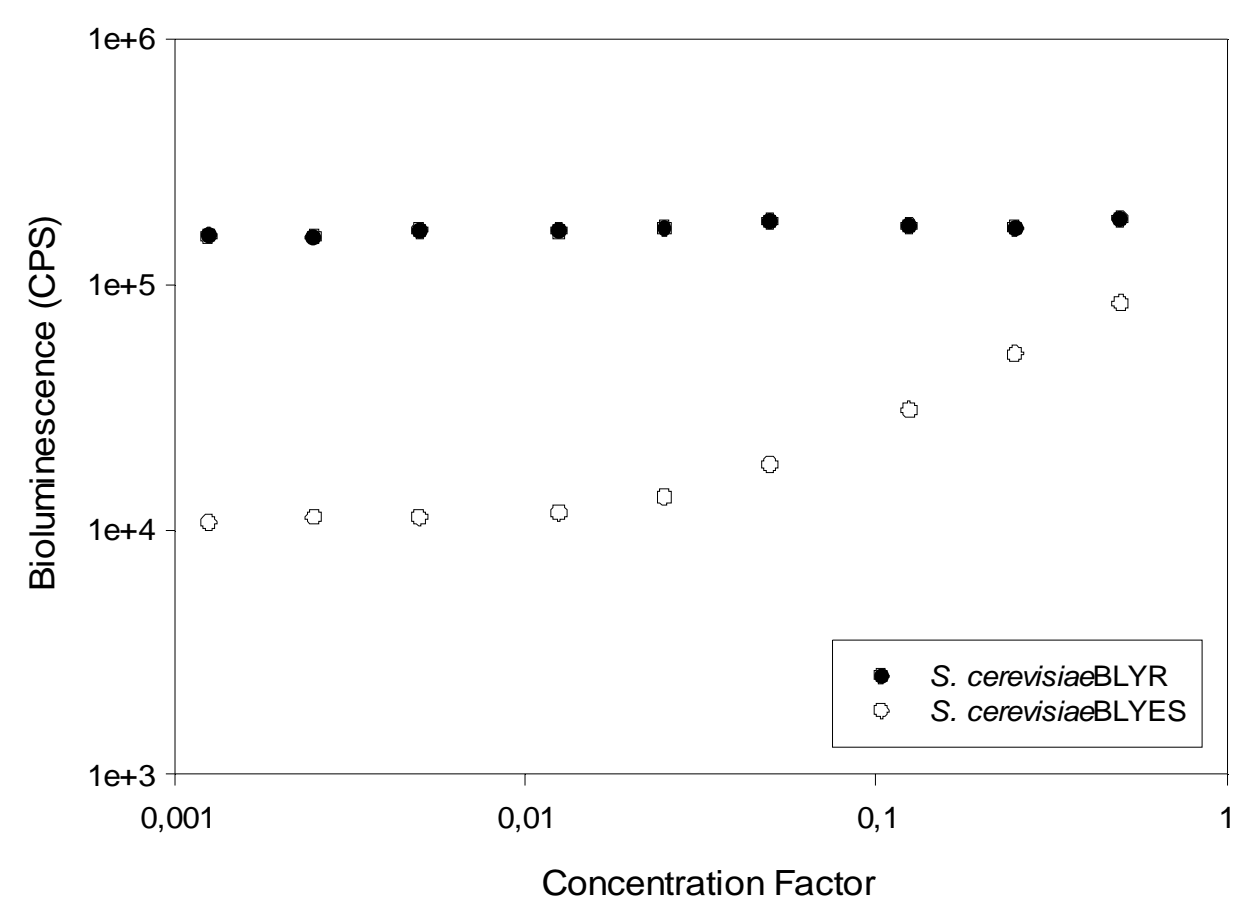

Figura 18 - Curva dose-resposta da amostra $\mathrm{SC} \mathrm{Cl}_{2} 4$ (intensidade de bioluminescência versus fator de concentração) $-3^{\text {a }}$ replicata da amostra de São Carlos com maiores tempo de contato concentração de cloro livre. 
Com base nas curvas de dose-resposta dos ensaios, por meio do programa SigmaPlot ${ }^{\circledR}$, foram obtidos os pontos máximos, mínimos e médios do padrão de E2, calculou-se o logaritmo do ponto médio, a equação da reta (bem como seus coeficientes angular e linear), seu coeficiente de correlação e os valores de $\mathrm{CE}_{50}$ e concentração molar (expressa em mol L ${ }^{-1}$ ) e em massa (expressa em ngE2equiv $L^{-1}$ ). As amostras 1, 2 e 3, bem como as 4, 5 e 6, representam as replicatas dos ensaios. A partir dos resultados obtidos, foi possível realizar um tratamento estatístico, com a expressão da média, desvio padrão e desvio padrão relativo da atividade estrogênica residual, representada na Tabela 5, e da remoção da atividade estrogênica, representada na Tabela 6.

Tabela 5 - Atividade estrogênica residual das amostras de água filtrada da ETA de São Carlos, contaminadas com 6.000 ngE2equiv $\mathrm{L}^{-1}$ e submetidas à cloração

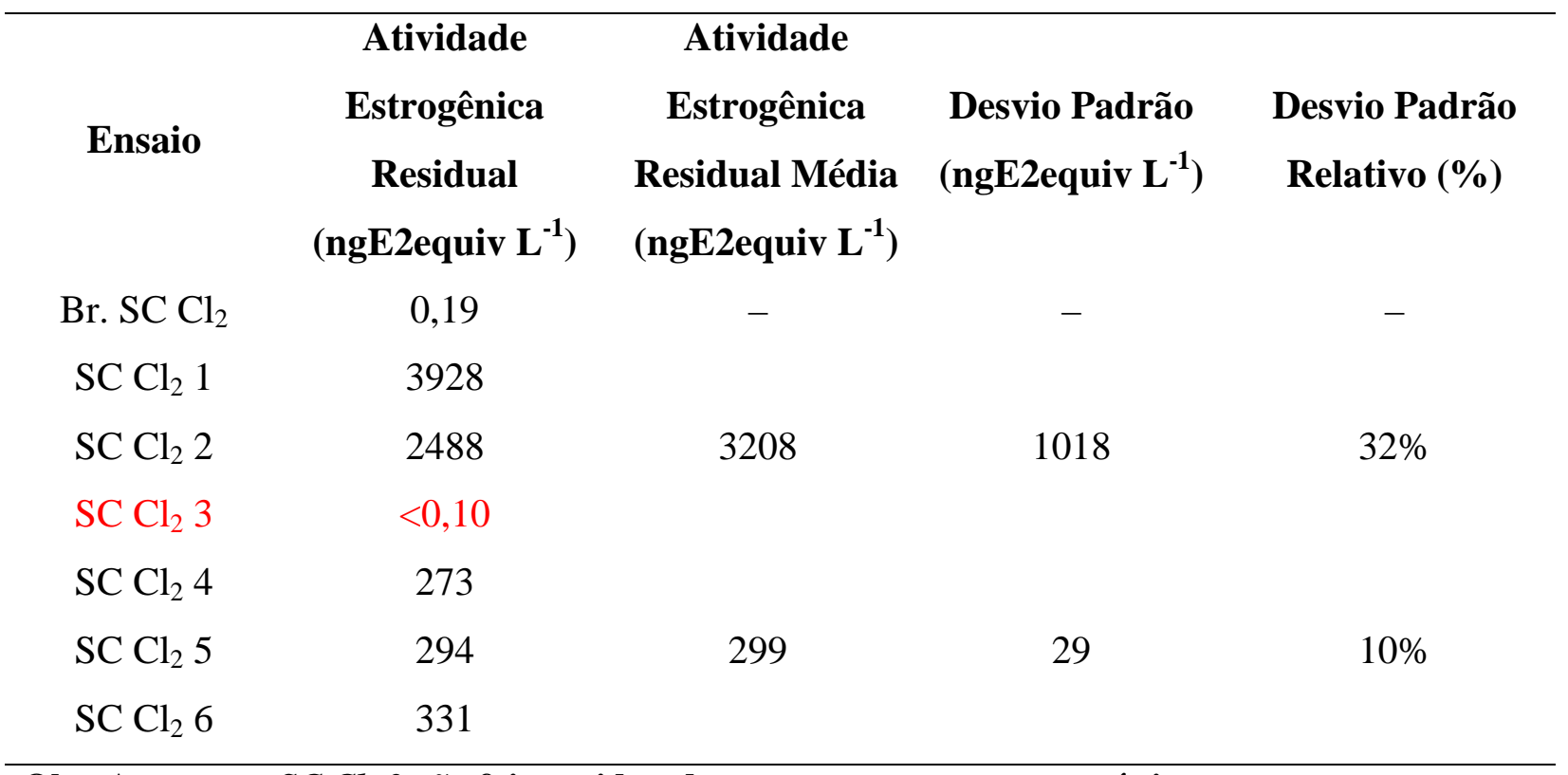

Obs: A amostra $\mathrm{SC} \mathrm{Cl}_{2} 3$ não foi considerada para os tratamentos estatísticos 
Tabela 6 - Remoção da Atividade estrogênica das amostras de água filtrada da ETA de São Carlos, contaminadas com 6.000 ngE2equiv $\mathrm{L}^{-1} \mathrm{e}$ submetidas à cloração

\begin{tabular}{ccccc}
\hline Ensaio & $\begin{array}{c}\text { Atividade } \\
\text { Estrogênica } \\
\text { Removida }\end{array}$ & $\begin{array}{c}\text { Remoção da } \\
\text { Atividade } \\
\text { (ngE2equiv L } \mathbf{- 1}^{-}\end{array}$ & $\begin{array}{c}\text { Remoção Média } \\
\text { da Atrogênica (\%) }\end{array}$ & $\begin{array}{c}\text { Estrogênica (\%) } \\
\text { Desvio Padrão } \\
\text { Relativo (\%) }\end{array}$ \\
$\mathrm{SC} \mathrm{Cl}_{2} 1$ & 2072 & $34,5 \%$ & & \\
$\mathrm{SC} \mathrm{Cl}_{2} 2$ & 3512 & $58,5 \%$ & $46,5 \%$ & $17 \%$ \\
$\mathrm{SC} \mathrm{Cl}_{2} 3$ & $<0,10$ & $100 \%$ & & \\
$\mathrm{SC} \mathrm{Cl}_{2} 4$ & 5727 & $95,5 \%$ & & $0,5 \%$ \\
$\mathrm{SC} \mathrm{Cl}_{2} 5$ & 5706 & $95,1 \%$ & $95,0 \%$ & \\
$\mathrm{SC} \mathrm{Cl}_{2} 6$ & 5669 & $94,5 \%$ & & \\
\hline
\end{tabular}

Obs: A amostra $\mathrm{SC} \mathrm{Cl}_{2} 3$ não foi considerada para os tratamentos estatísticos

Dos resultados, verifica-se que as amostras tratadas com cloro total inicial de $1,38 \mathrm{mg} \mathrm{L}^{-1}$ por $30 \mathrm{~min}$ apresentaram, em média, eficiência de remoção de estrogenicidade 2,05 vezes maior em relação às tratadas com cloro total inicial de $0,39 \mathrm{mg} \mathrm{L}^{-1}$ por $10 \mathrm{~min}$. Constatou-se também que as replicatas com maiores concentrações de cloro por um intervalo de tempo maior ( $\mathrm{SC}_{2} 4,5$ e 6) apresentaram uma repetibilidade maior em relação às replicatas com menores dosagens de cloro em menores intervalos de tempo ( $\mathrm{SC} \mathrm{Cl}_{2} 1$ e 2$)$. $\mathrm{O}$ fato pode ser explicado por ter ocorrido um erro aleatório nestes ensaios, o que explicaria também a perda da amostra replicada $\mathrm{SC} \mathrm{Cl}_{2} 3$.

Quantificou-se atividade estrogênica no branco (saída do filtro da ETA de São Carlos) em 0,19 ngE2equiv $\mathrm{L}^{-1}$, valor bem próximo do limite de quantificação do método $(0,10$ ngE2equiv $\mathrm{L}^{-1}$ ). Pode ter ocorrido uma contaminação cruzada entre esse branco e uma das amostras contaminadas com o hormônio estudado. Esse valor encontrado, caso presente na amostra, não é preocupante, considerando que a água da saída do filtro passaria ainda por processo de cloração, no entanto, trata-se de um indicativo de contaminação antrópica no manancial que abastece metade da cidade de São Carlos. Frisa-se que se trata de uma análise única, sem replicatas, e, portanto, sem segurança de sua presença. 
Verificou-se, também, uma significativa demanda de agente oxidante pela matriz da amostra, o que indica a presença de agentes redutores

Todavia, a cinética de remoção da atividade estrogênica nas replicatas para aplicação de $1,38 \mathrm{mg} \mathrm{L}^{-1}$ por $30 \mathrm{~min}$, com residual de $0,60 \mathrm{mg} \mathrm{L}^{-1}$ pode ser considerada baixa, em vista de uma remoção média de 95,0\% da atividade estrogênica de uma amostra com elevada concentração inicial de $17 \beta$-estradiol (de $6.000 \mathrm{ng} \mathrm{L}^{-1}$ ). Elucidou-se que a taxa de remoção da atividade estrogênica na amostra pode ser reduzida para menores concentrações do hormônio objeto do presente estudo.

\subsubsection{Amostras das ETAs 3 e 4 de Campinas}

As Figuras 19 a 25 representam as curvas dose-resposta de atividade estrogênica do branco (água coletada na saída do filtro) e das amostras tratadas com cloro após contaminação por $17 \beta$-estradiol.

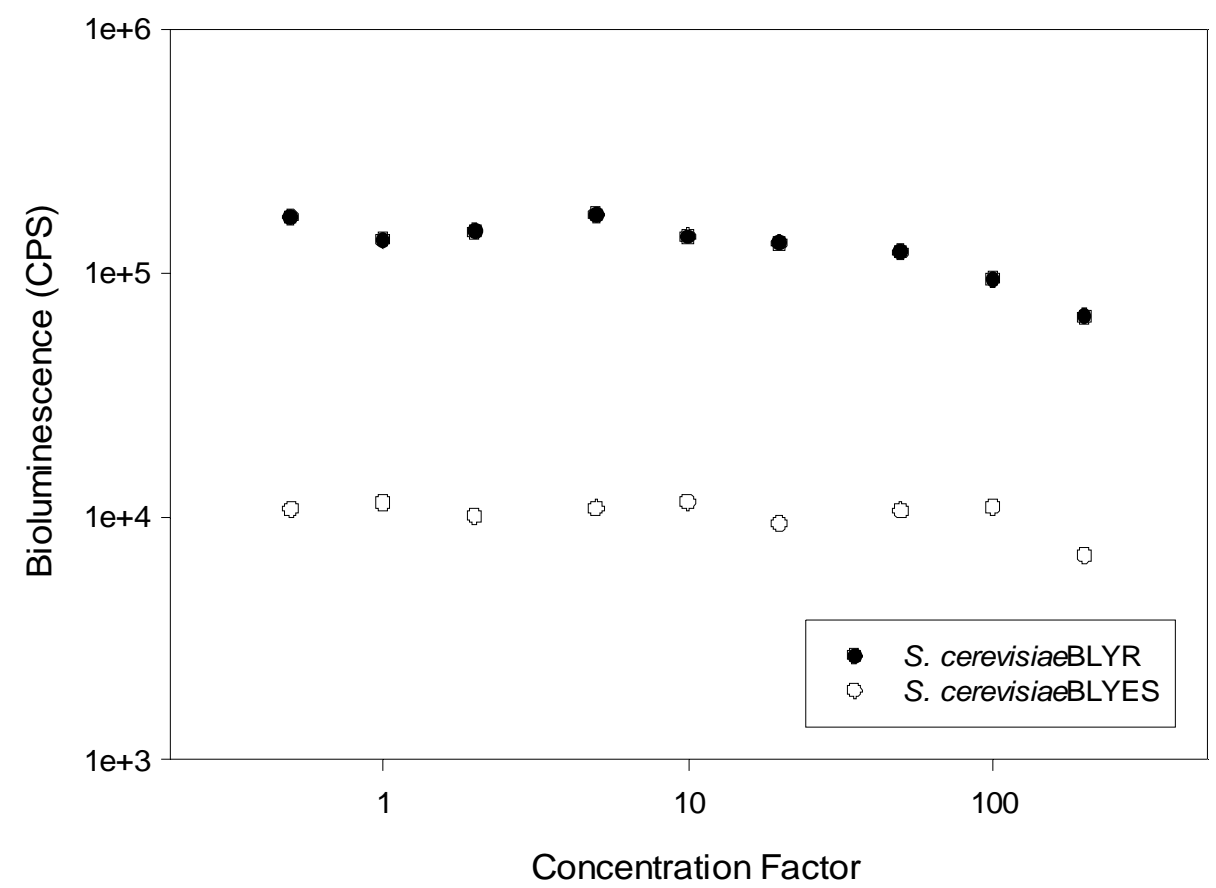

Figura 19 - Curva dose-resposta para o Branco da amostra $\mathrm{CPS} \mathrm{Cl}_{2}$ (intensidade de bioluminescência versus fator de concentração) para análise de amostras de Campinas tratadas cloro livre. 


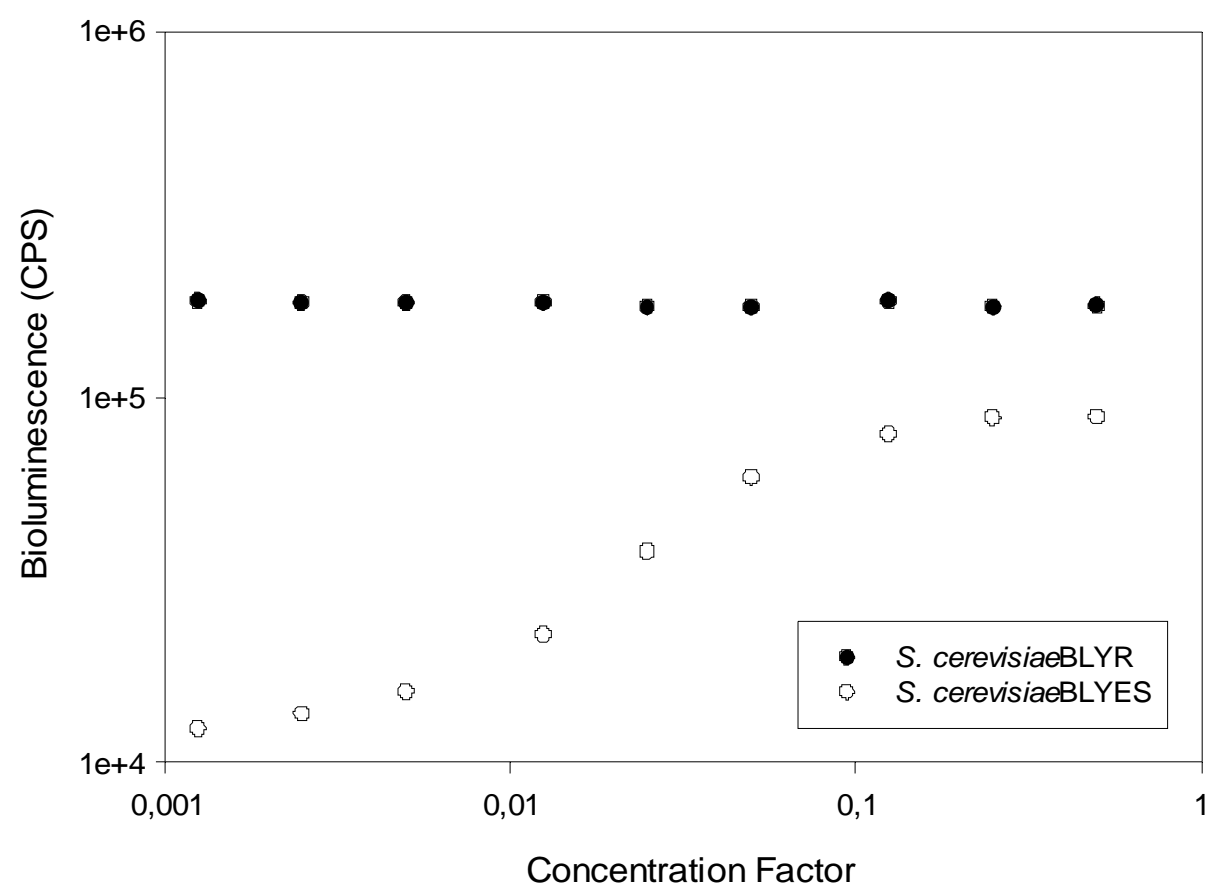

Figura 20 - Curva dose-resposta da amostra $\mathrm{CPS} \mathrm{Cl}_{2} 1$ (intensidade de bioluminescência versus fator de concentração) - $1^{\text {a }}$ replicata da amostra de Campinas com menores tempo de contato concentração de cloro livre.

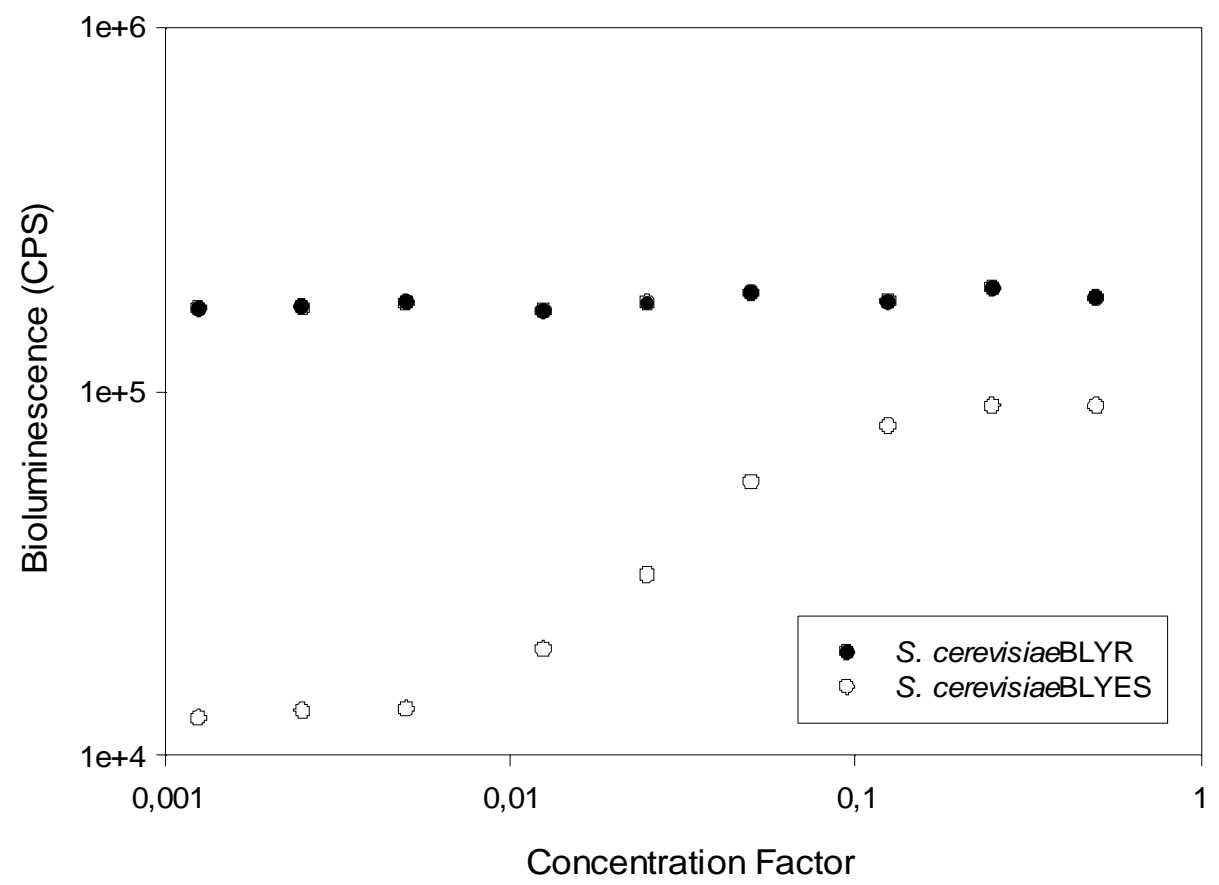

Figura 21 - Curva dose-resposta da amostra $\mathrm{CPS} \mathrm{Cl}_{2} 2$ (intensidade de bioluminescência versus fator de concentração) $-2^{\mathrm{a}}$ replicata da amostra de Campinas com menores tempo de contato concentração de cloro livre. 


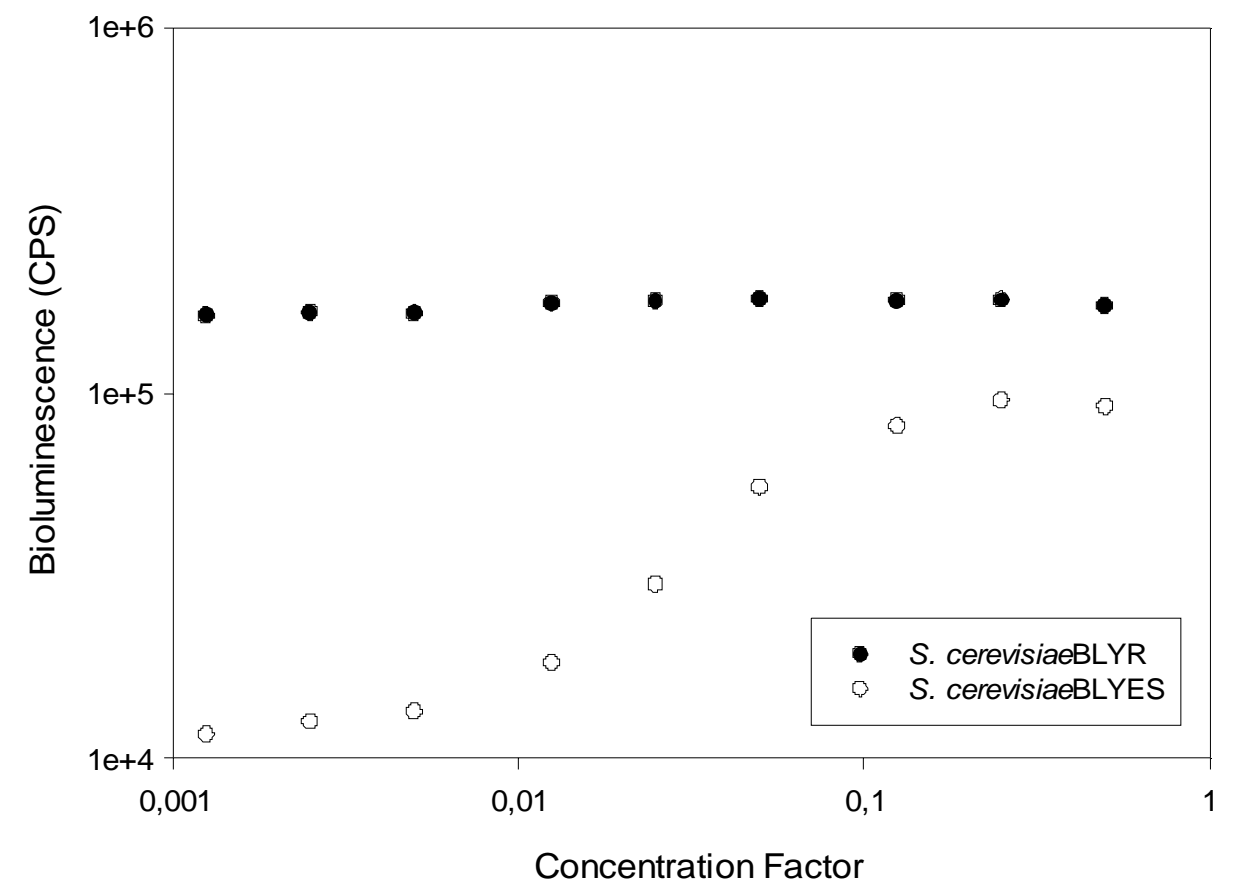

Figura 22 - Curva dose-resposta da amostra $\mathrm{CPS} \mathrm{Cl}_{2} 3$ (intensidade de bioluminescência versus fator de concentração) $-3^{\text {a }}$ replicata da amostra de Campinas com menores tempo de contato concentração de cloro livre.

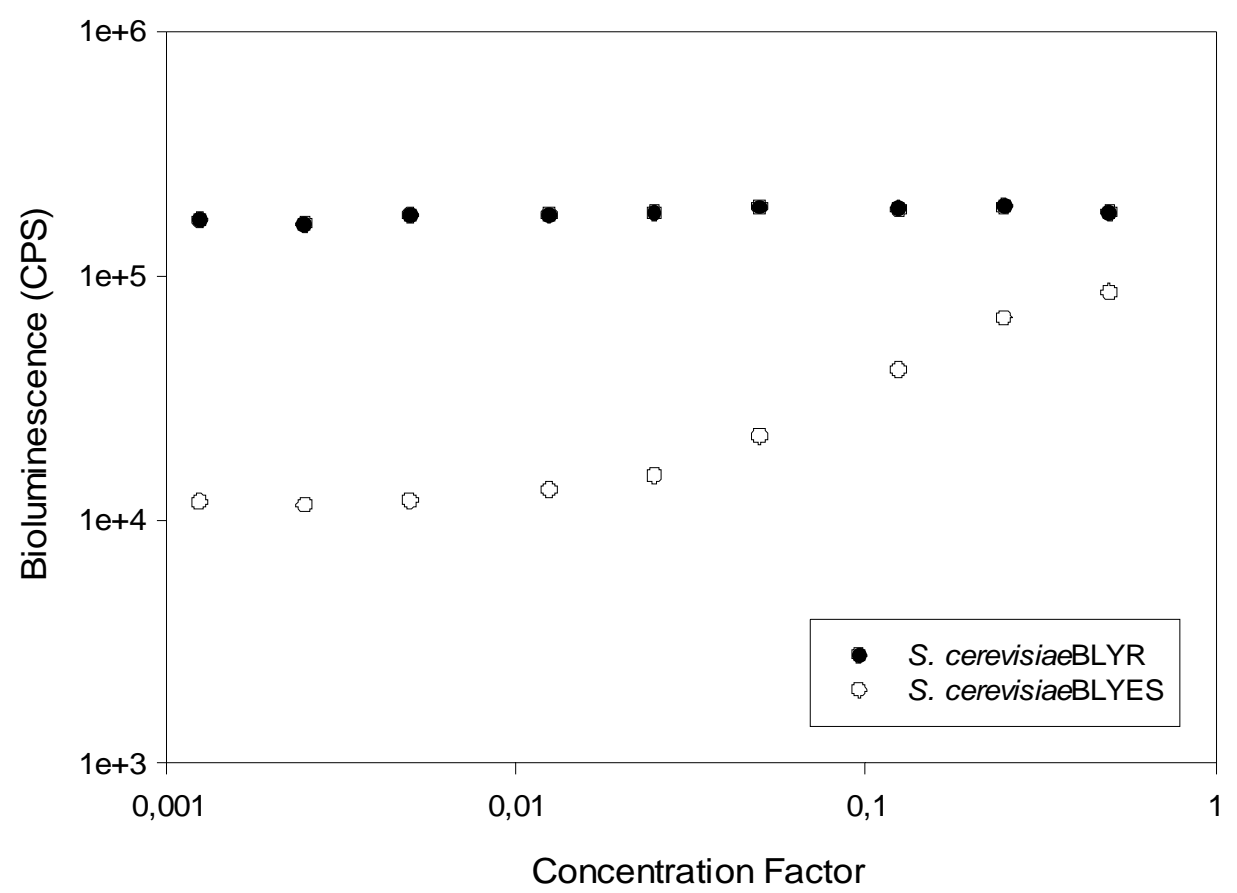

Figura 23 - Curva dose-resposta da amostra $\mathrm{CPS} \mathrm{Cl}_{2} 4$ (intensidade de bioluminescência versus fator de concentração) $-1^{\mathrm{a}}$ replicata da amostra de Campinas com maiores tempo de contato concentração de cloro livre. 


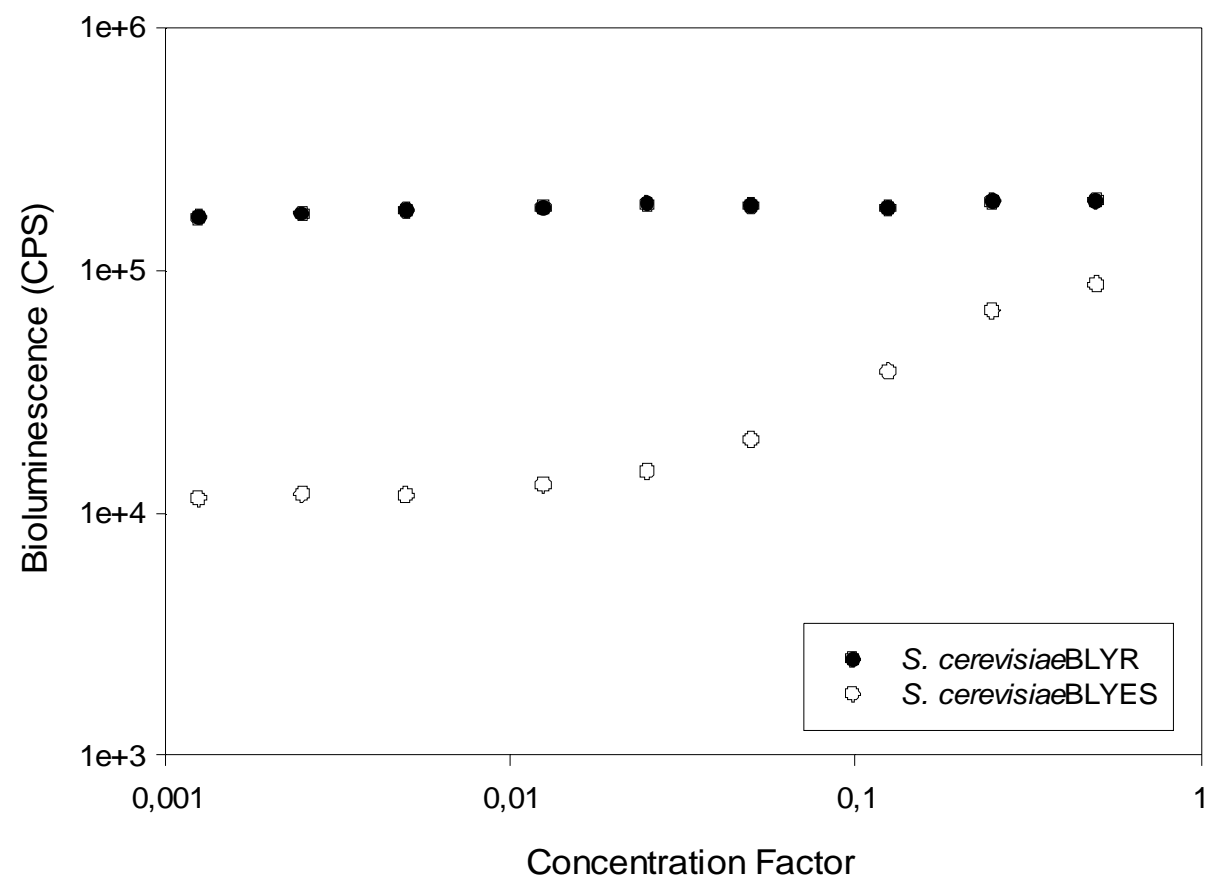

Figura 24 - Curva dose-resposta da amostra $\mathrm{CPS} \mathrm{Cl}_{2} 5$ (intensidade de bioluminescência versus fator de concentração) $-2^{\text {a }}$ replicata da amostra de Campinas com maiores tempo de contato concentração de cloro livre.

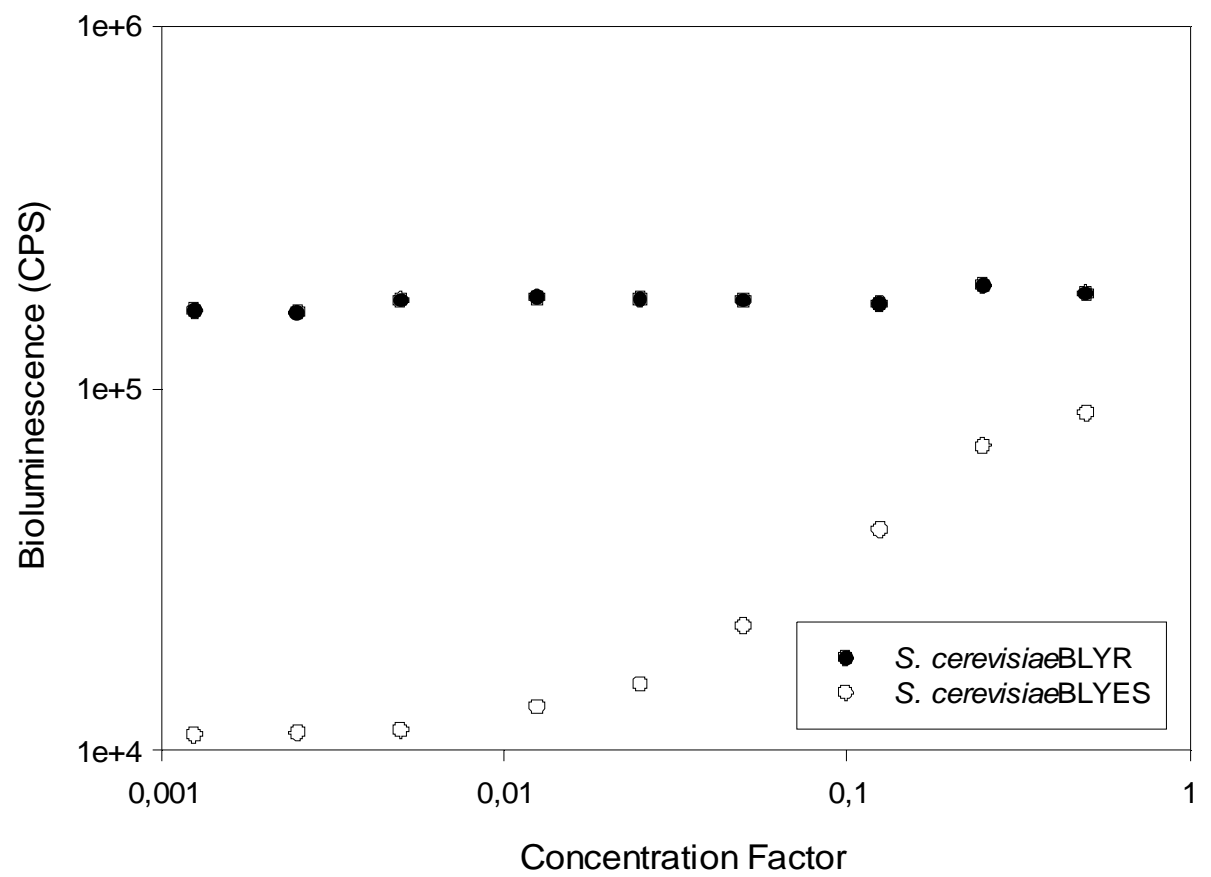

Figura 25 - Curva dose-resposta da amostra $\mathrm{CPS} \mathrm{Cl}_{2} 6$ (intensidade de bioluminescência versus fator de concentração) $-3^{a}$ replicata da amostra de Campinas com maiores tempo de contato concentração de cloro livre. 
Com base nas curvas de dose-resposta dos ensaios, por meio do programa SigmaPlot ${ }^{\circledR}$, foram obtidos os pontos máximos, mínimos e médios do padrão de E2, calculou-se o logaritmo do ponto médio, a equação da reta (bem como seus coeficientes angular e linear), seu coeficiente de correlação e os valores de $\mathrm{CE}_{50}$ e concentração molar (expressa em mol L'-1) e em massa (expressa em ngE2equiv $L^{-1}$ ). As amostras 1, 2 e 3, bem como as 4, 5 e 6, representam as replicatas dos ensaios. A partir dos resultados obtidos, foi possível realizar um tratamento estatístico, com a expressão da média, desvio padrão e desvio padrão relativo da atividade estrogênica residual, representada na Tabela 7 , e da remoção da atividade estrogênica, representada na Tabela 8.

Tabela 7 - Atividade estrogênica residual das amostras de água filtrada das ETAs 3 e 4 de Campinas, contaminadas com 6.000 ngE2equiv $\mathrm{L}^{-1} \mathrm{e}$ submetidas à cloração

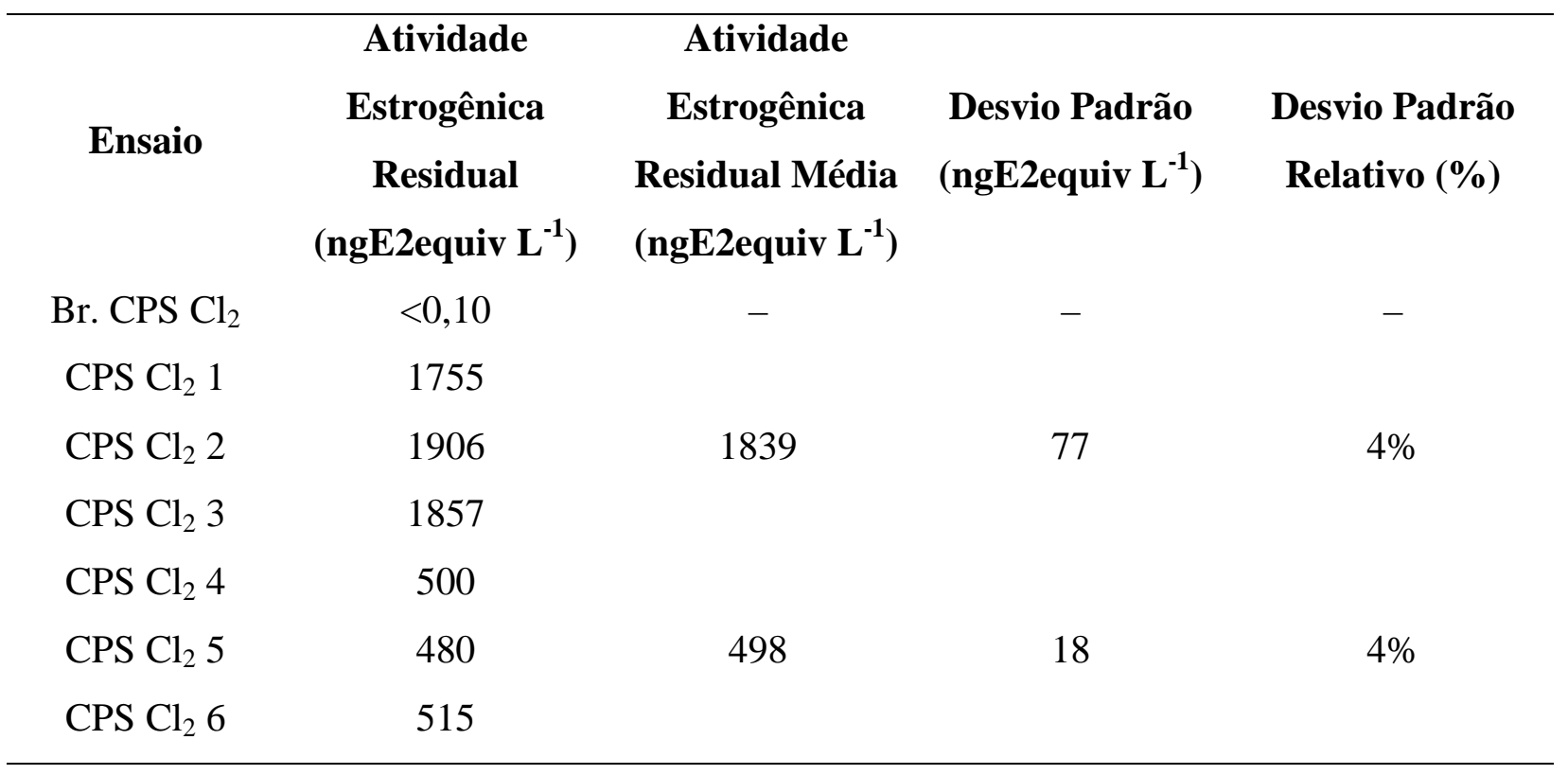


Tabela 8 - Remoção da Atividade estrogênica das amostras de água filtrada da ETAs 3 e 4 de Campinas, contaminadas com 6.000 ngE2equiv $\mathrm{L}^{-1} \mathrm{e}$ submetidas à cloração

\begin{tabular}{|c|c|c|c|c|}
\hline Ensaio & 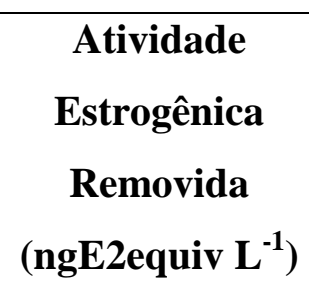 & $\begin{array}{c}\text { Remoção da } \\
\text { Atividade } \\
\text { Estrogênica (\%) }\end{array}$ & $\begin{array}{c}\text { Remoção Média } \\
\text { da Atividade } \\
\text { Estrogênica }(\%)\end{array}$ & $\begin{array}{l}\text { Desvio Padrão } \\
\text { Relativo (\%) }\end{array}$ \\
\hline $\mathrm{CPS} \mathrm{Cl}_{2} 1$ & 4245 & $70,8 \%$ & & \\
\hline $\mathrm{CPS} \mathrm{Cl}_{2} 2$ & 4094 & $68,2 \%$ & $69,3 \%$ & $1,3 \%$ \\
\hline $\mathrm{CPS} \mathrm{Cl}_{2} 3$ & 4143 & $69,1 \%$ & & \\
\hline $\mathrm{CPS} \mathrm{Cl}_{2} 4$ & 5500 & $91,7 \%$ & & \\
\hline $\mathrm{CPS} \mathrm{Cl}_{2} 5$ & 5520 & $92,0 \%$ & $91,7 \%$ & $0,3 \%$ \\
\hline $\mathrm{CPS} \mathrm{Cl}_{2} 6$ & 5485 & $91,4 \%$ & & \\
\hline
\end{tabular}

Destaca-se que as ETAs 3 e 4 da SANASA de Campinas - SP, diferentemente da ETA do SAAE de São Carlos - SP, possui um pré-tratamento no sistema, que é a pré-cloração da água. Por conta disso, a água chega aos filtros da estação de tratamento com residual de cloro total. Optou-se por não remover esse agente oxidante da amostra coletada para evitar uma adição excessiva de agente redutor e por ser desnecessário, pois observou-se que a dosagem de cloro na amostra no momento dos ensaios em laboratório se aproximava de $0,5 \mathrm{mg} \mathrm{\textrm {L } ^ { - 1 }}$ (condição de menor dosagem neste trabalho)

Dos resultados, verifica-se que as amostras tratadas com cloro total inicial de $1,18 \mathrm{mg}$ $\mathrm{L}^{-1}$ por 30 min apresentaram, em média, eficiência de remoção de estrogenicidade 1,32 vezes maior em relação às tratadas com cloro total inicial de $0,76 \mathrm{mg} \mathrm{L}^{-1}$ por $10 \mathrm{~min}$. Constatou-se também que as replicatas com maiores concentrações de cloro por um intervalo de tempo maior $\left(\mathrm{CPS} \mathrm{Cl}_{2} 4,5\right.$ e 6$)$ apresentaram uma repetibilidade muito semelhante às replicatas com menores dosagens de cloro em menores intervalos de tempo ( $\mathrm{CPS}^{\mathrm{Cl}} \mathrm{l}_{2} 1,2$ e 3 ).

Depreende-se dos resultados obtidos que a demanda por agente oxidante da matriz de Campinas é significativamente menor em relação à de São Carlos. Por esse fato, observou-se, também, menores desvios padrões da atividade estrogênica residual. 
Todavia, a cinética de remoção da atividade estrogênica nas replicatas para aplicação de $1,18 \mathrm{mg} \mathrm{L}^{-1}$ por $30 \mathrm{~min}$, com residual de $1,12 \mathrm{mg} \mathrm{L}^{-1}$ pode ser considerada baixa, em vista de uma remoção média de $91,7 \%$ da atividade estrogênica de uma amostra com elevada concentração inicial de $17 \beta$-estradiol (de $6.000 \mathrm{ng} \mathrm{L}^{-1}$ ).

\subsection{Amostras contaminadas com 17ß-estradiol e tratadas com ozônio}

Após a etapa de concentração das amostras nos cartuchos C-18, estes foram armazenados sob refrigeração até sua análise no laboratório do Setor de Análises Toxicológicas da CETESB. O transporte dos cartuchos entre as cidades de São Carlos - SP e São Paulo - SP também foi conduzido sob refrigeração.

As variáveis que influenciam o resultado da atividade estrogênica nos ensaios de oxidação com ozônio consistem em, basicamente: concentração de 17ß-estradiol, concentração aplicada de ozônio, ozônio consumido e tempo de contato. Outros fatores, como a demanda da matriz pelo agente oxidante, podem ser relevantes.

As Figuras de curva dose-resposta de 17ß-estradiol e das amostras (intensidade de bioluminescência versus concentração molar) foram disponibilizada pela CETESB, obtida para o ensaio BLYES (atividade estrogênica) e BLYR (toxicidade).

A curva padrão de $17 \beta$-estradiol resultante do ensaio no laboratório do Setor de Análises Toxicológicas da CETESB (Figura 26) na batelada para determinação da atividade estrogênica das amostras tratadas com ozônio, assim como observado na Figura 11, apresenta o formato sigmoidal, o que atende ao esperado. Obteve-se uma ampla faixa de luminescência, o que era esperado e está de acordo com os resultados obtidos por Jardim (2012), Eldridge et al., (2011), Raimundo (2011) e Sanseverino et al., (2009). 


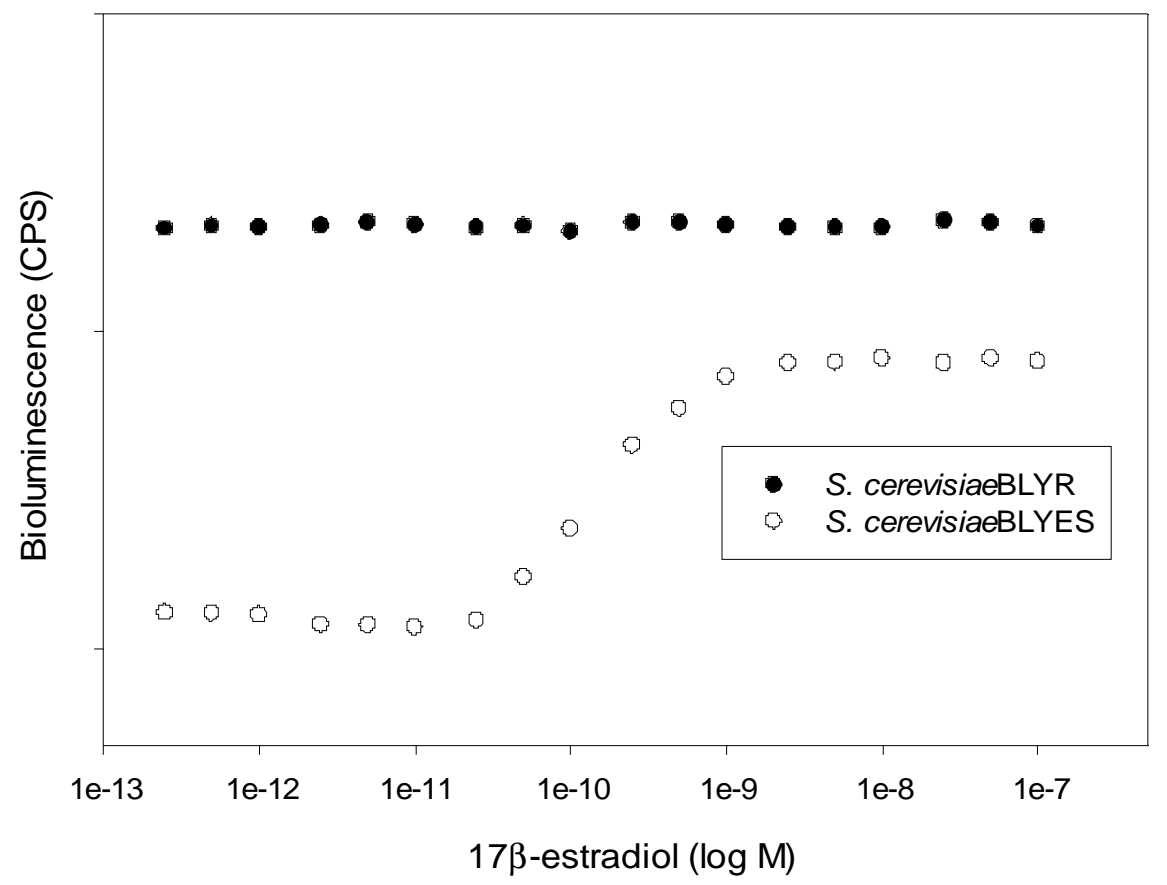

Figura 26 - Curva dose-resposta de 17ß-estradiol (intensidade de bioluminescência versus concentração molar) para a batelada de análise de amostras tratadas com ozônio.

\subsubsection{Amostras da ETA de São Carlos}

As Figuras 27 a 31 representam as curvas dose-resposta de atividade estrogênica do branco (água coletada na saída do filtro) e das amostras tratadas com ozônio após contaminação por $17 \beta$-estradiol. 


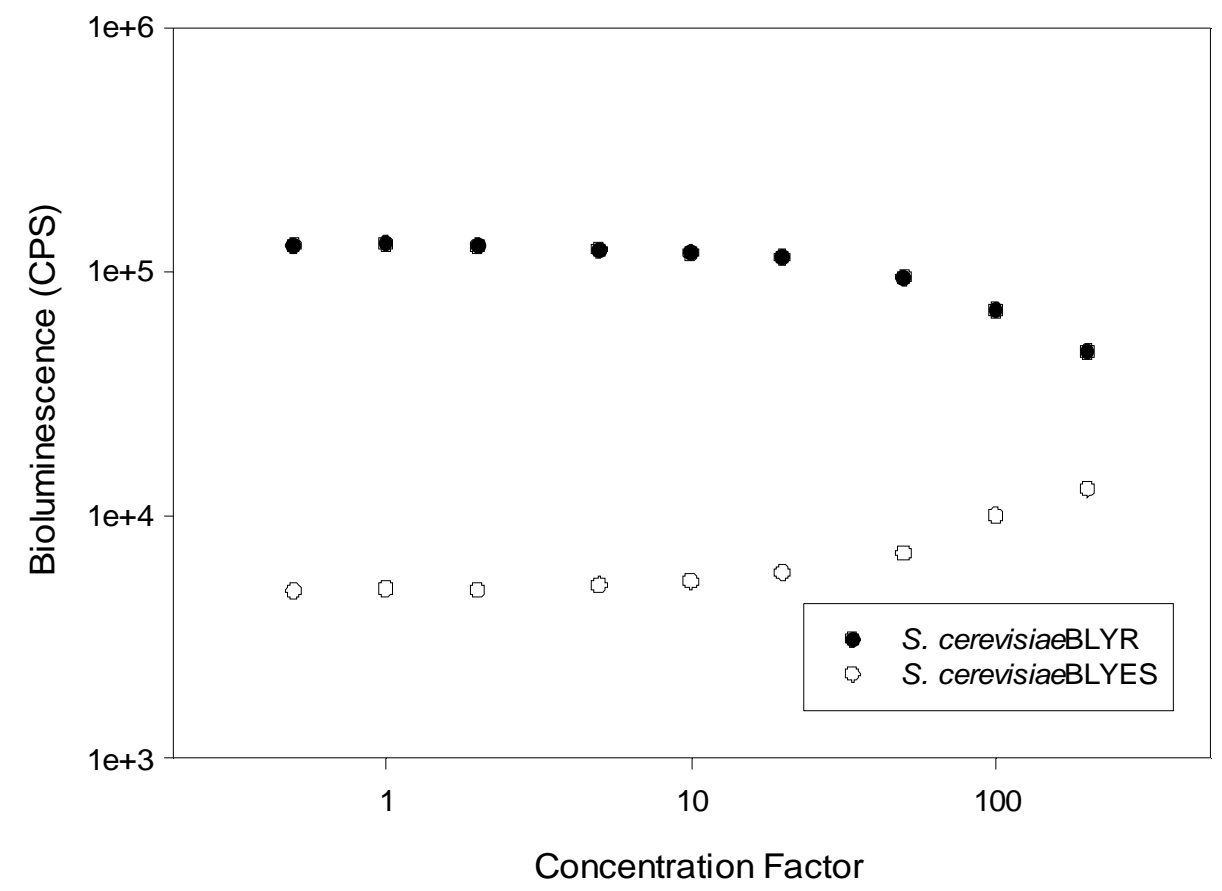

Figura 27 - Curva dose-resposta para o Branco da amostra $\mathrm{SC} \mathrm{O}_{3}$ (intensidade de bioluminescência versus fator de concentração) para análise de amostras de São Carlos tratadas com ozônio. 


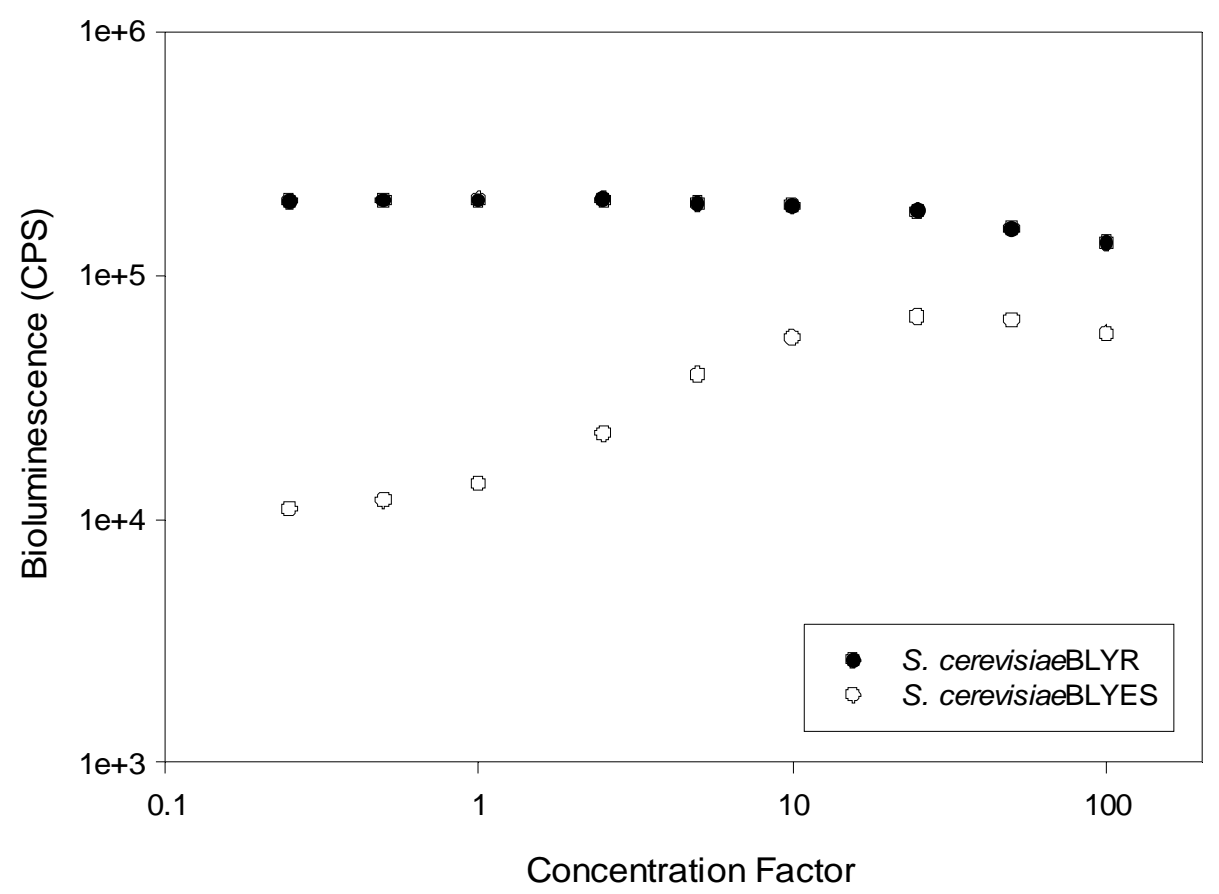

Figura 28 - Curva dose-resposta da amostra $\mathrm{SC} \mathrm{O}_{3} 1$ (intensidade de bioluminescência versus fator de concentração) - $1^{\text {a }}$ replicata da amostra de São Carlos com menores tempo de contato concentração de ozônio.

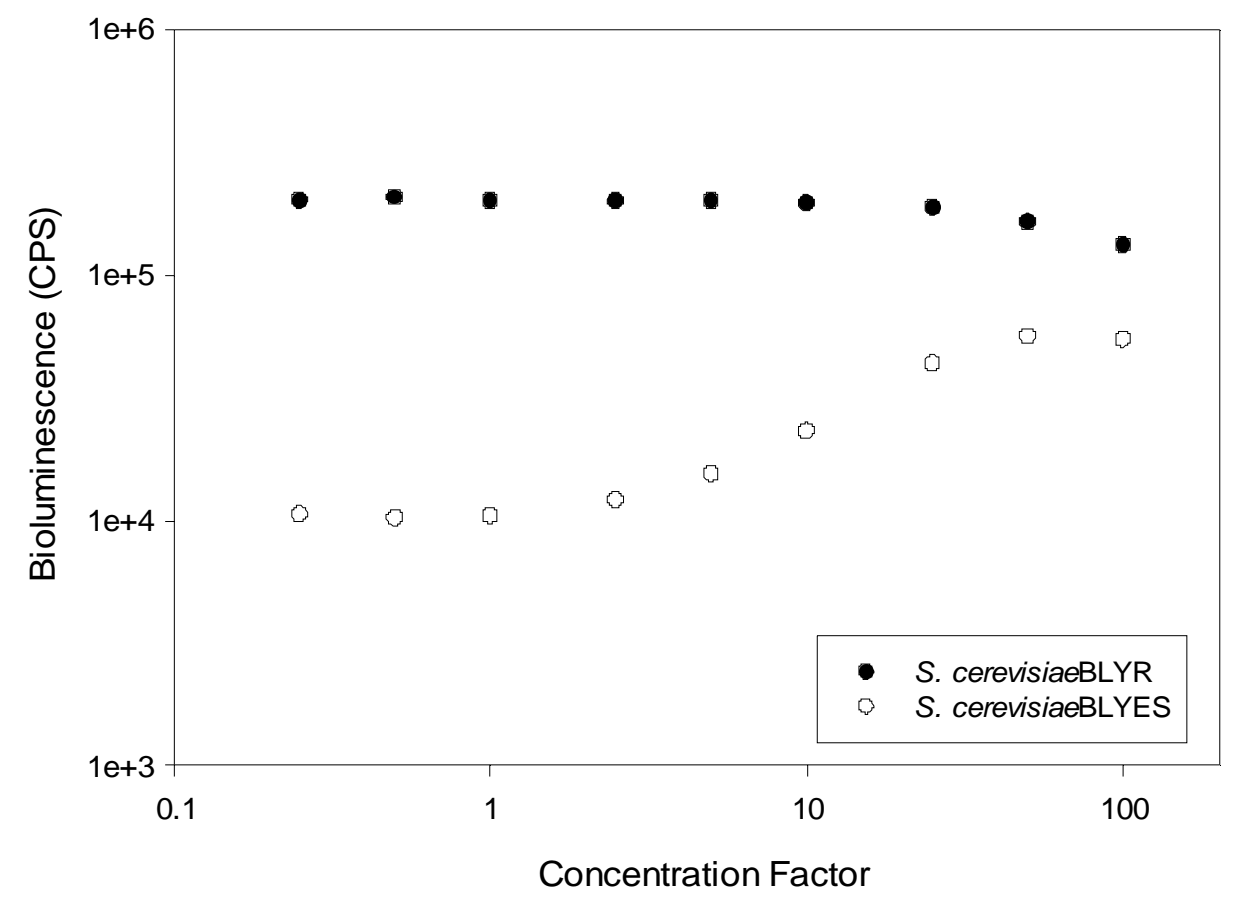

Figura 29 - Curva dose-resposta da amostra $\mathrm{SC}_{3} 2$ (intensidade de bioluminescência versus fator de concentração) $-2^{\mathrm{a}}$ replicata da amostra de São Carlos com menores tempo de contato concentração de ozônio. 


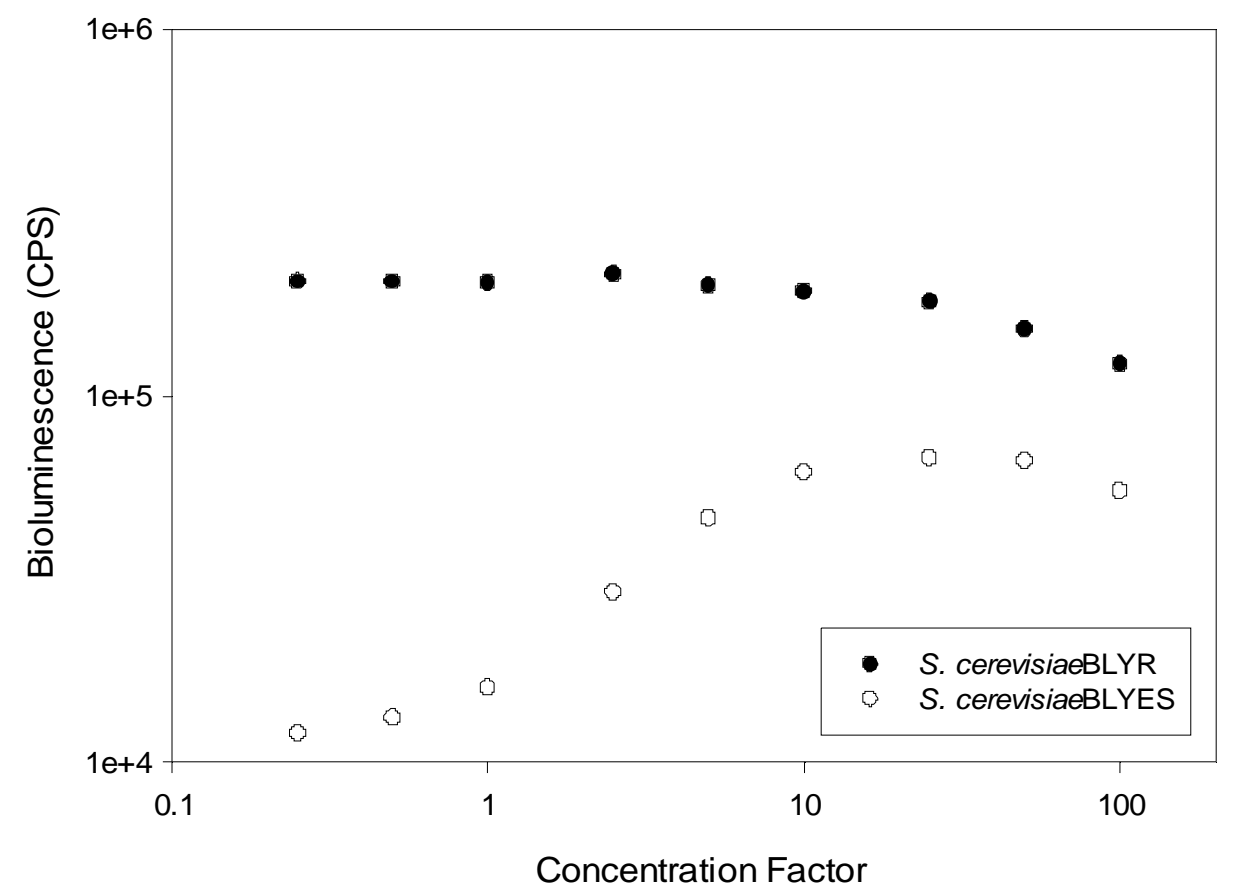

Figura 30 - Curva dose-resposta da amostra $\mathrm{SC} \mathrm{O}_{3} 3$ (intensidade de bioluminescência versus fator de concentração) $-1^{\text {a }}$ replicata da amostra de São Carlos com maiores tempo de contato concentração de ozônio.

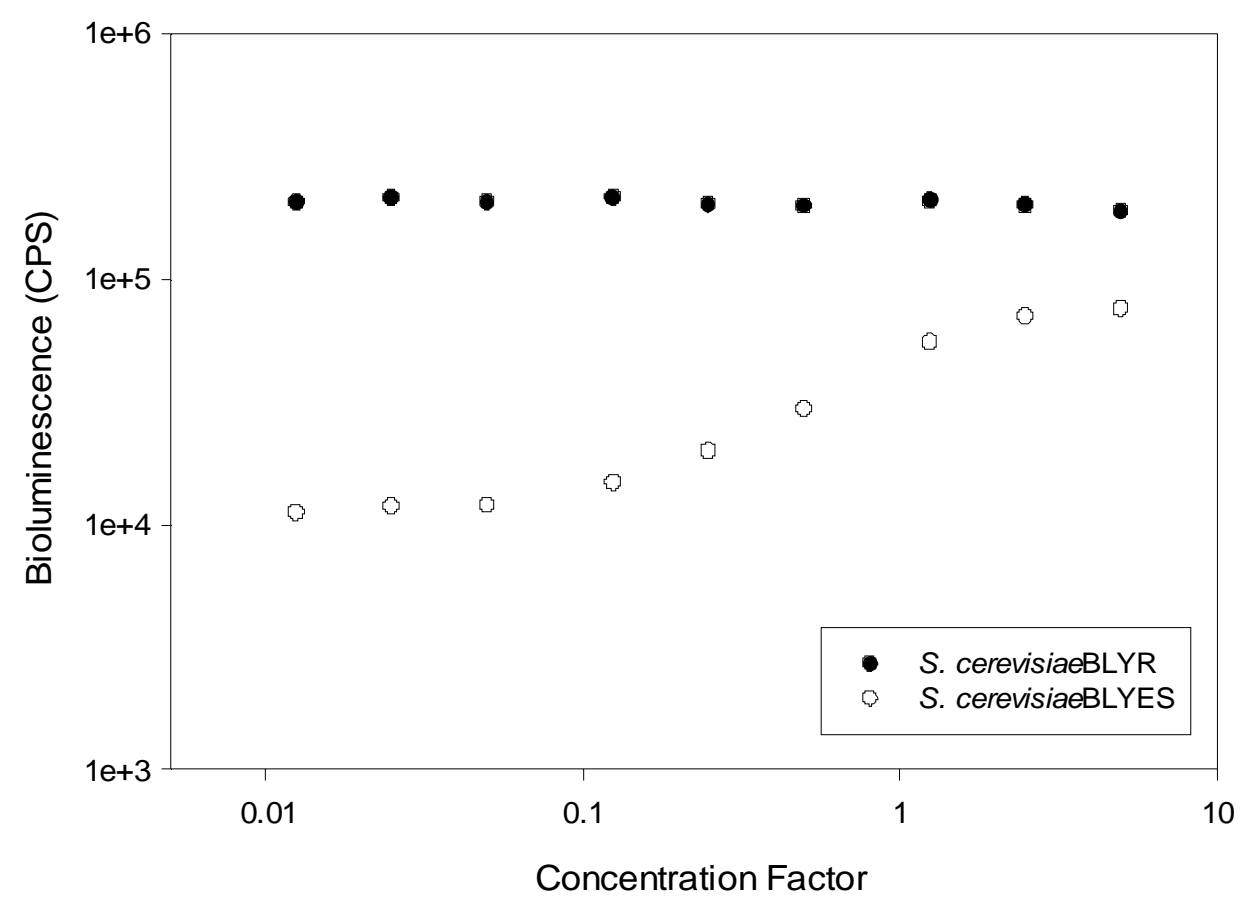

Figura 31 - Curva dose-resposta da amostra $\mathrm{SC} \mathrm{O}_{3} 4$ (intensidade de bioluminescência versus fator de concentração) $-2^{\mathrm{a}}$ replicata da amostra de São Carlos com maiores tempo de contato concentração de ozônio. 
Com base nas curvas de dose-resposta dos ensaios, por meio do programa SigmaPlot ${ }^{\circledR}$, foram obtidos os pontos máximos, mínimos e médios do padrão de E2, calculou-se o logaritmo do ponto médio, a equação da reta (bem como seus coeficientes angular e linear), seu coeficiente de correlação e os valores de $\mathrm{CE}_{50}$ e concentração molar (expressa em mol L ${ }^{-1}$ ) e em massa (expressa em ngE2equiv $\mathrm{L}^{-1}$ ). As amostras 1 e 2, bem como as 3 e 4, representam as replicatas dos ensaios. A partir dos resultados obtidos, foi possível realizar um tratamento estatístico, com a expressão da média, desvio padrão e desvio padrão relativo da atividade estrogênica residual, representada na Tabela 9, e da remoção da atividade estrogênica, representada na Tabela 10.

Tabela 9 - Atividade estrogênica residual das amostras de água filtrada das ETA de São Carlos, contaminadas com 6.000 ngE2equiv $\mathrm{L}^{-1}$ e submetidas à ozonização

\begin{tabular}{|c|c|c|c|c|c|}
\hline Ensaio & $\begin{array}{c}\text { Ozônio } \\
\text { Consumido } \\
\text { (mg) }\end{array}$ & $\begin{array}{c}\text { Atividade } \\
\text { Estrogênica } \\
\text { Residual } \\
\text { (ngE2equiv } \mathbf{L}^{-1} \text { ) }\end{array}$ & $\begin{array}{c}\text { Atividade } \\
\text { Estrogênica } \\
\text { Residual Média } \\
\left(\text { ngE2equiv L }{ }^{-1} \text { ) }\right.\end{array}$ & $\begin{array}{l}\text { Desvio Padrão } \\
\left(\text { ngE2equiv } \mathbf{L}^{-1} \text { ) }\right.\end{array}$ & $\begin{array}{c}\text { Desvio } \\
\text { Padrão } \\
\text { Relativo } \\
(\%)\end{array}$ \\
\hline Br. $\mathrm{SC} \mathrm{O}_{3}$ & - & $<0,10$ & - & - & - \\
\hline $\mathrm{SC} \mathrm{O}_{3} 1$ & 3,39 & 13,0 & \multirow{2}{*}{8,0} & \multirow{2}{*}{7,0} & \multirow{2}{*}{$87 \%$} \\
\hline $\mathrm{SC} \mathrm{O}_{3} 2$ & 3,54 & 3,1 & & & \\
\hline $\mathrm{SC} \mathrm{O}_{3} 3$ & 0,69 & 17,0 & \multirow{2}{*}{56,1} & \multirow{2}{*}{55,3} & \multirow{2}{*}{$99 \%$} \\
\hline $\mathrm{SC} \mathrm{O}_{3} 4$ & 0,54 & 95,2 & & & \\
\hline
\end{tabular}


Tabela 10 - Remoção da Atividade estrogênica das amostras de água filtrada das ETA de São Carlos, contaminadas com 6.000 ngE2equiv $L^{-1}$ e submetidas à ozonização

\begin{tabular}{ccccc}
\hline Ensaio & $\begin{array}{c}\text { Atividade } \\
\text { Estrogênica } \\
\text { Removida }\end{array}$ & $\begin{array}{c}\text { Remoção da } \\
\text { Atividade } \\
(\text { ngE2equiv L }\end{array}$ & $\begin{array}{c}\text { Remoção Média } \\
\text { da Atividade }\end{array}$ & $\begin{array}{c}\text { Desvio Padrão } \\
\text { Relativo (\%) }\end{array}$ \\
$\mathrm{SC} \mathrm{O}_{3} 1$ & 5987 & $99,78 \%$ & & \\
$\mathrm{SC} \mathrm{O}_{3} 2$ & 5997 & $99,95 \%$ & $99,87 \%$ & $0,12 \%$ \\
$\mathrm{SC} \mathrm{O}_{3} 3$ & 5983 & $99,72 \%$ & & \\
$\mathrm{SC} \mathrm{O}_{3} 4$ & 5905 & $98,41 \%$ & $99,07 \%$ & $0,92 \%$ \\
\hline
\end{tabular}

Dos resultados, verifica-se que as amostras que tiveram maior consumo de ozônio tiveram maiores remoções da atividade estrogênica. Constatou-se também que menores desvios padrões são observados quando se analisa as remoções dos contaminantes, as quais, em média, foram superiores a $99,4 \%$.

Depreende-se dos resultados obtidos que o ozônio consumido pelas amostras é próximo ao aplicado, sendo que nas replicatas $\mathrm{SC} \mathrm{O}_{3} 1$ e 2 foi aplicado, teoricamente, 4,0 mg de $\mathrm{O}_{3}$, enquanto que nas $\mathrm{SC}_{3} 3$ e 4, 1,0 $\mathrm{mg}$ de $\mathrm{O}_{3}$. O ozônio consumido pelas amostras pode ser menor do que o calculado, já que o mesmo foi quantificado mediante a titulação as solução de iodeto de potássio presente no off gas, e o ozônio residual da amostra, havendo a possibilidade de parte do ozônio não ter reagido e ter ficado em partes do aparato montado, como no head space da coluna de contato, ou até uma demanda por agente oxidante por parte da matriz, como observado nos ensaios de cloração.

Não ocorreu boa correlação nos valores observados de atividade estrogênica residual nas replicatas. Isso pode ter ocorrido por conta de erros na dosagem de ozônio da amostra, considerando que, para a aplicação desse agente oxidante, foi utilizado equipamento de laboratório com elevada geração de ozônio para as condições dos ensaios (volume da coluna e o tempo de contato), sendo necessário baixo tempo de aplicação de ozônio na amostra e tempo adicional para completar o tempo de contato especificado para cada ensaio. 
Todavia, a cinética de remoção da atividade estrogênica nos ensaios de oxidação por ozônio pode ser considerada elevada, tendo em vista a verificação de uma remoção mínima de $98,41 \%$ da atividade estrogênica de uma amostra com elevada concentração inicial de $17 \beta$ estradiol (de $6.000 \mathrm{ng} \mathrm{L}^{-1}$ ), com aplicação de $0,5 \mathrm{mg} \mathrm{L}^{-1}$ de $\mathrm{O}_{3}$ e em um tempo de contato de $10 \mathrm{~min}$.

\subsubsection{Amostras das ETAs 3 e 4 de Campinas}

As Figuras 32 a 36 representam as curvas dose-resposta de atividade estrogênica do branco (água coletada na saída do filtro) e das amostras tratadas com ozônio após contaminação por $17 \beta$-estradiol.

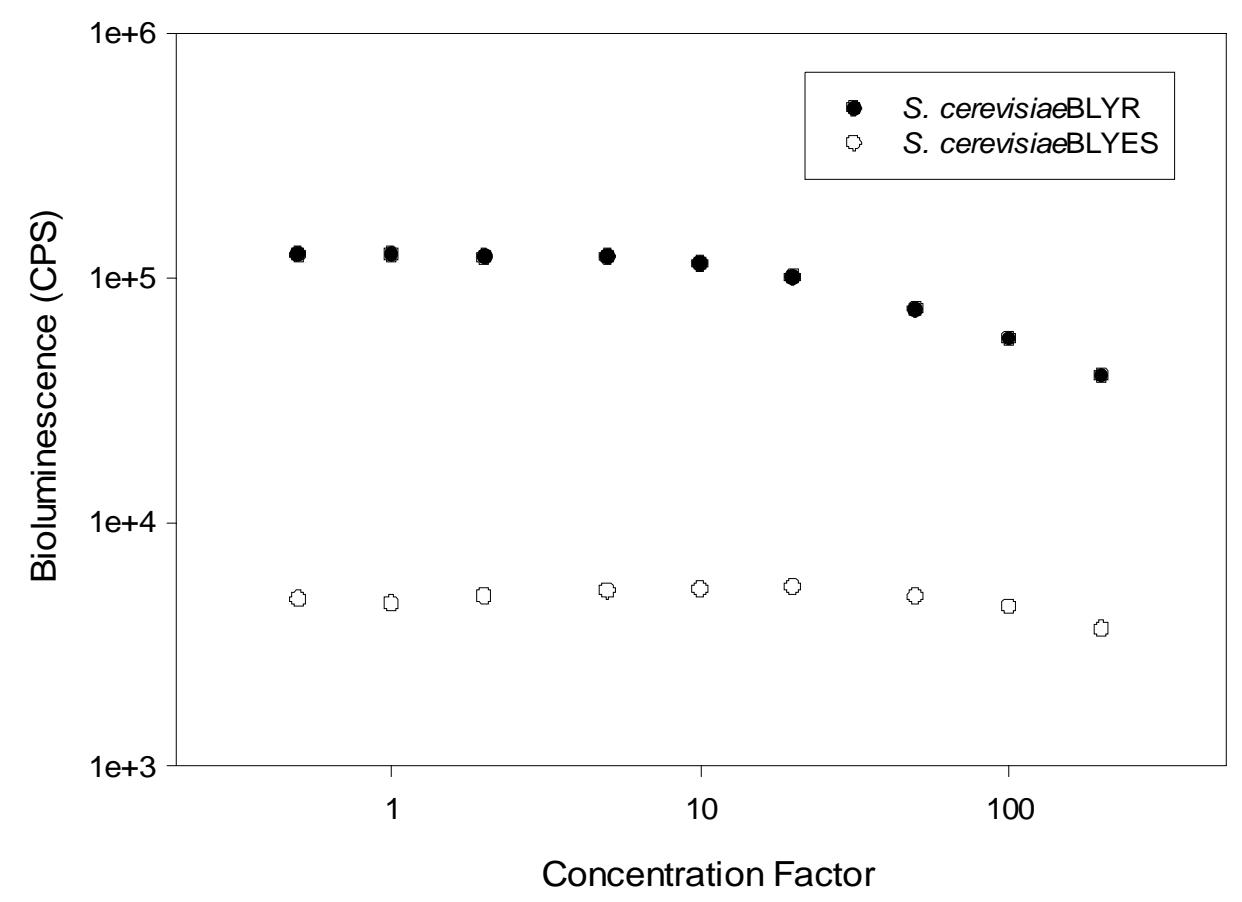

Figura 32 - Curva dose-resposta para o Branco da amostra $\mathrm{CPS} \mathrm{O}_{3}$ (intensidade de bioluminescência versus fator de concentração) para análise de amostras de Campinas tratadas com ozônio. 


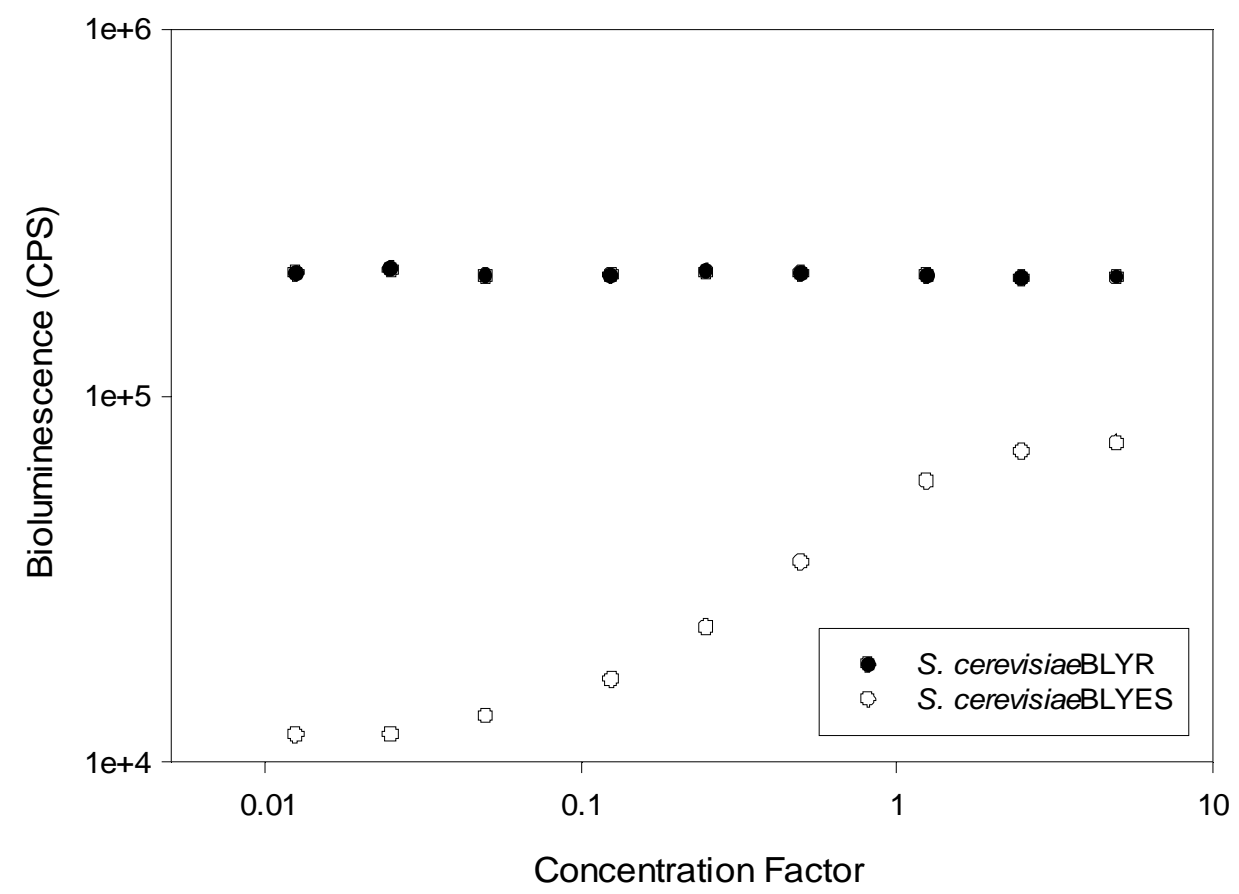

Figura 33 - Curva dose-resposta da amostra CPS O 1 (intensidade de bioluminescência versus fator de concentração) - $1^{\mathrm{a}}$ replicata da amostra de Campinas com menores tempo de contato concentração de ozônio.

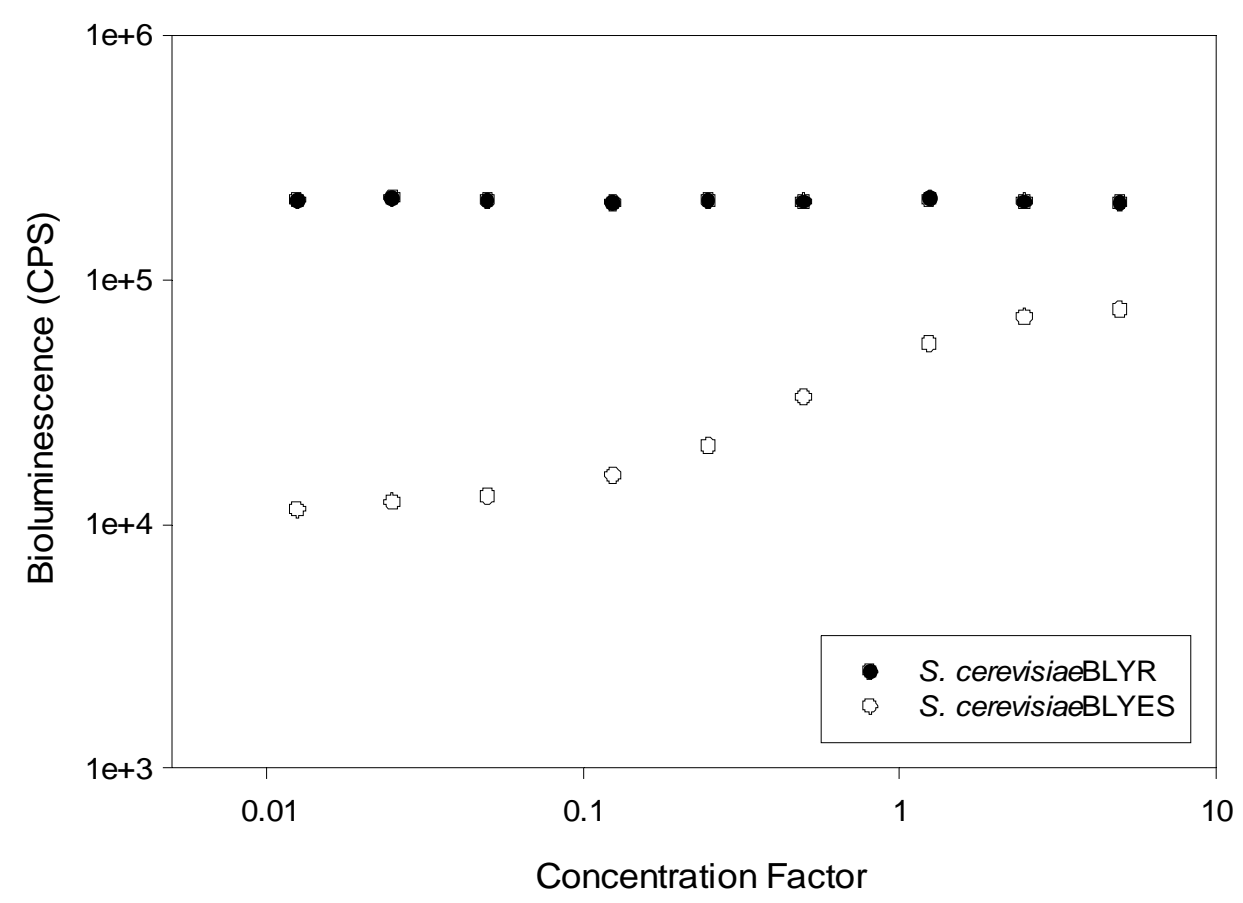

Figura 34 - Curva dose-resposta da amostra CPS O 2 (intensidade de bioluminescência versus fator de concentração) $-2^{\mathrm{a}}$ replicata da amostra de Campinas com menores tempo de contato concentração de ozônio. 


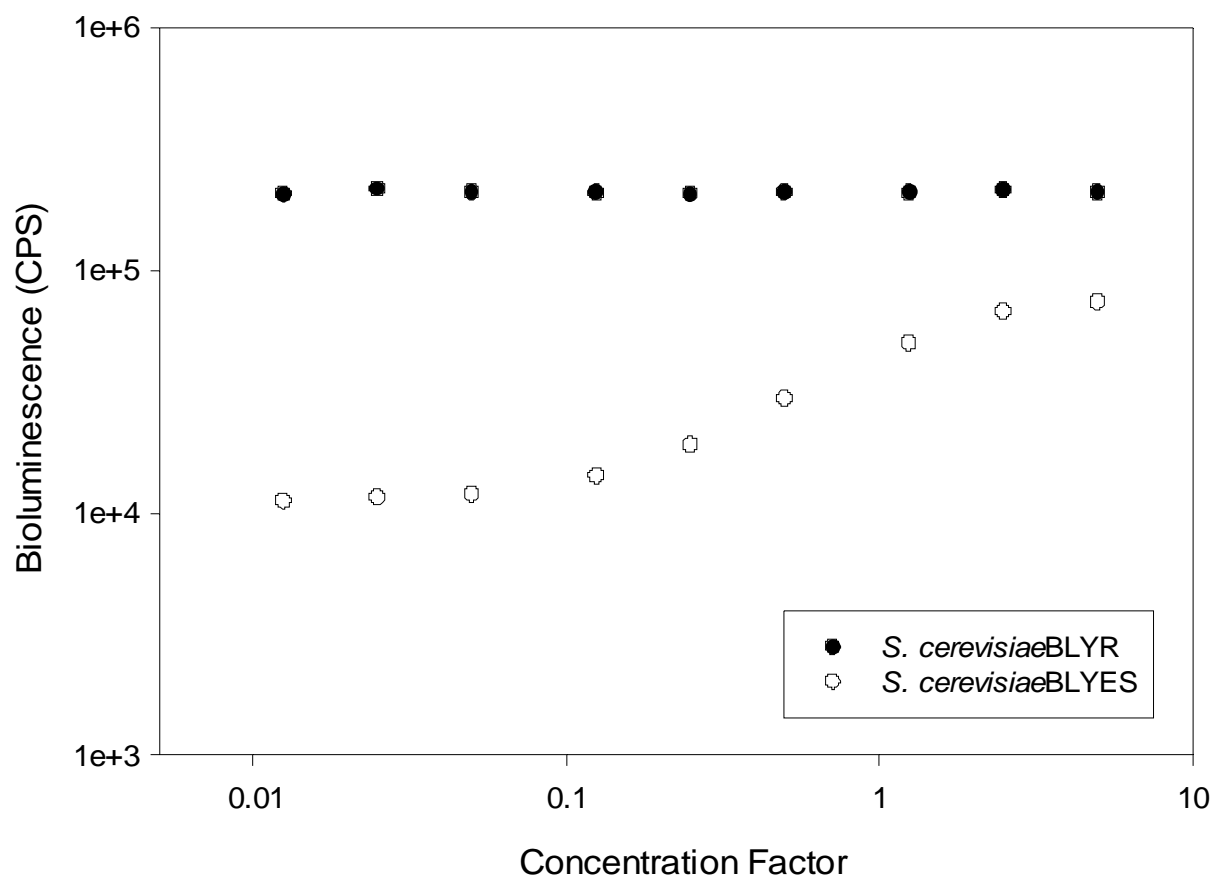

Figura 35 - Curva dose-resposta da amostra $\mathrm{CPS} \mathrm{O}_{3} 3$ (intensidade de bioluminescência versus fator de concentração) $-1^{a}$ replicata da amostra de Campinas com maiores tempo de contato concentração de ozônio.

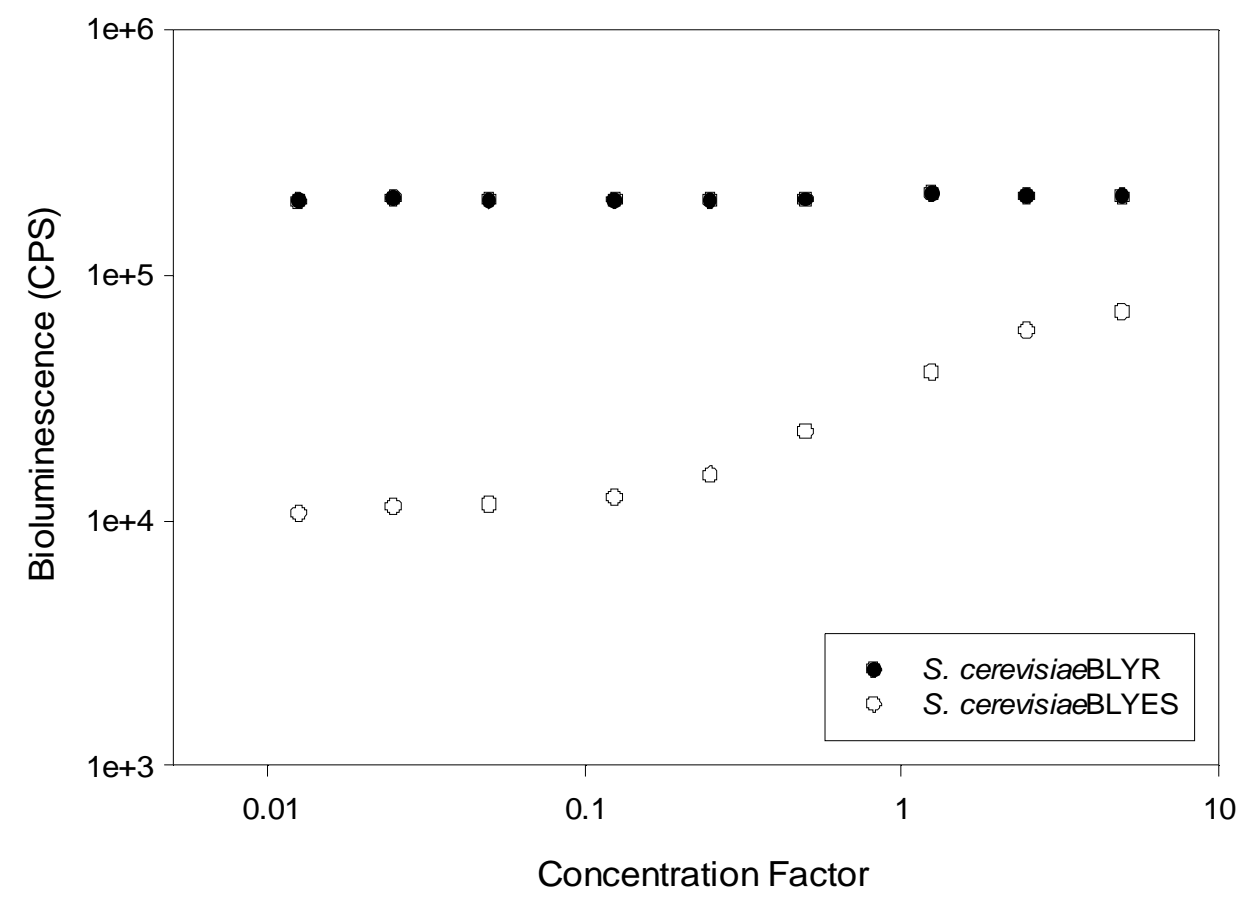

Figura 36 - Curva dose-resposta da amostra CPS O 4 (intensidade de bioluminescência versus fator de concentração) $-2^{a}$ replicata da amostra de Campinas com maiores tempo de contato concentração de ozônio. 
Com base nas curvas de dose-resposta dos ensaios, por meio do programa SigmaPlot ${ }^{\circledR}$, foram obtidos os pontos máximos, mínimos e médios do padrão de E2, calculou o logaritmo do ponto médio, a equação da reta (bem como seus coeficientes angular e linear), seu coeficiente de correlação e os valores de $\mathrm{CE}_{50}$ e concentração molar (expressa em mol L ${ }^{-1}$ ) e em massa (expressa em ngE2equiv $\mathrm{L}^{-1}$ ). As amostras 1 e 2, bem como as 3 e 4 , representam as replicatas dos ensaios. A partir dos resultados obtidos, foi possível realizar um tratamento estatístico, com a expressão da média, desvio padrão e desvio padrão relativo da atividade estrogênica residual, representada na Tabela 11, e da remoção da atividade estrogênica, representada na Tabela 12 .

Tabela 11 - Atividade estrogênica residual das amostras de água filtrada das ETAs 3 e 4 de Campinas, contaminadas com 6.000 ngE2equiv $\mathrm{L}^{-1}$ e submetidas à ozonização

\begin{tabular}{|c|c|c|c|c|c|}
\hline Ensaio & $\begin{array}{c}\text { Ozônio } \\
\text { Consumido } \\
\text { (mg) }\end{array}$ & $\begin{array}{c}\text { Atividade } \\
\text { Estrogênica } \\
\text { Residual } \\
\text { (ngE2equiv L }{ }^{-1} \text { ) }\end{array}$ & $\begin{array}{c}\text { Atividade } \\
\text { Estrogênica } \\
\text { Residual Média } \\
\text { (ngE2equiv } \mathbf{L}^{-1} \text { ) }\end{array}$ & $\begin{array}{l}\text { Desvio Padrão } \\
\left(\text { ngE2equiv L }{ }^{-1}\right)\end{array}$ & $\begin{array}{c}\text { Desvio } \\
\text { Padrão } \\
\text { Relativo } \\
(\%)\end{array}$ \\
\hline Br. CPS $\mathrm{O}_{3}$ & - & $<0,10$ & - & - & - \\
\hline $\begin{array}{l}\mathrm{CPS} \mathrm{O}_{3} 1 \\
\mathrm{CPS} \mathrm{O}_{3} 2\end{array}$ & $\begin{array}{l}2,47 \\
1,71\end{array}$ & $\begin{array}{l}115 \\
99,2\end{array}$ & 107 & 11,2 & $10 \%$ \\
\hline $\begin{array}{l}\mathrm{CPS} \mathrm{O}_{3} 3 \\
\mathrm{CPS} \mathrm{O}_{3} 4\end{array}$ & $\begin{array}{l}0,23 \\
0,23\end{array}$ & $\begin{array}{l}84,5 \\
58,0\end{array}$ & 71,3 & 18,7 & $26 \%$ \\
\hline
\end{tabular}


Tabela 12 - Remoção da Atividade estrogênica das amostras de água filtrada das ETAs 3 e 4 de Campinas, contaminadas com 6.000 ngE2equiv $L^{-1}$ e submetidas à ozonização

\begin{tabular}{ccccc}
\hline Ensaio & $\begin{array}{c}\text { Atividade } \\
\text { Estrogênica } \\
\text { Removida }\end{array}$ & $\begin{array}{c}\text { Remoção da } \\
\text { Atividade } \\
(\text { ngE2equiv L }\end{array}$ & $\begin{array}{c}\text { Remoção Média } \\
\text { da Atividade }\end{array}$ & $\begin{array}{c}\text { Desvio Padrão } \\
\text { Relativo (\%) }\end{array}$ \\
$\mathrm{CPS} \mathrm{O}_{3} 1$ & 5885 & $98,08 \%$ & & \\
$\mathrm{CPS} \mathrm{O}_{3} 2$ & 5901 & $98,35 \%$ & $98,22 \%$ & $0,19 \%$ \\
$\mathrm{CPS} \mathrm{O}_{3} 3$ & 5916 & $98,59 \%$ & & \\
$\mathrm{CPS} \mathrm{O}_{3} 4$ & 5942 & $99,03 \%$ & $98,81 \%$ & $0,31 \%$ \\
\hline
\end{tabular}

Dos resultados, verifica-se que, diferentemente do observado na matriz proveniente de São Carlos, as amostras que apresentaram menor consumo de ozônio tiveram maiores remoções da atividade estrogênica. Constatou-se também que menores desvios padrões são observados quando se analisa as remoções dos contaminantes, as quais, em média, foram superiores a $98,5 \%$.

Depreende-se dos resultados obtidos que o ozônio consumido pelas amostras é bem abaixo do observado nas amostras provenientes da ETA de São Carlos, sendo que o aplicado nas replicatas CPS $\mathrm{O}_{3} 1$ e 2 foi, teoricamente, 4,0 $\mathrm{mg}$ de $\mathrm{O}_{3}$, enquanto que nas $\mathrm{CPS} \mathrm{O}_{3} 3$ e 4 , $1,0 \mathrm{mg}$ de $\mathrm{O}_{3}$. $\mathrm{O}$ ozônio consumido pela amostra pode ser menor do que o calculado, já que o mesmo foi quantificado mediante a titulação as solução de iodeto de potássio presente no off gas, e o ozônio residual da amostra, havendo a possibilidade de parte do ozônio não ter reagido e ter ficado em partes do aparato montado, como no head space da coluna de contato.

Não ocorreu boa correlação nos valores observados de atividade estrogênica residual nas replicatas pelos mesmos motivos discutidos no item 5.5.1.

O fato de ter sido observado uma remoção da atividade estrogênica maior nas replicatas conduzidas com aplicação de $0,5 \mathrm{mg} \mathrm{L}^{-1}$ de ozônio com um tempo de contato de 10 min pode ter ocorrido devido a permanência desse gás na coluna de contato mesmo após a sua 
limpeza entre um ensaio e outro, havendo uma transferência do agente oxidante de um experimento para o outro.

Todavia, a cinética de remoção da atividade estrogênica nos ensaios de oxidação por ozônio pode ser considerada elevada, tendo em vista a verificação de uma remoção mínima de 98,59\% da atividade estrogênica de uma amostra com elevada concentração inicial de 17 $\beta$ estradiol (de $6.000 \mathrm{ng} \mathrm{L}^{-1}$ ), com aplicação de $0,5 \mathrm{mg} \mathrm{L}^{-1}$ de $\mathrm{O}_{3}$ e em um tempo de contato de $10 \mathrm{~min}$.

\subsection{Comparação dos resultados de remoção da atividade estrogênica com a utilização de cloro e ozônio}

Assim como observado por Pereira (2011), o ozônio se mostrou um oxidante mais eficiente na remoção do $17 \beta$-estradiol (sendo no presente trabalho avaliado em atividade estrogênica por teste BLYES) em relação ao cloro para dosagens semelhantes em tempos de contato iguais. A demanda por agente oxidante pela matriz de São Carlos, a presença de cloro total nas amostras de Campinas submetida à oxidação por cloro e a produção inconstante do gerador de ozônio impossibilitaram a realização de ensaios com concentrações de agentes oxidantes com exatidão.

No entanto, comparando-se todos os resultados obtidos nas desinfecções por cloro e por ozônio nas duas matrizes e nas diferentes concentrações e tempos de contato, verificou-se que, enquanto o cloro apresentou uma taxa de remoção da atividade estrogênica de 34,5\% (SC $\mathrm{Cl}_{2}$ 1) a $95,5 \%\left(\mathrm{SC} \mathrm{Cl}_{2} 4\right)$, o ozônio removeu de $98,1 \%\left(\mathrm{CPS} \mathrm{O}_{3} 1\right)$ a 99,95\% ( $\left.\mathrm{SC} \mathrm{O}_{3} 2\right)$ desse parâmetro de controle.

Comparando-se os ensaios de oxidação por 10 minutos, realizados nas matrizes de água de Campinas e de São Carlos, verifica-se que o máximo de remoção da atividade estrogênica obtido com a utilização de cloro foi de 70,8\% (CPS $\mathrm{Cl}_{2}$ 1), enquanto que com o ozônio obteve-se remoção de até 99,72\% ( $\left.\mathrm{SC} \mathrm{O}_{3} 3\right)$ Disso, desprende-se que a cinética de remoção da atividade estrogênica causada por $17 \beta$-estradiol, sobretudo nos 10 primeiros minutos de contato é maior quando utiliza-se o ozônio como oxidante. 
Tal discrepância de valores, em números absolutos, não foi observada nos ensaios com tempos de contato de 30 minutos, onde se verificou que a oxidação por cloro removeu até 95,5\% ( $\left.\mathrm{SC} \mathrm{Cl}_{2} 4\right)$ da atividade estrogênica, enquanto que o ozônio removeu até 99,95\% (SC $\mathrm{O}_{3}$ 2). De fato, à medida que a concentração de $17 \beta$-estradiol é reduzida na amostra, a cinética de reação torna-se substancialmente mais lenta. Esse resultado fora observado, também, por Pereira (2011). 


\section{CONCLUSÕES}

Os testes por BLYES realizados nas águas das saídas dos filtros das ETAs 3 e 4 da SANASA de Campinas - SP e na ETA do SAAE de São Carlos - SP (branco das amostras) apontou a presença de desregulador(es) endócrino(s) na amostra coletada no mês de janeiro/2013 no município de São Carlos $\left(0,19\right.$ ngE2equiv $\left.\mathrm{L}^{-1}\right)$, valor bem próximo do limite de quantificação do método $\left(0,10 \mathrm{ngE2equiv} \mathrm{L}^{-1}\right)$. Essa única análise, sem replicatas, não é suficiente para indicar a presença de estrogenicidade no manancial.

$\mathrm{Na}$ estação de Campinas, não foi detectada atividade estrogênica nas duas campanhas amostrais realizadas. Foi detectada atividade estrogênica no rio Atibaia, no trecho onde há a captação de água das ETAs 3 e 4 (JARDIM et al., 2012; RAIMUNDO, 2011; MONTAGNER et al., 2011). No entanto, a pré-cloração da água a ser tratada na estação, associado ao tempo de contato do agente oxidante com a amostra e com as baixas concentrações de atividade estrogênica (variando no manancial de 0,06 a 6,54 ngE2equiv $\mathrm{L}^{-1}$ ) foi eficiente, nessas duas campanhas, para a remoção da atividade estrogênica até valores inferiores ao limite de quantificação do bioensaio $\left(0,10 \mathrm{ngE2equiv} \mathrm{L}^{-1}\right)$.

O BLYES apresentou-se como uma ferramenta, que pode ser empregada na avaliação rotineira da qualidade da água distribuída à população no diagnóstico de potencial interferência endócrina.

Os resultados apresentados neste trabalho demonstram que a oxidação por ozônio se mostrou mais eficiente do que a por cloro para a remoção da atividade estrogênica causada, única e exclusivamente, pelo 17 $\beta$-estradiol, empregando-se dosagens e tempos de contatos semelhantes para uma dosagem inicial desse hormônio relativamente alta $\left(6.000 \mathrm{ng} \mathrm{L}^{-1}\right)$. Todavia, em todos os ensaios a concentração final da atividade estrogênica permaneceu acima do limite de quantificação desses hormônio, indicando que a remoção não foi completa, mesmo em condições favoráveis, isto é, matriz limpa, com padrões de potabilidade para os parâmetros físico-químicos. Este fato confirma que o composto em questão é de difícil degradação e que possui uma cinética de remoção lenta, podendo seus subprodutos apresentarem atividade estrogênica, sendo difícil alcançar sua completa eliminação a níveis que não comprometam a potabilidade da água. 


\section{SUGESTÕES}

Recomenda-se a associação de técnicas analíticas, com limites de quantificação na ordem de decimal ou unidade de nanograma por litro, com bioensaios in vitro, a fim de correlacionar a atividade estrogênica detectada com a presença do contaminante ou de seus subprodutos.

Sugere-se a redução estequiométrica do cloro presente na amostra de água de Campinas, a fim de se comparar de maneira mais sistemática os efeitos das matrizes de água da ETA do Centro do SAAE de São Carlos e das ETAs 3 e 4 da SANASA de Campinas, para os ensaios com cloração da amostra.

Considerando o indicativo de presença de contaminação por interferentes endócrinos no efluente dos filtros na ETA do Centro de São Carlos, recomenda-se o monitoramento da atividade estrogênica dos mananciais que abastecem esta cidade. Salienta-se que não há qualquer tipo de norma ou legislação que regule o lançamento de efluentes ou classifique mananciais quanto à atividade estrogênica no Brasil.

Para avaliação da real remoção de atividade estrogênica, sugere-se o monitoramento de mananciais, para a identificação e a contaminação de amostras sintéticas controladas com diversos interferentes endócrinos, seguido da realização de novos ensaios de oxidação com desinfetantes de uso comercial em estações de tratamento de água convencionais. 


\section{REFERÊNCIAS BIBLIOGRÁFICAS}

AHRER, W., SCHERWENK, E., BUCHBERGER, W., "Determination of Drug Residues in Water by the Combination of Liquid Chromatography or Capillary Electrophoresis With Electrospray Mass Spectrometry" Journal of Chromatography A, v. 910, pp. 69-78, 2001.

ALMEIDA, E., ASSALIN, M. R., ROSA, M. A., DURAN, N. "Tratamento de Efluentes Industriais por Processos Oxidativos na Presença de Ozônio", Química Nova, v. 27, n. 5, pp. 818-824, 2004.

ANDREOZZI, R., CAPRIO, V., INSOLA, A., et al., 1999 “Advanced Oxidation Processes (AOP) for Water Purification and Recovery” Catalysis Today, v. 53, pp. 51-59.

APHA - American Public Health Association, AWWA - American Water Works Association, WEF - Water Environment Federation. Standard Methods for the Examination of Water and Wastewater. 22th ed. Washington: APHA, 2012

BEAUSSE, J., "Selected Drugs in Solid Matrices: A Review of Environmental Determination, Occurrence and Properties of Principal Substances” Trends in Analytical Chemistry, v. 23 (10-11), pp. 753-761, 2004.

BEHNISCH, P. A., FUJII, K., SHIOZAKI, K., et al., "Estrogenic and Dioxin-Like Potency in each step of a Controlled Landfill Leachate Treatment Plant in Japan" Chemosphere, v. 43, pp. 977-984, 2001.

BELFROID, A. C., VAN DER HORST, A., VETHAAK, A. D. et al., "Analysis and Occurrence of Estrogenic Hormones and their Glucuronides in Surface Water and Waste Water in The Netherlands" The Science Total Environment, v. 225, pp.101-108, 1999.

BERGAMASCO A.M.D., 2010. Emprego de Bioensaios para Atividade Estrogênica Água para Consumo Humano e Mananciais do Estado de São Paulo; Dissertação de mestrado; Departamento de Toxicologia e Análises Toxicológicas, Faculdade de Ciências Farmacêuticas; Universidade de São Paulo; 90 pp. 
BILA, D. M., 2005. Degradação e Remoção da Atividade Estrogênica do Desregulador Endócrino 17ß-Estradiol pelo Processo de Ozonização, Tese de Doutorado, UFRJ/COPPE.

BIRKETT, J. W., LESTER, J. N., 2003. Endocrine Disrupters in Wastewater and Sludge Treatment Process, $1^{\circ}$ edição, Lewis Publishers.

BUSER, H.-R., MÜLLER, M. D., THEOBALD, N., 1998a. Occurrence of the Pharmaceutical Drug Clofibric Acid and the Herbicide Mecoprop in Various Swiss Lakes and in the North Sea” Environmental. Science Technology,v. 32, pp. 188-192.

BUSER, H.-R., POIGER, T., MÜLlER, M. D., 1998b. Occurrence and Fate of the Pharmaceutical Drug Diclofenac in Surface Waters: Rapid Photodegradation in a Lake" Environmental Science Technology, v. 32 (22), pp. 3449-3456.

BUSER, H.-R., POIGER, T., MÜLLER, M. D., 1999. Occurrence and Environmental Behavior of the Chiral Pharmaceutical Drug Ibuprofen in Surface Waters and in Wastewater" Environmental Scence Technology, v. 33, pp. 2529-2535.

CAMEL, V., BERMOND, A., 1998. The Use of Ozone and Associated Oxidation Processes in Drinking Water Treatment, Water Research, v. 32(1), pp. 3208- 3222.

CARGOUËT, M., PERDIZ, D., MOUATASSIM-SOUALI, A., et al., 2004. Assessment of River Contamination by Estrogenic Compounds in Paris Area (France), Science of the Total Environment, v. 324 (1-3), pp. 55-66.

CAVALCANTI, J.E.W.A., 2009. Manual de Tratamento de Efluentes Industriais.

CHERNICHARO, C.A.L. et al 2001. Pós-tratamento de Efluentes de Reatores Anaeróbios por Sistemas de Desinfecção; in Pós-tratamento de Efluentes Anaeróbios, PROSAB/FINEP, Belo Horizonte.

CHERUBINI, C., 2002. Secagem e Higienização de Lodo de Esgoto Anaeróbio em Leitos de Secagem através da Solarização. Dissertação, Mestrado, Universidade Federal do Paraná, Curitiba, 128 p. 
CIOCHETTI, D. A., AND R. H. METCALF. 1984. Pasteurization of naturally contaminated water with solar energy. Appl. Environ. Microbiol. 47:223-228.

CLARA, M., STRENN, B., SARACEVIC, E. et al., 2004. Adsorption of Bisphenol-A, 17ßEstradiole and 17 $\alpha$-Ethinylestradiole to Sewage Sludge, Chemosphere, v. 56, pp. 843851.

COMISSÃO EUROPEIA. 1996. European Workshop on the Impact of Endocrine Disrupters on Human Health and Wildlife. Report of the Proceedings, Weybridge, UK, Report EUR 17549.

ELDRIDGE,M; SANSEVERINO, J; UMBUZEIRO, G A; SAYLER, G S, 2011. Analysis of Environmental Samples with Yeast-Based Bioluminescent Bioreporters, Environmental Monitoring, Dr Ema Ekundayo (Ed.), ISBN: 978-953-307-724-6, InTech.

EVANS, F. L., 1972. Ozone in Water and Wastewater Treatment, Ann Arbor Science Publishers, Michigan.

FARRÉ, M., FERRER, I., GINEBREDA, A., et al., 2001. Determination of Drugs in Surface Water and Wastewater Samples by Liquid Chromatography-Mass Spectrometry: Methods and Preliminary Results Including Toxicity Studies with Vibrio fischeri” Journal Chromatography A, v. 938, pp. 187-197.

FERNANDES, F ; ANDRAUS, S; ANDREOLI, C.V., 1996. Eficiência dos processos de desinfecção do lodo da ETE Belém com vista a seu uso agrícola. SANARE, Curitiba, v. 5, n.5, p.46-58.

FERREIRA, A. C. 2001. Monitoramento da Secagem e Desinfecção de Lodo Anaeróbio em Leito de Secagem com Uso de Estufa Plástica e Biogás. Tese, Universidade Federal do Paraná, Curitiba. 97p.

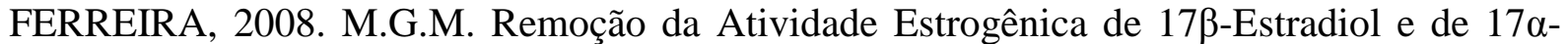
Etinilestradiol pelos Processos de Ozonização e $\mathrm{O}_{3} / \mathrm{H}_{2} \mathrm{O}_{2}$. Tese. Universidade Federal do Rio de Janeiro.192 p. 
FISCHER, N., 2013. Cloração de água com 17ß-estradiol e utilização do teste YES para avaliação de estrogenicidade. 2013. 115 p. Dissertação (Mestrado) - Escola de Engenharia de São Carlos, Universidade de São Paulo, São Carlos.

GENTILI, A., PERRET, D, MARCHESE, S., MASTROPASQUA, R., CURINI R. AND DI CORCIA, A., 2002 Analysis of free estrogens and their conjugates in sewage and river waters by solid-phase extraction then liquid chromatography-electrospray-tandem mass spectrometry. Chromatographia, 56, 25-32.

GLAZE, W. H., 1987. Drinking-Water Treatment With Ozone, Environmental Science Technology, v. 21 (3), pp. 224-230.

GLAZE, W. H., KANG, J.-W., 1989. Advanced Oxidation Processes. Test of a Kinetic Model for the Oxidation of Organic Compounds with Ozone and Hydrogen Peroxide in a Semibatch Reactor, Industrial and Engineering Chemistry Research, v. 28 (11), p. 15801587.

CETESB - Companhia Ambiental do Estado de São Paulo, ANA - Agência Nacional de Águas. Guia nacional de coleta e preservação de amostras: água, sedimento, comunidades aquáticas e efluentes líquidos. Organizadores: Carlos Jesus Brandão ... [et al.]. -- São Paulo: CETESB; Brasília: ANA, 2011.

HU, J. Y. et al., 2003. Products of aqueous chlorination of 17 beta-estradiol and their estrogenic activities. Environmental Science \& Technology, v. 37, n. 24, p. 5665-5670.

JARDIM, W. F. et al., 2012. An integrated approach to evaluate emerging contaminants in drinking water. Separation and Purification Technology, v. 84, p. 3-8.

JORDÃO, E. P. E PESSOA, C. A. 2005. Tratamento de Esgotos Domésticos.

JOYCE, T. M. et al 1995. Inactivation of Fecal Bacteria in Drinking Water by Solar Heating, Applied and environmental microbiology, v2, 1995.p. 399-402.

LESKINEN P., MICHELINI E., PICARD D., KARP M., VIRTA M., 2005. Bioluminescent yeast assay for detecting estrogenic and androgenic activity in different matrices. Chemosphere; 61; p 259. 
LINDSEY, M. E., MEYER, M., THURMAN, E. M., 2001. Analysis of Trace Levels of Sulfonamide and Tetracycline Antimicrobials in Groundwater and Surface Water Using Solid-Phase Extraction and Liquid Chromatography/Mass Spectrometry, Analytical Chemistry v. 73 (19), pp. 4640-4646, 2001.

LOURENÇÃO, J., 2009. Avaliação da resistência de microrganismos patogênicos à desinfecção sequencial com ozônio-radiação ultravioleta e cloro-radiação ultravioleta. Dissertação - Escola da Engenharia de São Carlos, Universidade de São Paulo. São Carlos. 162 p.

MONTAGNER, C. C.; JARDIM, W. F., 2011. Spatial and Seasonal Variations of Pharmaceuticals and Endocrine Disruptors in the Atibaia River, Sao Paulo State (Brazil). Journal of The Brazilian Chemical Society. v. 22, n. 8, p. 1.452-62.

MORAIS, S.M.J de ; ATAÍDES, P.R.V de;GARCIA, D. C. et al. 1996. Uso do lodo de esgoto da Corsan - Santa Maria (RS), comparado com outros substratos orgânicos. Sanare, Curitiba, v. 6, n. 6, p. 44-49.

NAKAMURA, S., SIAN, T. H., DAISHIMA, S., 2001.Determination of estrogens in river water by gas chromatography-negative-ion chemical-ionization mass spectrometry" Journal Chromatography A, v. 919, pp. 275-282.

NAKASHIMA, T., OHKO, Y., TRYK, D. A., et al., 2002. Decomposition of EndocrineDisrupting Chemicals in Water by Use of $\mathrm{TiO} 2$ Photocatalysts Immobilized on Polytetrafluoroethylene Mesh Sheets, Journal of Photochemistry and Photobiology A: Chemistry, v. 151, pp.207-212, 2002.

PASSAMAMI et al. 2002. Higienização de Lodo Utilizando Caleagem e Pasteurização em uma Pequena Estação de Tratamento de Esgoto Combinando Reator UASB e Biofiltro Aerado Submerso. XVIII Congresso Interamericano de Ingenieria Sanitária e Ambiental, Cancun/México.

PEREIRA, R. D. O. 2011. Formação de subprodutos do estrona e 17ß-estradiol na oxidação utilizando cloro e o ozônio em água. 192 p. Tese (Doutorado em Hidráulica e Saneamento). Escola de Engenharia de São Carlos, Universidade de São Paulo, São Carlos. 
RAIMUNDO C.C.M., 2011. Contaminantes emergentes em água tratada e seus mananciais: sazonalidade, remoção e atividade estrogênica. Tese de Doutorado, Universidade Estadual de Campinas, 203 pp.

REIS FILHO, R. W. 2008. Homônios Estrógenos no Rio do Monjolinho -São Carlos -SP: Uma avaliação da Problemática dos Desreguladores Endócrinos ambientais. São Carlos - SP, EESC-USP, tese.

ROUTLEDGE, E. J.; SUMPTER, J. P., 1996. Estrogenic activity of surfactants and some of their degradation products assessed using a recombinant yeast screen. Environmental Toxicology and Chemistry, v. 15, n. 3, p. 241-248.

SÁ, J. P. 2004. Desinfecção de Efluentes Sanitários Tratados pelo Sistema de Lodos Ativados Através do Dióxido de Cloro, Universidade Federal de Santa Catarina.

SANSEVERINO, J., ELDRIDGE M.L., LAYTON A.C., EASTER J.P., YARBROUGH J., SCHULTZ T.W., SAYLER G.S. 2009. Screening of potentially hormonally active chemicals using bioluminescent yeast bioreporters; Toxicol. Sci.; 107; p 122.

SANSEVERINO, J., GUPTA R.K., LAYTON A.C., PATTERSON S.S., RIPP S.A., SAIDAK L., SIMPSON M.L., SCHULTZ T.W., SAYLER G.S. 2005. Use of Saccharomyces cerevisiae BLYES expressing bacterial bioluminescence for rapid, sensitive detection of estrogenic compounds; Appl. Environ. Microbiol.; 71; p 4455.

SILVEIRA, I.C.T., 2004. Cloro e Ozônio aplicados à desinfecção de efluente hospitalar tratado em contatores biológicos rotatórios, com avaliação de efeitos tóxicos em Daphnia similis. Tese de Doutorado, Universidade Federal do Rio Grande do Sul, 173 pp.

SNYDER, S. A. et al., 2003. Pharmaceuticals, personal care products, and endocrine disruptors in water: Implications for the water industry. Environmental Engineering Science, v. 20, n. 5, p. 449-469, 2003.

TERNES, T. A., STUMPF, M., MUELLER, J. et al., 2003. Behavior and Occurrence of Estrogens in Municipal Sewage Treatement Plants - I. Investigations in Germany, Canada and Brazil, The Science Total Environment, v. 225 (1-2), p. 81-90, 1999. 
UNITED STATES. ENVIRONMENTAL PROTECTION AGENCY (USEPA), 1984. Ambient Water Quality Criteria for Chlorine. Washington, DC, 57 p.

VASCONCELOS, Y, 2012. Levedura luminescente - Pesquisadores utilizam microrganismo para detectar hormônio em rios. Revista Fapesp v. 193.

VON GUNTEN, U., Ozonation of Drinking Water: Part I. Oxidation Kinetics and Product Formation. Water Research, v. 37, pp. 1443-1467.

WESTERHOFF, P., YOON, Y., SHYDER, S., WERT, E. 2005. Fate of Endocrine-Disruptor, Pharmaceutical, and Personal Care Product Chemicals during Simulated Drinking Water Treatment Processes, Environmental Science and Technology, v. 39, pp. 66496663.

WINKLER, H., LAWRENCE, J. R., NEU, T. R., 2001. Selective Degradation of Ibuprofen and Clofibric Acid in Two Model River Biofilm Systems, Water Research v. 35 (13), pp. 3197-3205.

XIAO, X. Y., MCCALLEY, D. V., MCEVOY, J. 2001. Analysis of Estrogens in River Water and Effluents Using Solid-Phase Extraction and Gas Chromatography-Negative Chemical Ionisation Mass Spectrometry of the Pentafluorobenzoyl Derivatives", Journal of Chromatography A, v. 932, pp. 195-204.

YING, G. G., KOOKANA, R. S., RU, Y. J. 2002. Occurrence and Fate of Hormones Steroids in the Environment", Environment International, v. 28, pp. 545-551.

YOON, Y., WESTERHOFF, P., YOON, J., SNYDER, S. A. 2004. Removal of 17ß-Estradiol and Fluoranthene by Nanofiltration and Ultrafiltration", Journal of Environmental Engineering, v. 130, n. 12, pp. 1460-1467.

ZHANG, Y., ZHOU, J. L. 2005. Removal of Estrone and 17ß-Estradiol from Water by Adsorption", Water Research, v. 39, pp. 3991-4003.

ZORITAA, S.; MARTENSSONB, L.; MATHIASSONA, L., 2009. Occurrence and Removal of Pharmaceuticals in a Municipal Sewage Treatment System in the South of Sweden, Science of the Total Environment 407, 2760-2770. 